\title{
RESILIENCE IN KENYA
}

Impact evaluation of the 'Building Resilience in the Arid and Semi-Arid Lands of Northern Kenya' project

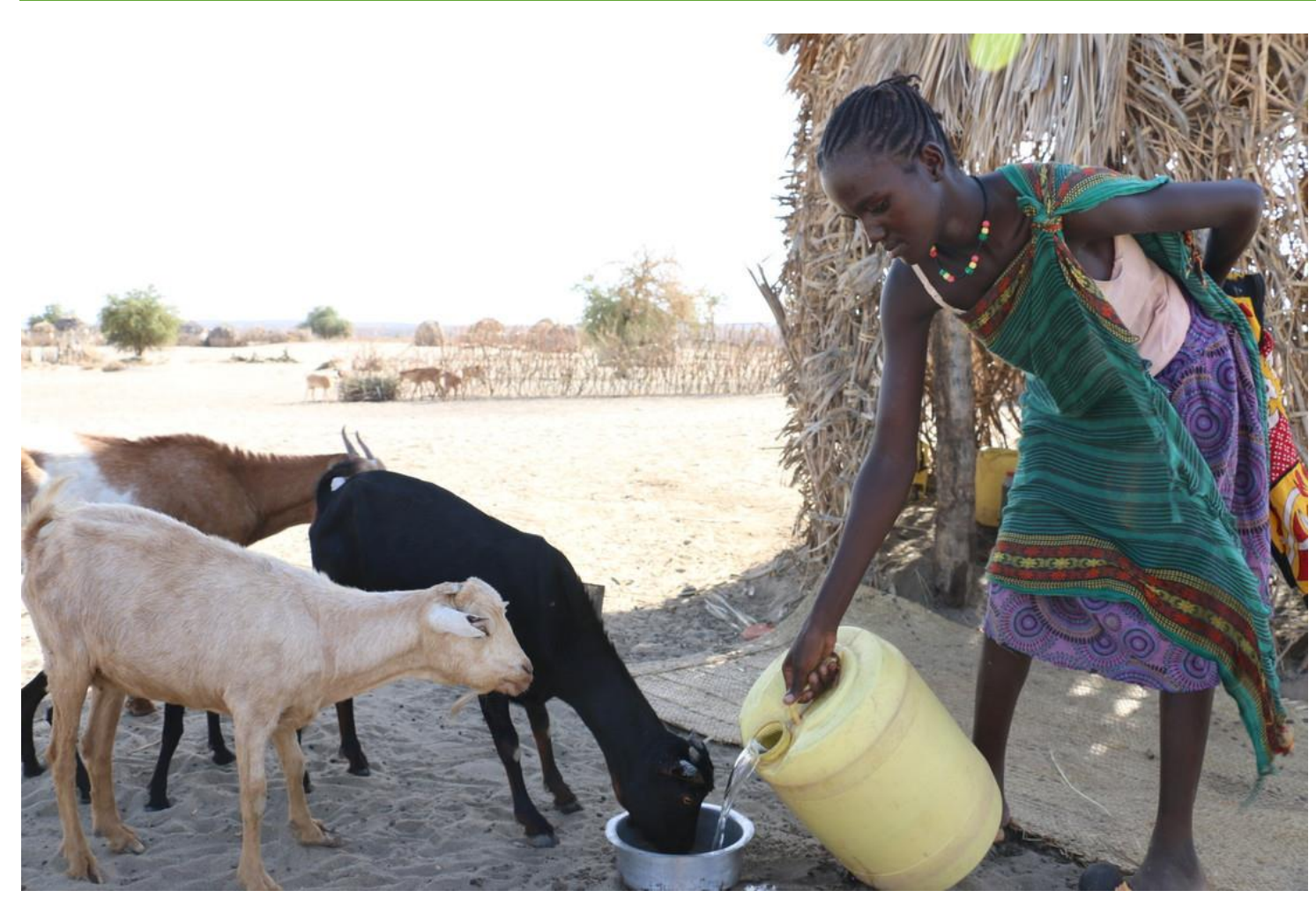

Photo: Jennifer Arot watering her goats with clean water from the Oxfam-supported water kiosk in Nasechabuin, Turkana. Credit: Joyce Kabue/Oxfam

\section{JONATHAN LAIN and DAVID BISHOP}

\section{OXFAM GB}




\section{ACKNOWLEDGEMENTS}

We would like to thank the staff of the partner organizations and of Oxfam in Kenya for their support in carrying out this Effectiveness Review. Particular thanks are due to Emmanuel Kinvunga for his intensive support on the fieldwork, as well as Blandina Bobson, Daphne Callies, Ogle Abdirashid Dubow and Rose Tino Otim for providing the evaluation team with very detailed project information. Thanks are also due to Violah Sugut and Gerald Musundi of Ipsos Kenya for their excellent leadership of the survey process. 


\section{CONTENTS}

Executive Summary

$\begin{array}{lll}1 & \text { Introduction } & 10\end{array}$

2 Project description $\quad 12$

$\begin{array}{lll}3 & \text { Evaluation design } & 17\end{array}$

4 Data 19

5 Measuring Resilience in Kenya 25

6 Results 29

7 Conclusions $\quad 52$ 


\section{EXECUTIVE SUMMARY}

Oxfam GB's Global Performance Framework is part of the organization's effort to better understand and communicate its effectiveness, as well as enhance learning across the organization. Under this Framework, a small number of completed or mature projects are selected at random each year for an evaluation of their impact, known as an 'Effectiveness Review'. These reviews focus on the extent to which a project has promoted change in relation to relevant Oxfam GB global outcome indicators.

During the 2016/17 financial year, one of the projects that was randomly selected for an Effectiveness Review was the 'Building Resilience in the Arid and Semi-Arid Lands of Northern Kenya' project (henceforth, the 'Building Resilience project'). The project was part of a wider programme that has been implemented by the 'La Nina Consortium' since 2011. The consortium, which - at the time of this evaluation - included Oxfam and four other agencies, worked across several counties in northern Kenya. However, the Building Resilience project specifically comprises Oxfam's activities in Turkana County in the third and fourth phase of the consortium's activities, which ran from July 2012 to April 2015.

The project was designed to build the resilience of project participants to a number of different shocks and stresses. Although households in Turkana have increasingly begun to settle in fixed locations, livestock herding continues to be important for people's livelihoods, and households' livelihoods remain susceptible to droughts - which threaten the area annually - as well as floods and outbreaks of human and animal diseases. Anthropocentric risks, such as fire, livestock theft, and conflict are also common.

The project worked at several different levels to try and reduce households' vulnerability to these risks. Within communities, the project adopted a Community-Managed Disaster Risk Reduction (CMDRR) approach to ensure the programme of support was well-suited to each community's needs. The project worked with local communities to set up Community Disaster Management Committees (CDMCs), which were then assisted with training and in writing contingency plans to better deal with crises. The project also sought to integrate communitylevel plans and committees into the work of the county government. Finally, the project tried to improve the flow of information across the county, both in terms of livestock health and earlywarning systems.

\section{EVALUATION APPROACH}

The Effectiveness Review, for which the fieldwork was carried out in June and July 2016, aimed to evaluate the success of this project in enabling households to maintain and improve their well-being, despite shocks, stresses and uncertainty. The survey work covered 19 sub-locations across the three sub-counties where the project was operating. Sub-locations are specific geographical areas, similar to municipalities, which, in general, correspond to villages.

This Effectiveness Review used a quasi-experimental evaluation design to assess the impact of the project activities. This involved comparing those households that participated in the project to a group of comparison households that were similar to the project participants. This means that this Effectiveness Review can only identify the household- and community-level effects of the project. Activities operating at the district or national level, including the project's advocacy work, are not included in this evaluation.

In the project communities, 280 project households from seven project communities - were sampled using a systematic random sampling procedure. For the comparison, 12 non-project communities were identified, which were comparable to the project communities in terms of a 
number of key characteristics, including the dominant livelihood strategies employed by community members, wealth, and distance from Lake Turkana and major rivers. Within these comparison communities, 540 households were sampled using the same sampling technique as in the project communities.

At the analysis stage, the statistical tools of propensity-score matching and multivariate regression were used to control for apparent baseline differences between the households in the project and comparison communities, to increase confidence when making estimates of the project's impact.

The primary aim of the Effectiveness Review was to investigate the project's impact on building resilience to shocks and stresses. This was assessed by identifying 26 characteristics that are thought to be associated with resilience for which data could be collected in the household survey. These characteristics were formulated under Oxfam GB's multidimensional framework for measuring resilience, and developed through discussions with project staff and focus groups conducted in local communities. In general, these indicators were chosen to focus on the intermediate steps between project activities and final well-being outcomes. A full list of indicators and a summary of the results for each is shown in Table 1.

Table 1: Characteristics of resilience examined in this Effectiveness Review

\begin{tabular}{|c|c|c|c|}
\hline Capacity & Characteristic & $\begin{array}{l}\text { Connected to } \\
\text { project logic? }\end{array}$ & $\begin{array}{l}\text { Evidence of } \\
\text { positive } \\
\text { impact? }\end{array}$ \\
\hline \multirow{10}{*}{ Absorptive } & Livelihood diversity & Yes & Yes \\
\hline & Livestock diversity & No & No \\
\hline & Herd size & No & Yes \\
\hline & Access to drinking water & No & No \\
\hline & Access to water for livestock & No & No \\
\hline & $\begin{array}{l}\text { Awareness of the community } \\
\text { contingency plan }\end{array}$ & Yes & Yes \\
\hline & Savings & Yes & No \\
\hline & Access to early-warning information & Yes & No \\
\hline & Access to back-up food supplies & No & Yes \\
\hline & Dietary diversity & Yes & No \\
\hline \multirow{7}{*}{ Adaptive } & Remittances or formal earnings & No & No \\
\hline & Access to credit & Yes & Yes \\
\hline & Education of household members & Yes & No \\
\hline & Growth of fruits/vegetables & Yes & Yes \\
\hline & Access to markets & No & No \\
\hline & Experience of disputes over resources & No & No \\
\hline & Ownership of productive assets & Yes & Yes \\
\hline \multirow{9}{*}{ Transformative } & Attitude to change & No & No \\
\hline & Adoption of innovative practices & Yes & Yes \\
\hline & $\begin{array}{l}\text { Involvement in community-level disaster } \\
\text { management }\end{array}$ & Yes & Yes \\
\hline & Capacity of CDMCs & Yes & Yes \\
\hline & Participation in community groups & Yes & No \\
\hline & Voice of women in the community & Yes & No \\
\hline & $\begin{array}{l}\text { County/national integration of community } \\
\text { plans }\end{array}$ & Yes & No \\
\hline & $\begin{array}{l}\text { Ability to make complaints/hold } \\
\text { government to account }\end{array}$ & Yes & No \\
\hline & Voice of disabled in the community & Yes & Yes \\
\hline
\end{tabular}


Our data suggest that the project improved the resilience of project households. Project households scored positively on average in 44 percent of the resilience indicators identified for this Effectiveness Review, compared with 38 percent for the comparison group. The largest impacts of the project were in the 'absorptive' and 'transformative' capacities, highlighting particularly in the latter capacity - the project's efforts to establish the CDMCs and encourage household adoption of new drought/risk mitigation practices. In the 'absorptive' capacity, the positive impact was driven largely by evidence of greater livelihood diversity among project households, as well as greater awareness of community disaster-management plans. In the 'adaptive' capacity, there was evidence of greater access to credit among project households, as well as evidence of greater crop cultivation. However, we could not find evidence for any improvement in access to livestock markets or changes in educational attainment among household members.

There were a number of other aspects of the project logic at earlier stages of the causal chain that it was possible to investigate in this Effectiveness Review. For example, the results clearly show that the project households in our survey participated more in the trainings and groups implemented by the project than comparison households. We can be especially confident that the project increased participation in Community Disaster Management Committees (CDMCs) because we controlled for baseline group participation using recalled data in our analysis. Households in the project communities were much more likely to have received training, particularly in drought preparedness, livestock health and management of pasture lands, but also in issues relating to gender, advocacy and how to better claim goods and services from government and other providers. However, when we assess the implementation of particular activities that were believed to be connected to the project proposals put forward by the CDMCs, there was no evidence - with the exception of the provision of back-up food - of greater implementation in project communities. This could be due to government or other NGO initiatives in the study communities.

Our data suggest that the project had some positive effect on the probability of livestock ownership, but no strong evidence that the number of animals owned by project households has increased, or any decrease in the number of animals lost to disease, theft, drought or flood. Barriers to market are clearly still an issue, with three-quarters of those project households trying to sell in the previous 12 months reporting that distance to market was a serious constraint - a proportion not significantly different from households in comparison communities.

There is some evidence that the project affected households' decisions on whether to engage in farming. Project households were also more likely to sell their agricultural produce. There were also positive and significant effects with regards to the amount of land that households farmed and the number of crops in their portfolio, but there was no clear effect on increased involvement of women in crop cultivation.

There is evidence that the project has also effected an increase in households engaging in nonfarm income-generating activities. This is particularly driven by an increase in the proportion of households having their own household business, such as a retail outlet, café or accommodation. Interestingly, there is evidence that project households are significantly less likely to be engaged in the harvesting of plants or wood to make charcoal. This is likely due to the project's aim to encourage proper utilization of natural resources.

Some of the largest differences identified between project and comparison households related to the greater take-up of risk-management strategies by households in the project communities. We should, however, be somewhat cautious about interpreting the results in a completely positive light. In particular, it may be that these measures were necessary due to project households' continued exposure to risk. This is especially concerning if these sorts of investments come at the expense of investing in income-generating activities. 
We included a measure of wealth in our analysis to test whether there were any differences in terms of final outcomes between project and comparison households in our sample - that is, whether project households had been able to improve their well-being in despite shocks, stresses and uncertainty. There were, however, no clear effects of the project in terms of household wealth. In part, this may be because the survey work was carried out when households in the project areas faced only limited drought and some localized flooding. It is difficult to examine households' resilience using final well-being indicators when they are not currently affected, or have not recently been affected, by shocks and stresses. Also, it may take a long time for projects of this type to influence outcomes such as wealth.

The main results of this Effectiveness Review are summarized in Table 2. Given the number of indicators that were directly connected to project outputs included in the overall measures of resilience (and its capacities) it is recommended to look carefully at each constituent indicator when interpreting the results.

Table 2: Key results of this Effectiveness Review

\begin{tabular}{|c|c|c|c|c|}
\hline \multicolumn{2}{|l|}{$\begin{array}{l}\text { Outcome } \\
\text { area }\end{array}$} & \multirow{2}{*}{$\begin{array}{l}\text { Connected to } \\
\text { project } \\
\text { logic? }\end{array}$} & \multirow{2}{*}{$\begin{array}{l}\text { Evidence of } \\
\text { positive } \\
\text { impact? } \\
\text { Yes }\end{array}$} & \multirow{2}{*}{$\begin{array}{l}\text { Comments } \\
\text { The main evidence of impact was seen in } \\
\text { livelihood diversity and awareness of } \\
\text { community disaster plan. There was little } \\
\text { evidence of any impact on dietary } \\
\text { diversity or households receiving helpful } \\
\text { early-warning information. }\end{array}$} \\
\hline \multirow{3}{*}{ Resilience } & Absorptive capacity & & & \\
\hline & Adaptive capacity & \multirow[t]{2}{*}{ See Table 1} & Yes & $\begin{array}{l}\text { Project households had better access to } \\
\text { credit, but their access to markets had } \\
\text { not been improved. There was evidence } \\
\text { that project households were more likely } \\
\text { to cultivate crops. }\end{array}$ \\
\hline & Transformative capacity & & Yes & $\begin{array}{l}\text { The strongest impacts were around } \\
\text { adoption of innovative practices and the } \\
\text { capacity of the CDMC. No evidence of } \\
\text { impact on the voice of women in the } \\
\text { community or evidence of integration of } \\
\text { CDMC plans into higher administrative- } \\
\text { level plans. }\end{array}$ \\
\hline
\end{tabular}

No evidence of impact was found for

\begin{tabular}{|c|c|c|c|}
\hline Wealth & Yes & No & $\begin{array}{l}\text { No evidence of Impact was found for } \\
\text { either current wealth or change in wealth } \\
\text { levels during the course of the project. }\end{array}$ \\
\hline
\end{tabular}

Small increase in overall probability of household owning livestock, but no differences in livestock sales or losses. Barriers to market still very clearly an issue.

$\begin{array}{lll}\text { Livestock } & \text { Yes }\end{array}$

Project households were more likely to cultivate crops, and in turn a greater proportion of households sold crops. There were no clear effects on increased women's responsibility for crops

There was an increase among project households in their involvement in

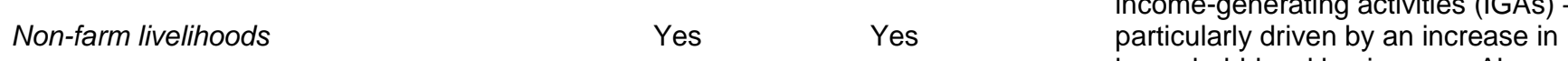
household-level businesses. Also some evidence of an increase of women's involvement in IGAs.

Project households were more likely to implement a variety of risk-management and drought responses. Despite this, there is still significant scope for greater adoption among households. 


\section{PROGRAMME LEARNING CONSIDERATIONS}

\section{Take a more holistic approach to evaluation design at the start of future projects, including discussions around suitable indicators and the possible establishment of a comparison group.}

The quasi-experimental methodology deployed in this Effectiveness Review was successful due to the extensive inputs of project and partner staff during the fieldwork. The discussions around suitable comparison communities and the selection of good indicators of resilience were particularly rigorous and inclusive. However, it would have been better to have had these discussions before the project activities began. As a minimum, this would have helped create a more comprehensive Monitoring, Evaluation and Learning plan with a wide range of resilience indicators. Going further, it would also have been possible to implement a more robust evaluation design if the comparison group had been established before the project started and baseline data had been collected in project and non-project communities. To support this process in the future, the impact evaluation team should provide tools and resources to help project and programme staff with quasi-experimental evaluation designs, especially on the subject of setting up a comparison group. In addition, advice should be provided on opportunities to take advantage of planned programme design, e.g. use of phased implementation approach, in order to better utilize quasi-experimental evaluation methods. This learning point therefore applies not only for programme staff but also those working on monitoring and evaluation.

\section{Continue to work on efforts to improve access to livestock markets in and around the project communities.}

The results from the Effectiveness Review indicate that there is a need to assess how best to strengthen the work on livestock, in what remains a dominantly pastoralist economy. While there was some evidence to suggest an increased probability of project households owning livestock, there was no evidence of reduced livestock loss or greater herd sizes generally. Of those households who reported trying to sell their livestock in the previous 12 months, more than three-quarters cited distance to market as a serious barrier to making sales. It is clearly a cross-cutting issue, but the results here warrant further analysis of options to improve pastoralists' access to markets, as well as strengthen the well-being of their livestock.

\section{Encourage further household implementation of risk- management strategies.}

One of the clear successes of the initiative has been in the greater take-up of risk-management strategies by households in the project communities. While the difference in take-up between project and comparison households is striking, there is clearly room to encourage greater adoption of these strategies. It is also worth mentioning the small but significant difference achieved in the proportion of project households cultivating and then selling crops. While further on-the-ground sensitization may be out of the scope of the next stage of development, there may be an option for Oxfam to be a convener and influencer in advocating for district-level takeup by government agricultural extension workers. 
Being an intermediate step in the project's theory of change, it would also be interesting to carry out a subsequent review to assess whether this further implementation of various coping strategies does indeed generate greater impact for 'higher-level' outcomes, such as food security, wealth status and resilience.

\section{Review the success or otherwise of the CDMC proposals, especially whether CDMC plans have been integrated into county-wide development plans.}

One of the major successes of the project has been in the implementation and support of the community disaster-management committees. There was evidence that communities supported by the project had greater engagement in community-level disaster planning and were more aware of the contents of any disaster-management plan. They also had greater confidence in the capacity of the CDMC to help the community in difficult times. But there are two areas that warrant further research - both of which were key aspects of the project but did not feature in the focus of this Effectiveness Review. Firstly, it would be interesting to review a selection of the CDMC proposals for community-based initiatives - both in terms of the quality of the proposal and the success or otherwise of the subsequent intervention. Due to the nature of this review, such fine-grained and small-scale analysis was not possible but we would recommend follow-up research on one of the key aspects of the project. In addition, it was made explicit from the outset that one of the objectives was that the local-level CDMC plans would be integrated into county-level disaster-management plans. Again, detailed analysis was outside the scope of this review, but there appears to be an opportunity to build on the apparent success of the local CDMCs to gain learning and to leverage change at a higher administrative level, thereby potentially effecting greater change. 
Oxfam GB's Global Performance Framework is part of the organization's effort to better understand and communicate its effectiveness, as well as enhance learning across the organization. Under this Framework, a small number of completed or mature projects are selected at random each year for an evaluation of their impact, known as an 'Effectiveness Review'. One key focus is on the extent to which they have promoted change in relation to relevant Oxfam GB global outcome indicators.

During the 2016/17 financial year, one of the projects that was randomly selected for an Effectiveness Review was the 'Building Resilience in the Arid and Semi-Arid Lands of Northern Kenya' project (henceforth the 'Building Resilience project'). The project was part of a wider programme that has been implemented by the 'La Nina Consortium' since 2011. The consortium, which - at the time of this evaluation - included Oxfam, Agence d'Aide à la coopération technique et au développement (ACTED), Concern Worldwide, and Vétérinaires Sans Frontières (VSF)-Germany and received funding from the European Commission Humanitarian Aid and Civil Protection Office (ECHO), worked across several counties in northern Kenya (Turkana, Mandera, Wajir, Marsabit, Samburu and West Pokot). However, the Building Resilience project specifically comprises Oxfam's activities in Turkana County in the third and fourth phase of the consortium's activities, which ran from July 2012 to April 2015. The specific sub-location and sub-counties in which the Building Resilience project operated are shown in Figure 1.1.

The project was designed to build the resilience of project participants to a number of different shocks and stresses. Although households in Turkana have increasingly begun to settle in fixed locations, herding of livestock continues to be important for people's livelihoods. This may be supplemented by growing crops, harvesting and selling wild plants - such as prosopis and aloe vera, mining, and running small household businesses. However, households' livelihoods remain susceptible to droughts - which threaten the area annually - as well as floods and outbreaks of human and animal diseases. Anthropocentric risks, such as fire, livestock theft, and conflict are also common.

The project worked at a number of different levels to try and reduce households' vulnerability to these risks. Within communities, the project adopted a Community-Managed Disaster Risk Reduction (CMDRR) approach to ensure the programme of support was well-suited to each community's needs. The project worked with local communities to set up Community Disaster Management Committees (CDMCs), which were then assisted in writing long-term development plans as well as contingency plans to better deal with crises. To realize these plans, CDMCs could then initially apply to Oxfam (and then the consortium as a whole) for grants to facilitate certain community-specific activities (such as supporting savings and credit groups, aloe vera harvesting, or gypsum mining). The project also provided training on topics such as advocacy, running businesses, and disaster risk management to the CDMCs, encouraging CDMC members to pass on their knowledge and understanding to others in the community. The project also undertook some activities at the county-level. Firstly, the project sought to integrate community-level plans and committees into the work of the county government. Additionally, the project tried to improve the flow of information across the county, both in terms of livestock health and early-warning systems. The project also continued some humanitarian activities from its previous phases, providing an 'emergency envelope' scheme, which allowed funds for emergencies to be dispensed rapidly.

The Effectiveness Review, for which the fieldwork was carried out in June and July 2016, aimed to evaluate the success of this project in enabling households to maintain and improve their well-being, despite shocks, stresses, and uncertainty. The survey work covered 19 sublocations across the three sub-counties where the project was operating. Sub-locations are specific geographical areas similar to municipalities, which, in general, correspond to villages. 
Figure 1.1: Project Areas for Kenya Effectiveness Review

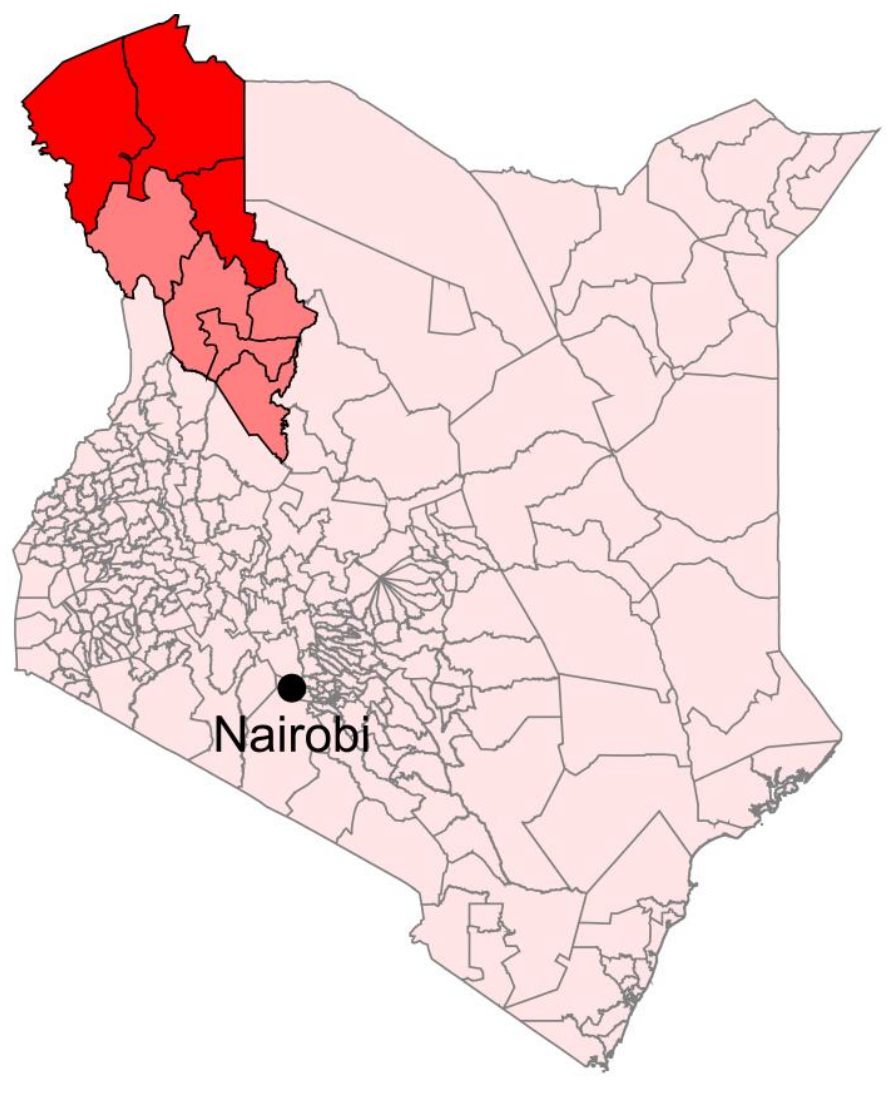

\section{Turkana County - Project Sub-Counties \\ Turkana County - Non-Project Sub-Counties Non-Project Counties}

Source: Oxfam

This report presents the findings of the Effectiveness Review. Section 2 briefly reviews the activities and the logic of the project. Section 3 describes the evaluation design used, and Section 4 describes how this design was implemented. Section 5 presents the approach used to measure resilience. Section 6 shows the results of the data analysis based on the comparison of outcome measures between project and non-project households. Section 7 concludes with a summary of the findings and some considerations for future learning. 


\section{PROJECT DESCRIPTION}

\subsection{PROJECT ACTIVITIES}

The project under review used a Community-Managed Disaster Risk Reduction (CMDRR) approach to try and build resilience within its target communities, whilst also supporting countylevel initiatives to better manage potential risks and disasters.

The project operated in three sub-counties within Turkana County in northern Kenya - Turkana Central, Turkana West and Turkana North. Turkana is an area of arid and semi-arid land (ASAL) covering over 70,000 square kilometres, but with a sparsely distributed population of approximately one million people. Although households have increasingly begun to settle in fixed locations across Turkana, herding of livestock continues to be an important part of people's livelihoods, with roughly 60 percent of the population depending on pastoralism. A further 20 percent of households are agro-pastoralist, growing crops such as sorghum, maize, and cowpeas, to supplement their livelihoods. Households may also derive income from harvesting and selling wild plants - sometimes burning the wood to make charcoal first - as well as from the extraction of other natural resources, including gold mining, fishing and, more recently, oil drilling. Additionally, certain households may operate small-scale businesses, such as making and selling handicrafts or simple grocery stores, to generate extra income.

The majority of households, therefore, rely on pastoralism and agriculture; however, their livelihoods are increasingly under threat from a range of natural and anthropogenic hazards. Drought remains a major threat to Turkana. The 2011 East Africa Drought had a significant effect on communities in the region, with widespread food insecurity alongside a substantial deterioration in health and sanitation. The 2011 drought also resulted in mass migration as pastoralists struggled to find sources of water and pasture for their livestock. This, in turn, led to conflict over vital natural resources. Although the 2011 drought was far more severe than in other years, Turkana annually endures droughts of between one and two months, where many communities rely on direct food aid. These droughts are sometimes accompanied by fires, especially in areas with higher population density. However, although, the weather is typically very dry in Turkana, flash flooding can also occur during the wetter months (usually March to May) especially around the major rivers that run through the county - the Turkwel River (and its main tributary, the River Kawalasee), the Kerio River, and the Tarach River. These floods can result in crops and assets being swept away, communities being cut off (as roads become impassable), and the spread of both human and livestock diseases. In addition, the coping strategy of charcoal burning has contributed significantly to deforestation in the region, further exacerbating the effects of flooding.

Many of the shocks and stresses faced by communities in Turkana are directly linked to human activities. As mentioned above, mass migration - often in response to shortages in natural resources - can result in conflict. Within Turkana, people mainly migrate from the north of the county towards the lake area, where it is easier to access water and fishing-oriented livelihoods. In general, this kind of intra-Turkana migration is thought to have a limited impact on conflict, because Turkanas from the north will often have relatives with whom they can reside when they move towards the lake area. However, migration from neighbouring Uganda, South Sudan and Ethiopia is not so benign. Around Lake Turkana, some beach management units (BMUs) - the co-operatives responsible for coordinating fishing activities on the lake - have reported that, in areas with particularly high fish stocks, carrying firearms to ensure security is commonplace. Additionally, cattle rustling and theft of other livestock is widespread in the area, creating tensions between Turkanas and those from outside the county. 
The Building Resilience project aimed to build households' resilience to the shocks and stresses described above, working directly with local communities, as well as with county-level authorities.

The Building Resilience project was part of a much wider programme, which had been implemented by the 'La Nina Consortium' since 2011 across six ASAL counties in Kenya (Turkana, Mandera, Wajir, Marsabit, Samburu and West Pokot). The first and second phases of this programme consisted of a wide-reaching humanitarian response to the 2011 East Africa Drought, running throughout 2011 and 2012. The Building Resilience project comprised Oxfam's contribution to the third and fourth phases of the La Nina Consortium's activities in Turkana, which heralded a transition from pure emergency response to a broader resiliencebuilding programme. The third and fourth phases began in April 2013 and finished in July 2015. During this period, the consortium was composed of Oxfam, Agence d'Aide à la coopération technique et au développement (ACTED), Concern Worldwide, and Vétérinaires Sans Frontières (VSF)-Germany and received funding from the European Commission Humanitarian Aid and Civil Protection Office (ECHO). ${ }^{1}$ The consortium has continued to implement resilienceoriented activities in the same locations past the end of the Building Resilience project, undertaking a fifth phase which ran until March 2016. At the time of the fieldwork, plans for a sixth phase were being formulated to run from 01 May 2016 to 31 April 2017.

The Building Resilience project set four final outcomes on which it hoped to achieve change:

1. To contribute to people being able to claim their rights to access basic services.

2. To improve resilience through increased income and food security of women during 'normal times' and during crises.

3. To contribute to the protection of human lives and livelihoods through peace building and conflict prevention.

4. To enhance resilience through proper utilization of natural resources and other extractives, benefiting both present and future generations.

As such, the project sought to build resilience both by supporting sustainable livelihoods and through disaster risk reduction. Vitally, the project aimed to achieve change at the household, community and county level, so its activities operated at several different scales.

The Building Resilience project implemented many of its primary activities through the Community-Managed Disaster Risk Reduction (CMDRR) approach, ensuring that the project's work was well-suited to each community's needs. The foundations of this approach involved setting up Community Disaster Management Committees (CDMCs) who could represent community members and then determine the exact nature of support that Oxfam would provide to a particular community. Whilst community committees of this type are not uncommon in Turkana, the way that the CDMCs were formed and subsequently managed was amongst the most distinctive aspects of the Building Resilience project. To form a CDMC, a large group of approximately 60 people participated in a community meeting at each site. The participants in the community meeting were then guided through Participatory Disaster Risk Assessment (PDRA), including a workshop to help them identify and rank the main risks facing the community. They were also asked to nominate between 10 and 15 people to form the CDMC for the community. The fact that CDMC members were selected by a much wider pool of community members was designed to ensure the CDMC would be sufficiently representative of the community's needs and villages in that location/sub-location. As an extra check, the CDMC membership was restricted to ensure that women, the elderly, the youth and the disabled were all represented.

Once the CDMCs were formed in this way, the Building Resilience project provided them with several types of support. Firstly, CDMC members participated in a series of workshops and training events focused on writing long-term development plans and contingency plans, both specific to the community. As part of these long-term development plans, CDMCs were 
encouraged to come up with potential small-scale projects that could benefit their community at large. Once these ideas were fixed, the CDMCs were provided training on proposal writing and opening an official bank account, so that they could formally apply to the La Nina Consortium for grants of up to 6000 EUR to support these small-scale projects. Some example projects included the managing harvesting and sale of prosopis and aloe vera, setting up savings and credit groups, and the mining and sale of gypsum. The funds could only be released if formal meeting minutes were submitted to Oxfam, in order to foster transparency and careful deliberation when making plans for the community. The Building Resilience project also worked to build formal linkages between the CDMCs and private sector actors, as well as the county government, to further support the community-specific proposals. In particular, the long-term development plans that were developed by the CDMCs were integrated into county-level development plans.

A number of other trainings were provided to CDMC members in the hope that the knowledge and understanding would be passed on to the community at large. For example, CDMC members were also trained in good business practices, not only to support their efforts to apply for and manage grants, but also to support non-farm household businesses across the community. Additionally, CDMC members participated in training on their rights, governance, accountability and advocacy, to enable them to better make claims to the county government and other local stakeholders. Indeed, the project set up a specific committee in each community - separate from the CDMCs - through which complaints could be channelled both to the consortium and other stakeholders, such as the county government. To bolster these efforts to improve accountability, community members were given a special mobile phone number that they could call anonymously to provide feedback on the consortium's work and other issues.

A number of the Building Resilience project's other activities sought to impact not only the communities in which the CMDRR approach was adopted, but also the whole of Turkana County. Many of these activities were focused on sharing information. For example, the project collected data on the status of a number of water points and assisted with monitoring the threat of animal diseases across the county to support early-warning systems. As well as collecting information, the consortium aimed to coordinate local stakeholders by holding meetings with the county government and other NGOs to ensure data were shared.

The Building Resilience project also contributed to developing some of the humanitarian work that had been undertaken in the first two phases of the La Nina Consortium's work. One particular component of this work involved creating an 'emergency envelope' mechanism, which allowed funds for humanitarian interventions to be deployed quickly. Under this mechanism, any consortium members were able to submit short proposals to the consortium lead, following a number of interim triggers, including lack or rains (or heavy rain), food prices, or the spread of animal disease. The decision-making process for these proposals was especially rapid. Once proposals were received, and analysed by the consortium secretariat and technical lead, they were immediately sent to each partner NGO, giving just 24 hours for feedback. ${ }^{2}$ As the coordinating partner, Oxfam would then make the final decision on whether or not the proposed humanitarian work could go ahead. Therefore, the 'emergency envelope' can be dispatched within a few days of the proposal being written.

Thus, the Building Resilience project comprises a mix of several different strands, both at the community and the county level, and combining support for sustainable livelihoods with more direct disaster risk reduction. 


\subsection{PROJECT LOGIC AND INTENDED OUTCOMES}

In this section, we describe how the project was supposed to achieve its goals. Using existing documentation about the project as well as through discussions with the team implementing the project, we can map out the intended causal links from project activities (green), via outputs (orange) and intermediate outcomes (red), to overall resilience outcomes (purple). This results in the logic model shown in Figure 2.1. It should be noted that this diagram stops at the factors that could be considered drivers or characteristics of resilience, and does not include the final outcomes beyond resilience (such as improved well-being and realisation of rights), that the project may have been trying to promote in the long run.

Figure 2.1: Logic Model for the Building Resilience project

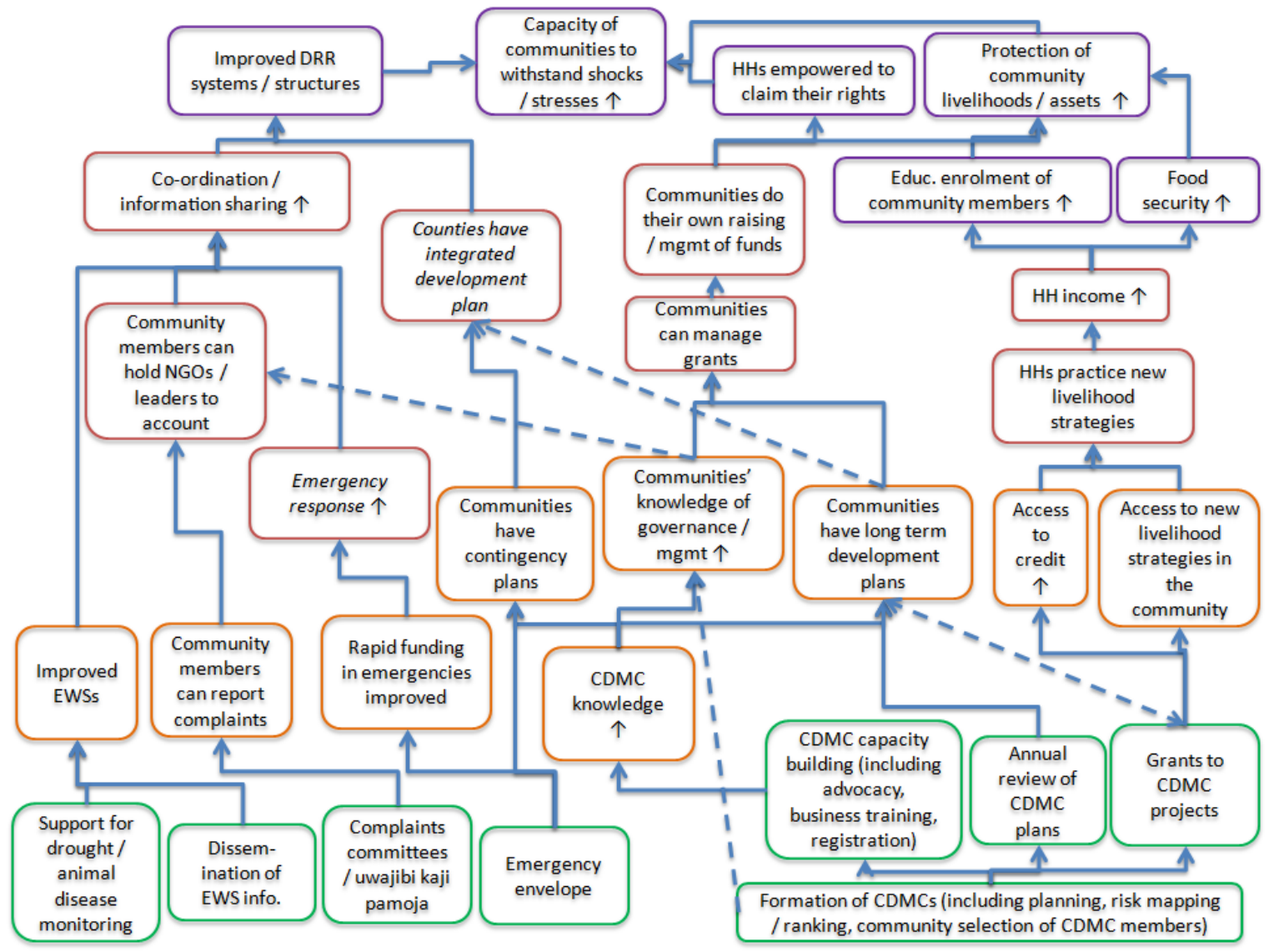

\section{Key}

Project Activities

Outputs

Intermediate Outcomes

Resilience Outcomes

The formation of and support to the CDMCs aimed to build resilience through a number of different channels. The provision of grants to the CDMC-led projects was intended to enable community members to pursue income-generating activities and strategies outside of pastoralism and agro-pastoralism, in order to diversify their livelihoods. In the communities where savings and credit groups were established, the grants were designed to relax constraints on borrowing so that household could invest in new non-farm household businesses. Alternatively, in communities that used the grants to invest in the harvest/mining and sale of natural resources - including prosopis, aloe vera and gypsum - it was thought that 
households would be more aware of natural resource-oriented livelihoods and better connected to local markets (such as the local refugee camps at Kakuma that demand firewood). This was supposed to make these types of livelihood strategies viable and useful alternatives to pastoralism and agro-pastoralism.

By facilitating alternative livelihood strategies, the Building Resilience project also sought to improve households' food security and allow them to invest more in household members' education. Food security is important not only in and of itself, but also because it provides individuals with the energy and health levels required to generate income. Education was also seen as a vital component of resilience, insofar as it could enable households to send certain members to work in other locations - including nearby urban areas - to earn and send back remittance payments.

The CMDRR approach was also intended to empower households to better claim their rights, especially during shocks and stresses. In part, it was hoped this would be a direct consequence of the procedure for obtaining the grants - the CDMCs needed to write long-term development plans and contingency plans, set up formal bank accounts, and submit grant proposals in order to access the consortium grants which they managed with technical support from the consortium partners. However, an additional objective was that communities would be better able to make demands or apply for other types of grants from stakeholders outside the consortium including the county governments in the future. The trainings provided to CDMC members - on governance, advocacy, accountability, running businesses, and so on - were designed to be passed on to other households in the community, to make sure the community at large was able to make claims to the county government and other stakeholders. The complaints committees were set up to further build the culture of accountability, ensuring that even the CDMCs were answerable to the community at large.

The CDMC activities also aimed to contribute to the project's county-level disaster risk reduction efforts. By integrating communities' long-term development plans and contingency plans into county-level plans and by channels through which individuals could make complaints, it was hoped the county government's disaster risk reduction strategies would better reflect communities' needs. The project also sought to supply the county government with the timely and accurate information required to respond to risks effectively. It was assumed that, by providing information on triggers such as water access and animal disease outbreaks, the county government and other local stakeholders would respond better to crises. Indeed, the monitoring activities necessitated by the 'emergency envelope' mechanism were also thought to improve the quality and quantity of relevant information to which key actors had access. This represents an additional benefit of the 'emergency envelope' system, over and above improving the consortium's ability to unlock funds quickly and appropriately during emergencies. 
The central problem in evaluating the impact of any project or programme is how to compare the outcomes that resulted from that project with what would have been the case had the project or programme not been carried out. In the case of this Effectiveness Review, information about the situation of households in the project communities was collected through a household questionnaire, but clearly it was not possible to know what their situation would have been had the project activities not been undertaken. In any evaluation, this 'counterfactual' situation cannot be directly observed: it can only be estimated.

In the evaluation of programmes that involve a large number of units (such as individuals, households, or communities), it is possible to make a comparison between units that were subject to the programme and those that were not. As long as the two groups are similar in all respects except for the implementation of the specific project, observing the situation of those where the project was not implemented can provide a good estimate of the counterfactual.

This evaluation focuses on assessing both the household- and community-level impacts of the project. Therefore, we aim to compare the direct beneficiaries within project communities, with similar households in similar non-project communities. For the purposes of this evaluation, we use the term 'community' to refer to the sub-location, which typically corresponds to a village in the Turkana context.

An ideal approach to an evaluation such as this is to select the sites in which the project will be implemented, as well as the households who can participate in the project, at random. Random selection minimizes the probability of there being systematic differences between the project participants and non-participants, and so maximizes the confidence that any differences in outcomes are due to the effects of the project.

However, in the case of the project examined in this Effectiveness Review, the communities where the project was implemented were not selected at random.

Instead, the implementers targeted so-called 'cliff-hanger' communities. This meant that the project sought to work in the communities that were not the very poorest - as such communities would already be involved in World Food Programme (WFP) food distribution projects - but neither were the communities rich within the context of Turkana. Given the prevalence of pastoralism and agro-pastoralism in this context, wealth was principally assessed through livestock holdings.

The Building Resilience project was also implemented exclusively in communities that had been involved in the first and second phases of the La Nina Consortium's work. Therefore, at the start of the project under evaluation the project communities had already received a substantial programme of support from Oxfam and other consortium members.

However, within Turkana - and even within the same sub-counties - there were a number of other communities with similar characteristics that faced similar risks, but that were not included in the Building Resilience project. In particular, it was possible to identify communities that were comparable in terms of wealth and prevailing livelihoods strategies and that had been involved in the first two phases of the La Nina Consortium's work, but had not been reached by the Building Resilience project (or indeed any of the La Nina Consortium's work after 2012). This allowed a 'quasi-experimental' evaluation approach to be adopted in which the situations of households in communities not included in the project - in so-called 'comparison' sites - were assumed to provide a reasonable estimate for the counterfactual of households who participated in the project. 
The Building Resilience project sought to have community-wide effects. Many development projects focus solely on a selected sub-sample of households in the target communities, but this was not the case for the project being evaluated. Although much of the project's work was channelled through the CDMCs, it was hoped that these activities would reach all households in the community. Therefore, in this evaluation, it is possible to sample from the population as a whole in both the intervention communities and the comparison communities.

The statistical analysis used in this evaluation allowed us to improve the confidence in our comparison between those households in communities that did and did not participate in the project. Households in the project communities were 'matched' with households with similar characteristics in the comparison communities. Matching was performed based on a variety of observable characteristics - including household size, education levels, productive activities, and indicators of material well-being, such as housing conditions and ownership of assets. Since some of these characteristics may have been affected by the project itself (particularly those relating to productive activities and wealth indicators), matching was performed on the basis of these indicators before the implementation of the project. Although baseline data were not available, survey respondents were asked to recall some basic information about their household's situation in 2012, before the project was implemented. This recalled baseline data is unlikely to be highly accurate. However, it still serves as a suitable proxy for households' baseline situation, enhancing the reliability of the comparisons made in this report.

The survey data provided many baseline household characteristics on which matching could be carried out. (The characteristics that were in fact used are listed in Appendix 3.) In practice, it is very difficult to find households in the comparison communities that correspond exactly in all these characteristics to households in the project communities. Instead, these characteristics were used to calculate a 'propensity score' - the conditional probability of the household participating in the project, given particular background variables or observable characteristics. Households in the project and comparison communities were then matched based on this propensity score. After matching, it was possible to test whether the distributions of each baseline characteristic were similar between the two groups. Technical details of this approach are described in Appendix 3.

As a check on the results derived from the propensity-score matching process, results were also estimated using multivariate regression models. Like propensity-score matching, multivariate regression also controls for measured differences between the intervention and comparison groups, but it does so by isolating the variation in the outcome variable explained by being in the intervention group after the effects of other explanatory variables have been accounted for. The regression models tested are described in Appendix 4.

It should be noted that both propensity-score matching and multivariate regression rely on the assumption that the 'observed' characteristics (those that are collected in the survey and controlled for in the analysis) capture all of the relevant differences between the two groups. If there are 'unobserved' differences between the groups - such as individuals' attitudes or motivation, differences in local leadership, weather, or other contextual conditions - then estimates of outcomes derived from them may be misleading. This is a cause for particular caution when evaluating a project in which participants were, to some extent, self-selected. This point is further discussed in Sections 5 and 6, when interpreting the statistical results. 


\section{DATA}

\subsection{RESPONDENTS INTERVIEWED}

To form a sample of project and comparison households for this evaluation, we began by selecting the project communities on which to focus the evaluation.

Two out of the 12 project sites - Kataboi and Kapua - were excluded from the sample because the first and second phases of the La Nina Consortium's programme were not actually implemented there. As a consequence, the external support that these communities had received between 2011 and 2012 was different from the other locations in which the Building Resilience project was working. Although it would have been possible to find comparison sites for Kataboi and Kapua in communities where the La Nina Consortium had never worked, this would have resulted in too much heterogeneity in the overall sample. Notably, if both the intervention group and the comparison group were composed of some households that were involved in the first and second phases of La Nina Consortium's work and some that were not, the data analysis would effectively involve making two sets of comparisons using smaller subsamples. However, these sub-samples would be too small to make these comparisons meaningful.

A further three out of the 12 project sites - Kokuro, Lokamarinyang and Loruth Esekon - were unreachable during the time of the survey owing to security concerns. These communities are situated in the extreme north of Turkana County, in and around the disputed area of land known as the 'llemi Triangle' on the Ethiopian and South Sudanese borders. Although accessing these communities would have been possible using security escorts and exploiting Oxfam's relationships with community leaders, gaining access to similar communities where the La Nina Consortium had not been working would have been untenable.

Even after dropping these five communities, the project sites that were sampled still stretch across the sub-counties of Turkana North and Turkana West. However, Kapua was the only project community located in Turkana Central.

To establish which communities would be suitable for comparison purposes, a list of key socioeconomic and geographical characteristics was drawn up, which was based on the original criteria used to determine whether communities could participate in the project. We also considered some criteria that may have tacitly influenced the selection of project sites. The characteristics used to select the comparison communities were:

- The dominant livelihood strategies employed by community members - especially in terms of the balance between pastoralism and other livelihoods

- Overall wealth levels in the community, especially in terms of livestock ownership

- Distance from the borders with South Sudan and Ethiopia

- Distance from Lake Turkana

- Distance from major rivers

- Presence of mining or other extractive activities in or near to the community

- Presence of schools and/or health clinics in the community.

Through discussions with the project staff, we could identify a total of 12 suitable comparison VDCs stretching across the Turkana North and Turkana West sub-counties. These were communities where neither the Building Resilience project nor any of the consortium members had worked after the second phase of the La Nina Consortium finished in 2012. 
During these discussions, we were also able to map out the other government and NGO initiatives that were operating in the same areas of Turkana. One of the largest projects operating in Turkana - the Hunger Safety Net Programme (HSNP) - provides regular unconditional cash transfers to very poorest households across all sub-locations in Turkana, in order to reduce extreme hunger and vulnerability. Similar county-wide distributions of food parcels were undertaken by WFP during the period of the Building Resilience project. However, since these activities were reasonably consistent across Turkana, especially for communities with similar average wealth levels, this did not directly affect our selection of the comparison sites.

There were several other NGOs operating outside the La Nina Consortium that implemented similar resilience-building projects in specific communities in Turkana, rather than across the county as a whole. Drawing on the knowledge of Oxfam staff, and by meeting key programme coordinators from Adeso, World Vision and Child Fund, it was possible to create a list of communities in which NGOs outside the consortium were working. These sites were explicitly excluded from our sample, so the project sites could be compared to communities in which there had been no similar activities during the project duration.

There were two other Oxfam projects that worked in a sub-sample of communities across Turkana, but were separate from the Building Resilience project. The 'Fish Value-Chain' sustainable livelihoods project worked with communities near to Lake Turkana to improve market linkages for fishermen and fisherwomen by offering business training, directly registering traders with the Chamber of Commerce, and providing inputs such as boats, fishing nets and storage facilities. Oxfam also implemented a WASH project, which worked to construct boreholes and solar water pumps, and then train people to maintain and rehabilitate existing water points. The locations in which these two projects worked overlapped substantially with the La Nina Consortium's activities. Therefore, for this evaluation, we aimed to ensure that, in both the intervention and comparison groups, there was a mix of communities that both had and had not been affected by Oxfam's Fish Value-Chain and WASH projects. This helps ensure that there were no systematic baseline differences, on average, between the intervention and comparison groups. The intervention and comparison sites in which these other Oxfam projects worked are shown in Table 4.1.

Table 4.1: Location of Oxfam Fish Value-Chain and WASH projects sampled communities

\begin{tabular}{|c|c|c|c|}
\hline $\begin{array}{l}\text { Intervention / } \\
\text { Comparison }\end{array}$ & Community & $\begin{array}{l}\text { Oxfam Fish Value-Chain } \\
\text { Project? }\end{array}$ & Oxfam WASH Project? \\
\hline \multirow{7}{*}{ 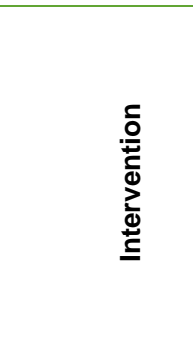 } & Kaalem & $\checkmark$ & \\
\hline & Kokiselei & $\checkmark$ & \\
\hline & Loritit & & $\checkmark$ \\
\hline & Lopusiki & & \\
\hline & Losajait & $\checkmark$ & $\checkmark$ \\
\hline & Kobwin & & \\
\hline & Karebur & $\checkmark$ & $\checkmark$ \\
\hline \multirow{12}{*}{ 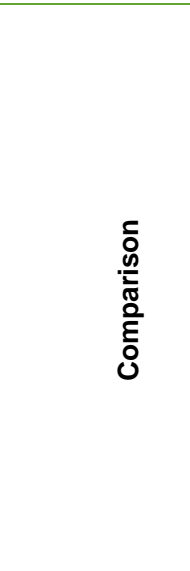 } & Kanagakipur & & \\
\hline & Riokomor & $\checkmark$ & $\checkmark$ \\
\hline & Nadunga & $\checkmark$ & \\
\hline & Milima Tatu & $\checkmark$ & $\checkmark$ \\
\hline & Kaeris & & \\
\hline & Namunyanak-Kirionok & & \\
\hline & Morungole & & \\
\hline & Nakalale & & \\
\hline & Kachoda & $\checkmark$ & $\checkmark$ \\
\hline & Lolupe & $\checkmark$ & \\
\hline & Nadwat & $\checkmark$ & \\
\hline & Lokangae & $\checkmark$ & $\checkmark$ \\
\hline
\end{tabular}

Resilience in Kenya: Impact evaluation of Building Resilience in the Arid and Semi-Arid Lands of Northern Kenya. Effectiveness review series 2016-17 
Since the Building Resilience project aimed to produce community-wide effects, it was necessary to generate a sample of households that adequately represented the communities as whole. To this end, we attempted to draw households at random from the entire population of each community.

Operationalising the random selection of households in the selected communities was somewhat difficult because accurate lists of households (e.g. from censuses or electoral registers) were not available. To resolve this problem, the survey team adopted a modified version of the 'left-hand rule', to generate a systematic random sample. This involved the following steps:

1. On arrival at the community, two landmarks - such as a market place, church or school were identified on opposite sides of the community.

2. An imaginary line was drawn between these two diametric landmarks to split the community into two 'halves'.

3. Through conversations with the village elders, the survey team estimated the number of households located in each 'half' of the community.

4. The required number of households for each 'half' of the community was calculated in proportion to the true number of households located there. ${ }^{3}$

5. The enumerators were distributed to each 'half' of the community, in proportion to the true number of households located there.

6. The interval for each 'half' of the community was calculated by dividing the total population for that 'half' of the village by the required number of households.

7. The first household to be interviewed was calculated using a simple random number generator. A circle of stones was place on the floor and numbered, and then a pen was spun in the centre of this circle to pick out a particular number. ${ }^{4}$

8. Using the two landmarks identified in Step 1 as starting points, the enumerator teams adopted the left-hand rule. This involved walking until they reached either the boundary of the 'half' of the community or a household that they had seen before, at which point they would turn left. This would create a spiral path covering all of the households in each 'half' of the community.

9. The first household to be sampled along this path was identified using the random number generated in Step 7.

10.Subsequent households were identified by asking the enumerators to skip the number of households calculated in Step 6 as they walked along the spiral path.

It was the responsibility of the survey team supervisors to organize the enumerators along the spiral path to cover the entire 'half' of each village. The same systematic random sampling procedure was adopted for the intervention and comparison communities. In the intervention communities, 40 households were targeted for interview, whilst 44 households were targeted for interview in the comparison communities.

The data for this evaluation were principally collected at the household-level. Questionnaires were conducted with one household member, but they were asked to answer questions for the household as a whole. A household was defined as those individuals who normally (in the last three months) sleep and eat together.

To gain the most accurate picture of the household's situation, the survey team targeted the household head, or their spouse if they were absent at the time the household was sampled, for interview. The household head was defined as the person who mainly makes decisions on the education of children, on household finances and on household expenses. This definition was developed through consultation with Oxfam staff to ensure it was appropriate to the local context. 
In the event that neither the household head nor their spouse was available at the time of the interview, the enumerator was asked to speak to those present at the household to find out when the household head or their spouse would return. The enumerator would then try to organize a suitable time to return for a 'call back'. The enumerator would then return at the designated time. If this process failed first time around, the enumerator had one more attempt to organize a time to interview the household head or their spouse. If, however, after two call backs it was not possible to find the household head or their spouse, the enumerator - with the supervisor's explicit approval - was able to replace the sampled household. The replacement household was simply the next closest household along the spiral path that the enumerator had been walking.

Households were also replaced if they refused to consent to participate in the survey. This was recorded explicitly by the enumerators at the start of the survey.

The numbers of households interviewed in the project communities and the comparison communities are shown in Table 4.2.

Table 4.2: Number of households interviewed in intervention and comparison areas

\begin{tabular}{|c|c|c|c|}
\hline $\begin{array}{l}\text { Intervention / } \\
\text { Comparison }\end{array}$ & Community & $\begin{array}{l}\text { Number of interviews } \\
\text { completed }\end{array}$ & $\begin{array}{l}\text { Number of non- } \\
\text { consenting households }\end{array}$ \\
\hline \multirow{8}{*}{ 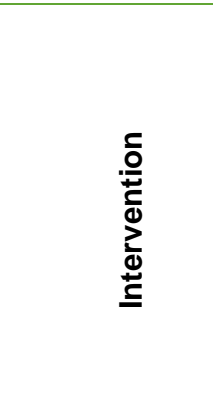 } & Kaalem & 40 & 3 \\
\hline & Kokiselei & 40 & 0 \\
\hline & Loritit & 40 & 3 \\
\hline & Lopusiki & 40 & 1 \\
\hline & Losajait & 40 & 0 \\
\hline & Kobwin & 40 & 1 \\
\hline & Karebur & 40 & 1 \\
\hline & Intervention group total: & 280 & 9 \\
\hline \multirow{13}{*}{ 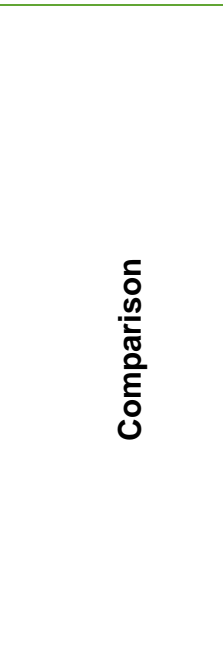 } & Kanagakipur & 45 & 0 \\
\hline & Riokomor & 45 & 1 \\
\hline & Nadunga & 46 & 0 \\
\hline & Milima Tatu & 45 & 1 \\
\hline & Kaeris & 45 & 0 \\
\hline & Namunyanak-Kirionok & 45 & 0 \\
\hline & Morungole & 45 & 5 \\
\hline & Nakalale & 45 & 0 \\
\hline & Kachoda & 46 & 1 \\
\hline & Lolupe & 45 & 2 \\
\hline & Nadwat & 45 & 0 \\
\hline & Lokangae & 43 & 13 \\
\hline & Comparison group total: & 540 & 23 \\
\hline & Full sample total: & 820 & 32 \\
\hline
\end{tabular}

Before the survey started, respondents were given some basic information about the purpose of the survey, to help manage their expectations. The enumerators explained that the survey was being undertaken to help better understand the lives of people in the community, and that it was for 'research purposes only'. It was also made clear that no special support would come to households as a result of the answers to questions in the survey.

Interviews were carried out using mobile devices. The questionnaire was created in a piece of Open Data Kit software, called SurveyCTO, and then downloaded onto a mobile phone given to each enumerator. The functionality of the mobile phones was reduced, so that they could only be used for data collection purposes. The data were uploaded nightly by field supervisors and checked by the evaluation team to ensure high data quality.

Resilience in Kenya: Impact evaluation of Building Resilience in the Arid and Semi-Arid Lands of Northern Kenya. Effectiveness review series 2016-17 
One special feature of this survey was that the specific organization that was mentioned by the enumerator when asking for the respondents' consent at the start of the questionnaire was randomly varied between Oxfam and Ipsos Kenya (the firm that was engaged to assist with the survey work). This was part of an additional research project, which aimed to examine a series of research questions about respondent expectations and data quality. To operationalize this, the specific organization and relevant logo that appeared on the consent form was randomized using the mobile devices. Although the enumerators mentioned only one organization when obtaining respondents' consent, if the respondent asked directly whether Oxfam or Ipsos Kenya were involved in the survey, they were encouraged to answer truthfully that both organizations were involved.

\subsection{ANALYSIS}

Before analysing the effects of the project on resilience outcomes, we compared project participant households and comparison households in terms of their demographic characteristics, livelihoods activities and economic situation in 2012 (that is, before the Building Resilience project began). This helps to check the suitability of the comparison group, and ascertain what variables could be included in the main analysis to control for observable differences between project and non-project households.

Some of the data were based on information recalled during the questionnaire. Before beginning the main part of the questionnaire, the enumerators worked with the respondents to establish a suitable event or season from 2012 to help them to think consistently about the correct time period when answering the recall questions. However, given the difficulties of remembering specific aspects of livelihoods, asset ownership and other activities, it is possible that these recall questions may be subject to measurement error. This should be borne in mind throughout the analysis.

The full comparison of project participant households and comparison households in terms of all these characteristics is shown in Appendix 2. There are four key differences that we wish to highlight.

Firstly, the percentage of households owning any livestock in 2012 appears to be somewhat higher amongst the project households than the comparison households. In the project group, 76 percent of households recalled owning livestock in 2012, compared to 65 percent of comparison households.

Secondly, a greater proportion of project households recalled participating in community-based groups in 2012 than comparison households. This may be a result of previous interventions in the project community, which could have encouraged the formation of community-based groups.

Thirdly, there appears to be a difference in whether the households received remittances in 2012. While 34 percent of project households recalled receiving remittances, the figure was just 20 percent for the comparison households.

Finally, our data suggest that project households owned more small livestock, particularly sheep and goats, than the comparison households in 2012. This difference, together with the difference in the receipt of remittances may help to explain some of the smaller differences in the proportion of households calculated to be in the higher wealth groups in 2012.

Any differences between project and comparison households that existed before the project have the potential to bias comparisons of the project's outcomes between the members of the project and comparison respondents. Therefore, we tried to control for these baseline and demographic differences when making such comparisons. This was especially important for livestock and wealth, which could be regarded as potential outcomes of the project - we hope to 
find out whether the project affected these outcomes, rather than there simply being differences between the project participants and the comparison group.

Some of the differences between the project participant households and the comparison group identified above may be down to recall error. However, this would require the project participants to systematically overstate their livestock and wealth and/or the comparison households to systematically understate. There are two potential reasons this might have happened in our survey. In particular, it may have been difficult for project respondents to remember back to a time before any project activities, so their recall answers may include some mix of their baseline status and the effects of the project.

However, in the absence of these types of systematic biases for the project participant households and comparison households, any measurement error that arises due to recall would actually lead to any differences between project and non-project being underestimated. ${ }^{5}$ Thus, it is unlikely that there are truly no differences between project households and comparison group households, in terms of livestock, remittances or group participation (in 2012). As such, we believe it is important to control for these differences in our analysis.

As described in Section 3, the main approach used in this Effectiveness Review to control for the baseline differences was propensity-score matching (PSM). The variables on which respondents were matched were selected from among the full list detailed in Appendix 2, based on two key factors. Firstly, we selected those variables that were thought to be the most significant in influencing respondents' participation in the project. Secondly, we aimed to include variables that could affect potential project outcomes as well as the likelihood of participating in the project.

After matching, project participant households and comparison households appeared to be reasonably well balanced in terms of each of the selected variables. One caveat is that 13 of the 720 comparison households in the sample had to be dropped from the analysis. However, none of the project households were excluded from the analysis, so the exclusion of only 13 observations at this stage of the analysis is unlikely to make a substantial difference to our main findings.

All the results described in Section 6 of the report were tested for robustness by estimating them with several alternative statistical models, including alternative PSM models and linear or probit regression models. These robustness checks are shown in Appendix 4. However, the results of the alternative PSM and regression models generally produced estimates of outcomes that were similar in magnitude and in statistical significance to those derived from the original PSM model. The few cases where the models produced divergent results are discussed in Section 5, in the text or in endnotes.

As mentioned in Section 3, PSM and regression models can only control for the baseline differences between project and comparison households for which data was collected in the survey. If there are any 'unobserved' differences between the two groups - such as individuals' attitudes or motivation, differences in local leadership, or weather, or other contextual conditions - then these may bias the estimates of outcomes described in Section 5. The evaluation design and the selection of respondents were intended to minimize any potential for unobserved differences, but this possibility cannot be excluded, and must be borne in mind when interpreting the results. 


\section{MEASURING RESILIENCE IN KENYA}

The project under review was specifically aimed at increasing households' resilience. As part of its Global Performance Framework, Oxfam GB has developed an innovative approach to measure the households' resilience to shocks and stress and their ability to adapt to change. This approach involves capturing and aggregating data on various household and community characteristics. In previous Effectiveness Reviews, these characteristics have fallen under five 'dimensions'. ${ }^{6}$ However, the measurement approach taken in this Effectiveness Review instead draws directly on 'The Future is a Choice' - Oxfam's new guidelines for the design and implementation of resilience-building programmes - in which resilience is framed in terms of three overlapping 'capacities'. ${ }^{7}$

Oxfam defines resilience as 'the ability of women and men to realise their rights and improve their well-being despite shocks, stresses and uncertainty'. One reason why measuring resilience is challenging is that we can only really assess whether a system has successfully coped or adapted after the fact.

In this Effectiveness Review, we were partially able to observe how well households had coped with shocks, stresses and uncertainty because certain crises affected communities across Turkana on an annual basis. In particular, at the peak of the dry season, many vulnerable households face severe food insecurity year in year out. As explained in Section 2, these droughts are often accompanied by mass migration, conflict, and sometimes fire. Flash flooding during the wet season also affects communities around the main rivers annually. In Section 6 , we will consider how well households were able to maintain their livestock and crops, and their level of household wealth, in spite of these shocks and stresses.

However, looking at these sorts of final outcomes is not sufficient to tell us about the project's impact on resilience for two main reasons. Firstly, whilst the annual droughts that occurred in the years directly prior to the survey were serious, their effects were not as severe or pervasive as the 2011 East Africa Drought. Therefore, focusing on measures of current well-being would not tell us how resilient households were to relatively large-scale shocks and stresses.

Moreover, looking at previous shocks is retrospective, and does not allow us to investigate the project's impact on resilience in the future.

The 'characteristics approach' to resilience measurement, which we adopt in this section, assumes that there are particular characteristics of households and communities that affect how well they are able to cope with shocks and positively adapt to change. Insofar as there are multiple final well-being outcomes, about which we are ultimately concerned, there should also be a wide range of resilience characteristics. Where possible, we also wish to conceptualize resilience as operating at many different levels (individual, household, community, and so on) as well as for different shocks with different time horizons. Consequently, the number of resilience characteristics is potentially very high. A limitation, of course, is that we do not know for certain how relevant particular characteristics actually are; rather, we assume they are important based on common sense, theory, and an understanding of the local context.

To help structure discussions around the list of characteristics that inform the overall measure of resilience, we used the three interlinked 'capacities', which have recently been developed by Oxfam to guide and influence resilience programming within (and indeed outside) the organization. By drawing on this framework, we ensure that our monitoring and evaluation work is directly linked to the same thinking and understanding behind the design and implementation of Oxfam programmes. The three capacities are presented in Figure 5.1. 


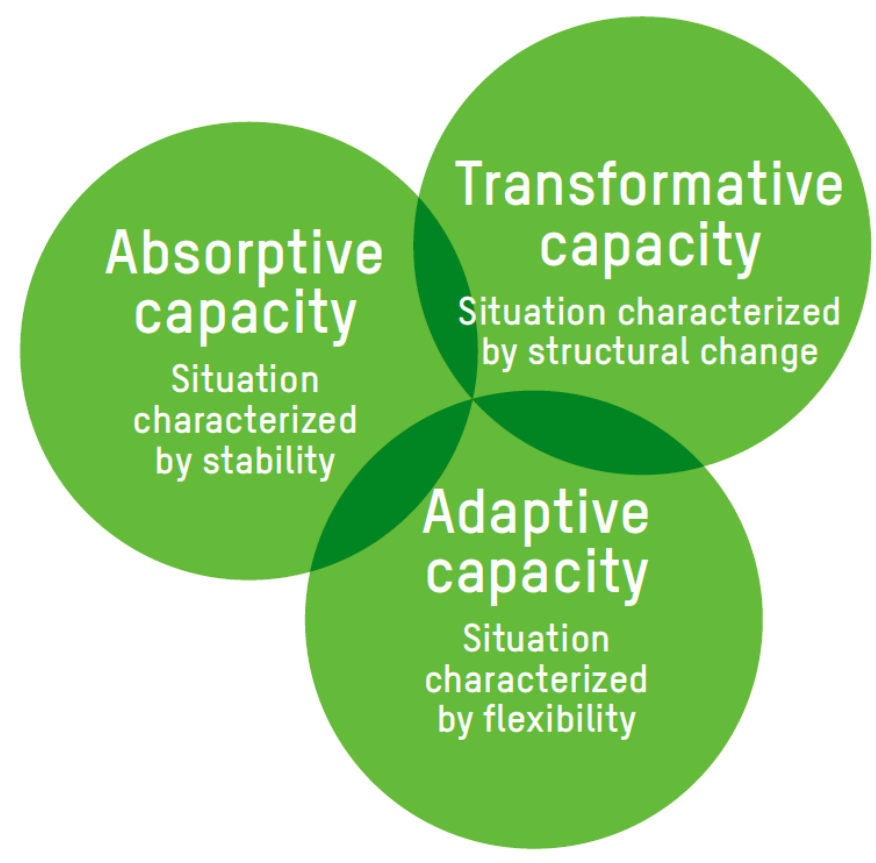

Absorptive capacity is the capacity to take intentional protective action to cope with shocks and stresses. Since shocks and stresses will continue to happen - at least in the medium term - households need to find ways to stabilize their well-being. They can do this in two main ways. Firstly, they may anticipate and reduce the impact of a shock or stress through preparedness or planning, for example, by using early-warning systems or understanding the contents of community contingency plans. Secondly, they may find ways to speed up or improve their recovery after exposure to shocks and stresses, for example by having access to savings, grain banks, or social support networks. As such, absorptive capacity is mainly about the short to medium term.

Adaptive capacity is the capacity to make intentional incremental adjustments in anticipation of or in response to change. This enables households to be more flexible in their responses to shocks, stresses and uncertainty. Adaptive capacity relies heavily on learning from previous crises, so households' understanding of patterns of shocks and stresses relates to factors such as understanding of climate change and access to price and market information. Additionally, households need to be able to make certain investments in order to adapt, so access to credit or other streams of reliable income (such as formal employment or remittances) may boost adaptive capacity. Extra opportunities for adaptation, such as through state extension services or access to markets, may also better enable households to adapt. Adaptive capacity applies principally to the medium term.

Transformative capacity is the capacity to make intentional change to stop or reduce the drivers of risk, vulnerability and inequality. Transformative capacity is therefore about effecting long-term change, altering the stream of shocks and stresses and the uncertainty faced by the poor. This often relies on transforming the systems that drive risk and vulnerability, including intra-household gender dynamics, local governments, and even eco-systems. As a result, transformative capacity strongly emphasizes the need to think about resilience at many different scales. Shifting attitudes towards new innovations and the division of labour within the households can play a role in transformative capacity. Transformation may also depend on interactions between individuals, such as through community groups or formal government channels.

While the three capacities of resilience described here provide an overall framework, the challenge in creating a measure of resilience is to identify specific characteristics that are appropriate to the local context. For this Effectiveness Review, we consulted local Oxfam staff 
to identify what factors they considered the most important for contributing towards resilience within the project area. Two focus groups were then carried out, one entirely comprised of women and one entirely comprised of men, in a community that was similar to those included in the survey. ${ }^{8}$ This enabled us to further probe people's understanding of the factors that contributed to their resilience.

For this Effectiveness Review, we were also able to draw on the Community-Based Resilience Analysis (CoBRA) research project, which was implemented by the United Nations Development Programme (UNDP) Drylands Development Centre in 2014. The CoBRA project used several qualitative data collection techniques - including focus group discussions and key informant interviews - to identify and prioritize characteristics of resilience (as well as ways to monitor and address community-specific constraints on resilience). ${ }^{9}$ This provided an additional source from which we could draw resilience indicators that were relevant to the Turkana context.

This process led to a set of characteristics of resilience being identified, listed in Table 5.1. It is important to note at this stage that while not all characteristics considered in this Effectiveness Review may directly be linked to the project activities, all are deemed to be important to a household's overall resilience in this particular context. The right-hand column of Table 5.1 shows the characteristics on which the project was expected to have an impact, given its Logic Model.

Table 5.1: Characteristics of resilience examined in this Effectiveness Review

\begin{tabular}{|c|c|c|}
\hline Capacity & Characteristic & $\begin{array}{l}\text { Connected to } \\
\text { project logic? }\end{array}$ \\
\hline \multirow{10}{*}{ Absorptive } & Livelihood diversity & Yes \\
\hline & Livestock diversity & No \\
\hline & Herd size & No \\
\hline & Access to drinking water & No \\
\hline & Access to water for livestock & No \\
\hline & Awareness of the community contingency plan & Yes \\
\hline & Savings & Yes \\
\hline & Access to early-warning information & Yes \\
\hline & Access to back-up food supplies & No \\
\hline & Dietary diversity & Yes \\
\hline \multirow{7}{*}{ Adaptive } & Remittances or formal earnings & No \\
\hline & Access to credit & Yes \\
\hline & Education of household members & Yes \\
\hline & Growth of fruits/vegetables & Yes \\
\hline & Access to markets & No \\
\hline & Experience of disputes over resources & No \\
\hline & Ownership of productive assets & Yes \\
\hline \multirow{9}{*}{ Transformative } & Attitude to change & No \\
\hline & Adoption of innovative practices & Yes \\
\hline & $\begin{array}{l}\text { Involvement in community-level disaster } \\
\text { management }\end{array}$ & Yes \\
\hline & Capacity of CDMCs & Yes \\
\hline & Participation in community groups & Yes \\
\hline & Voice of women in the community & Yes \\
\hline & County/national integration of community plans & Yes \\
\hline & $\begin{array}{l}\text { Ability to make complaints/hold government to } \\
\text { account }\end{array}$ & Yes \\
\hline & Voice of disabled in the community & Yes \\
\hline
\end{tabular}

Resilience in Kenya: Impact evaluation of Building Resilience in the Arid and Semi-Arid Lands of Northern 
The questionnaire used in the Effectiveness Review included questions relating to each of the characteristics listed in Table 5.1.

Data from these various indicators of resilience were aggregated using an approach similar to the Alkire-Foster method, adapted from the methodology used by the Oxford Poverty and Human Development Institute for measuring multidimensional constructs, such as poverty and women's empowerment. For each characteristic, a benchmark was defined based on what it means for a household to be faring reasonably well in relation to the characteristic in question. The particular benchmarks used for each characteristic are detailed in Appendix 1. For example, each household was defined as scoring positively in terms dietary diversity if household members consumed a carbohydrate source on each day of the seven days preceding the survey, a protein source on at least three of those days, and vegetables on at least one of those days. These cut-offs were developed through conversations with project staff and by checking the summary statistics for each variable to ensure the proposed thresholds were not obscuring important variation in the data. There is, however, inevitably, a degree of arbitrariness in defining such cut-offs. Alternative cut-offs and formulations of the indicators were tested as a check on the robustness of the results obtained from applying the cut-offs.

Having used the cut-offs to create a binary variable for each characteristic of resilience, it was then necessary to find some way of aggregating across all the indicators of resilience. One of the biggest challenges in constructing this type of index is finding ways to weight different indicators - or indeed different capacities - against one another to construct an index that adequately reflects what is important for resilience in the local context. We adopt two different strategies for assigning weights to the indicators in this Effectiveness Review, to try and ensure that our findings are not sensitive to different assumptions about what truly matters for resilience.

Firstly, in line with previous Effectiveness Reviews, we weight the indicators equally, by simply counting the proportion of characteristics in which the household scored positively. We refer to this measure as the base resilience index. Secondly, we create an index that is based on the idea of giving equal weight to each of the three resilience capacities. To do this we first created a separate index for each capacity by counting the proportion of indicators under that capacity in which the household scored positively. Then we took the average across these capacityspecific indices to give an overall resilience index. We refer to this as the equal capacities resilience index.$^{10}$ The project's effect on resilience, as measured through these indices, is reported in Section 6.9.

One issue with creating an overall index for resilience in this way is that we are implicitly assuming that the specific resilience characteristics, and indeed resilience capacities, can easily be substituted for one another. ${ }^{11}$ Since the overall resilience index simply takes the average of the resilience characteristics across the three capacities, a slight loss in transformative capacity, say, can be compensated by a slight increase in absorptive or adaptive capacity. To address this issue, we also display the capacity-specific indices separately in Section 6.9 to illustrate how the different capacities were affected by the project. 
This report is intended to be free from excessive technical jargon, with more detailed technical information being reserved for the appendixes and endnotes. However, there are some statistical concepts that cannot be avoided when discussing the results. In this report, results will usually be stated as the average difference between the project households (that is referred to as the 'intervention' group) and the matched non-project households (named the 'comparison' group). In the tables of results on the following pages, statistical significance will be indicated with asterisks, with three asterisks $\left.{ }^{* \star *}\right)$ indicating a $p$-value of less than 1 percent, two asterisks $\left(^{* *}\right)$ indicating a $p$-value of less than 5 percent and one asterisk $\left(^{*}\right)$ indicating a $p$ value of less than 10 percent. The higher the $p$-value, the less confident we are that the measured estimate reflects the true impact, as opposed to simply random variation in the data. Results with a $p$-value of more than 10 percent are not considered to be statistically significant.

\subsection{INTRODUCTION}

This section presents a comparison of the households interviewed in project and comparison communities in terms of various outcome measures relating to the project under review. As described above, asterisks are used in the results tables to indicate where the differences are statistically significant at least the 10 percent significance level.

The results are shown after correcting for observed baseline differences between the households interviewed in the project communities and those in the comparison communities using a propensity-score matching (PSM) procedure. This means that when we report differences in the means for the intervention group outcomes and comparison group outcomes, this is for the matched sample. More information about the procedure applied is found in Appendix 3. All outcomes discussed here have also been tested for robustness with alternative statistical models, as described in Appendix 4; where those alternative models produce markedly different results from those shown in the tables in this section, this is discussed in the text or in endnotes.

There is a key limitation to our analysis, which has been described above, but is repeated here because it affects the interpretation of our results. There may be 'non-observable' differences between the project participants and comparison households - such as individuals' attitudes or motivation, differences in local leadership, weather or other contextual conditions. If these unobserved differences also influence the potential outcomes we consider in this section, then our estimates of the project's effects will be biased. This possibility must be borne in mind when interpreting the results.

\subsection{INVOLVEMENT IN PROJECT ACTIVITIES}

The first step in understanding the project's impact is to examine the extent to which respondents reported having received the types of support and having participated in the various activities implemented by the project.

In Table 6.1, we show the differences between the project participant households and the comparison households in terms of their participation in community groups. Respondents were asked whether they, or any member of their household, attended meetings of a series of community groups at the time of the survey. We first show an indicator for whether or not the household participates in any community groups in Column 1, followed by the number of 
community groups in which the household participated in Column 2. The remaining columns report whether household members participate in specific types of community groups.

\section{Table 6.1: Participation in community groups}

Part A

\begin{tabular}{|l|l|l|l|l|}
\hline & $\mathbf{1}$ & $\mathbf{2}$ & $\mathbf{3}$ & $\mathbf{4}$ \\
\hline & $\begin{array}{l}\text { Household } \\
\text { member(s) } \\
\text { participate in any } \\
\text { community groups }\end{array}$ & $\begin{array}{l}\text { Number of } \\
\text { community } \\
\text { groups in which } \\
\text { household } \\
\text { participates }\end{array}$ & $\begin{array}{l}\text { Household } \\
\text { member(s) } \\
\text { participate in } \\
\text { disaster } \\
\text { management } \\
\text { committee }\end{array}$ & $\begin{array}{l}\text { Household } \\
\text { member(s) } \\
\text { participate in } \\
\text { women's group }\end{array}$ \\
\hline $\begin{array}{l}\text { Intervention } \\
\text { group mean }\end{array}$ & 0.49 & 0.89 & 0.19 & 0.22 \\
\hline $\begin{array}{l}\text { Comparison } \\
\text { group mean }\end{array}$ & 0.49 & 0.89 & 0.13 & 0.25 \\
\hline Difference: & -0.00 & -0.01 & $0.06 * *$ & -0.03 \\
\hline $\begin{array}{l}\text { Observations } \\
\text { (intervention } \\
\text { group) }\end{array}$ & 280 & $(0.10)$ & $0.03)$ & $(0.03)$ \\
\hline $\begin{array}{l}\text { Observations } \\
\text { (total) }\end{array}$ & 807 & 280 & 280 & 280 \\
\hline
\end{tabular}

\section{Part B}

\begin{tabular}{|l|l|l|l|l|}
\hline & $\mathbf{5}$ & $\mathbf{6}$ & $\mathbf{7}$ & $\mathbf{8}$ \\
\hline & $\begin{array}{l}\text { Household } \\
\text { member(s) } \\
\text { participate in } \\
\text { livestock } \\
\text { committee }\end{array}$ & $\begin{array}{l}\text { Household } \\
\text { member(s) } \\
\text { participate in } \\
\text { peace building }\end{array}$ & $\begin{array}{l}\text { Household } \\
\text { member(s) } \\
\text { participate in } \\
\text { savings group }\end{array}$ & $\begin{array}{l}\text { Household } \\
\text { member(s) } \\
\text { participate in } \\
\text { groups for } \\
\text { disability }\end{array}$ \\
\hline $\begin{array}{l}\text { Intervention } \\
\text { group mean }\end{array}$ & 0.06 & 0.12 & 0.08 & 0.03 \\
\hline $\begin{array}{l}\text { Comparison } \\
\text { group mean }\end{array}$ & 0.08 & 0.07 & 0.11 & 0.01 \\
\hline Difference: & -0.02 & $0.05^{*}$ & -0.03 & $0.02^{*}$ \\
\hline $\begin{array}{l}\text { Observations } \\
\text { (intervention }\end{array}$ & 280 & $(0.02)$ & $(0.02)$ & $(0.01)$ \\
\hline $\begin{array}{l}\text { Oboup) } \\
\text { (total) }\end{array}$ & 280 & 280 & 280 \\
\hline
\end{tabular}

Standard errors in parentheses; * $p<0.1,{ }^{* *} p<0.05,{ }^{* * *} p<0.01$; PSM estimates are bootstrapped with 1,000 repetitions.

Overall, 49 percent of both project and comparison households reported participating in at least one community group. For the matched sample, the recalled baseline data suggest that approximately 35 percent of households participated in at least one community group (see Appendix 3). It is important to note that, as we explained in Section 4, our analysis controls directly for baseline differences in group participation using data recalled back to 2012. Thus, it appears that while there has been an increase in project households participating in groups, the same has also occurred among comparison households, meaning that we cannot be sure that this project alone has contributed to the increase.

Though there are no differences between the overall household participation in groups, some differences do emerge when we look at the specific community groups. 
As would be expected, the largest difference between the intervention and comparison groups arises in terms of participation in a Community Disaster Management Committee (CDMC). As we see in Column 3, 19 percent of the participant households in our matched sample reported having a member involved in a CDMC, compared to 13 percent of the comparison households.

If we examine the underlying data (not shown in the table) further, a higher proportion of project households reported being aware of a community disaster-management plan - 27 percent, compared to 13 percent of matched comparison household, a more striking difference. It is also worth noting that the higher levels of group participation among the project participant households observed in Table 6.1 are not restricted to the CDMCs. Indeed, there are differences in terms of participation in peace-building groups and groups for people living with disabilities. While the differences are small, there is some evidence that these reflect project activities - particularly as two of the stated project outcomes were to engage in peace building and conflict prevention, as well as contributing to enable people to claim their rights to basic services.

Table 6.2: Trainings

\begin{tabular}{|c|c|c|c|c|}
\hline & 1 & 2 & 3 & 4 \\
\hline & $\begin{array}{l}\text { Household } \\
\text { member(s) trained } \\
\text { in livestock health }\end{array}$ & $\begin{array}{l}\text { Household } \\
\text { member(s) } \\
\text { trained in } \\
\text { management of } \\
\text { pasture lands }\end{array}$ & $\begin{array}{l}\text { Household } \\
\text { member(s) } \\
\text { trained in drought } \\
\text { preparedness }\end{array}$ & $\begin{array}{l}\text { Household } \\
\text { member(s) } \\
\text { trained in } \\
\text { improved farming } \\
\text { techniques }\end{array}$ \\
\hline $\begin{array}{l}\text { Intervention } \\
\text { group mean }\end{array}$ & 0.52 & 0.38 & 0.53 & 0.34 \\
\hline $\begin{array}{l}\text { Comparison } \\
\text { group mean }\end{array}$ & 0.37 & 0.24 & 0.35 & 0.22 \\
\hline \multirow[t]{2}{*}{ Difference: } & $0.15^{\star * *}$ & $0.15^{\star * *}$ & $0.19^{* * *}$ & $0.12^{\star * *}$ \\
\hline & $(0.04)$ & $(0.04)$ & $(0.04)$ & $(0.03)$ \\
\hline $\begin{array}{l}\text { Observations } \\
\text { (intervention } \\
\text { group) }\end{array}$ & 280 & 280 & 280 & 280 \\
\hline $\begin{array}{l}\text { Observations } \\
\text { (total) }\end{array}$ & 807 & 807 & 807 & 807 \\
\hline
\end{tabular}

\begin{tabular}{|l|l|l|l|l|}
\hline & $\mathbf{5}$ & $\mathbf{6}$ & $\mathbf{7}$ & $\mathbf{8}$ \\
\hline & $\begin{array}{l}\text { Household } \\
\text { member(s) trained } \\
\text { in } \\
\text { marketing/selling } \\
\text { livestock }\end{array}$ & $\begin{array}{l}\text { Household } \\
\text { member(s) } \\
\text { trained in } \\
\text { financial } \\
\text { management }\end{array}$ & $\begin{array}{l}\text { Household } \\
\text { member(s) } \\
\text { trained in } \\
\text { household } \\
\text { business }\end{array}$ & $\begin{array}{l}\text { Household } \\
\text { member(s) } \\
\text { trained in gender } \\
\text { issues }\end{array}$ \\
\hline $\begin{array}{l}\text { Intervention } \\
\text { group mean }\end{array}$ & 0.30 & 0.26 & 0.41 & 0.27 \\
\hline $\begin{array}{l}\text { Comparison } \\
\text { group mean }\end{array}$ & 0.22 & 0.19 & 0.28 & 0.15 \\
\hline Difference: & $0.09^{* *}$ & $0.08^{* *}$ & $0.13^{\star * *}$ & $0.12^{* * *}$ \\
\hline $\begin{array}{l}\text { Observations } \\
\text { intervention } \\
\text { group) }\end{array}$ & 280 & $(0.03)$ & $(0.04)$ & $(0.03)$ \\
\hline $\begin{array}{l}\text { Observations } \\
\text { (total) }\end{array}$ & 807 & 280 & 280 & 280 \\
\hline
\end{tabular}




\begin{tabular}{|l|l|l|l|l|}
\hline & $\mathbf{9}$ & $\mathbf{1 0}$ & $\mathbf{1 1}$ & $\mathbf{1 2}$ \\
\hline & $\begin{array}{l}\text { Household } \\
\text { member(s) trained } \\
\text { in making } \\
\text { complaints }\end{array}$ & $\begin{array}{l}\text { Household } \\
\text { member(s) } \\
\text { trained in hazards }\end{array}$ & $\begin{array}{l}\text { Household } \\
\text { member(s) } \\
\text { trained in } \\
\text { claiming goods } \\
\text { and services }\end{array}$ & $\begin{array}{l}\text { Household } \\
\text { member(s) } \\
\text { trained in } \\
\text { advocacy }\end{array}$ \\
\hline $\begin{array}{l}\text { Intervention } \\
\text { group mean }\end{array}$ & 0.17 & 0.22 & 0.16 & 0.15 \\
\hline $\begin{array}{l}\text { Comparison } \\
\text { group mean }\end{array}$ & 0.05 & 0.11 & 0.06 & 0.05 \\
\hline Difference: & $0.12^{* * *}$ & $0.11^{* * *}$ & $0.09^{* * *}$ & $0.10^{* * *}$ \\
\hline $\begin{array}{l}\text { Observations } \\
\text { (intervention } \\
\text { group) }\end{array}$ & 280 & $(0.03)$ & $(0.03)$ & $(0.02)$ \\
\hline $\begin{array}{l}\text { Observations } \\
\text { (total) }\end{array}$ & 807 & 280 & 280 & 280 \\
\hline
\end{tabular}

Standard errors in parentheses; * $p<0.1,{ }^{* *} p<0.05,{ }^{* * *} p<0.01$; PSM estimates are bootstrapped with 1,000 repetitions.

In Tables 6.2 and 6.3, we show a series of results indicating the types of activities that were undertaken in communities by external actors. Respondents were asked whether certain activities had been carried out in their communities since 2012, that is, over the entire duration of the project.

Table 6.2 shows the differences between intervention and comparison households in terms of the training in which they participated during the life of the project. There are positive and significant differences in favour of the project across all the different trainings considered in the survey.

Some of the largest differences are for training in drought preparedness, where 53 percent of project households reported receiving such training compared to 35 percent of non-project households, as well as training in livestock health (52 percent compared to 37 percent) and management of pasture lands (38 percent compared to 24 percent).

Particularly striking are the results reported in columns $8-12$, including the proportion of households trained in gender issues, where 27 percent of project households received such training compared to 15 percent of non-project households. While the proportion of households receiving training in making complaints, claiming goods and/or services, and advocacy is smaller than for the other training topics, there are positive and significant differences between the project and non-project households. Only a very small proportion of non-project households reported receiving such trainings.

Therefore, taking the results from Table 6.2 together, the intervention group - as expected clearly participated in more activities that were implemented by the project than the comparison group. 
Table 6.3: Activities carried out in the community

\begin{tabular}{|l|l|l|l|l|}
\hline & $\mathbf{1}$ & $\mathbf{2}$ & $\mathbf{3}$ & $\mathbf{4}$ \\
\hline & $\begin{array}{l}\text { Rehab of } \\
\text { boreholes }\end{array}$ & $\begin{array}{l}\text { Construction of } \\
\text { toilet }\end{array}$ & $\begin{array}{l}\text { Construction of } \\
\text { school }\end{array}$ & $\begin{array}{l}\text { Construction of } \\
\text { hospital }\end{array}$ \\
\hline $\begin{array}{l}\text { Intervention } \\
\text { group mean }\end{array}$ & 0.78 & 0.22 & 0.82 & 0.73 \\
\hline $\begin{array}{l}\text { Comparison } \\
\text { group mean }\end{array}$ & 0.75 & 0.42 & 0.85 & 0.70 \\
\hline Difference: & 0.03 & $-0.20^{\star \star \star}$ & -0.03 & 0.03 \\
\hline $\begin{array}{l}\text { Observations } \\
\text { (intervention } \\
\text { group) }\end{array}$ & 280 & $(0.04)$ & $(0.03)$ & $0.04)$ \\
\hline $\begin{array}{l}\text { Observations } \\
\text { (total) }\end{array}$ & 807 & 280 & 280 & 280 \\
\hline
\end{tabular}

\begin{tabular}{|c|c|c|c|}
\hline & 5 & 6 & 7 \\
\hline & $\begin{array}{l}\text { Construction of } \\
\text { irrigation }\end{array}$ & $\begin{array}{l}\text { Construction of } \\
\text { fish processing }\end{array}$ & $\begin{array}{l}\text { Provision of back- } \\
\text { up food }\end{array}$ \\
\hline $\begin{array}{l}\text { Intervention } \\
\text { group mean }\end{array}$ & 0.28 & 0.09 & 0.45 \\
\hline $\begin{array}{l}\text { Comparison } \\
\text { group mean }\end{array}$ & 0.23 & 0.09 & 0.37 \\
\hline \multirow[t]{2}{*}{ Difference: } & 0.05 & -0.00 & $0.08^{\star \star}$ \\
\hline & $(0.03)$ & $(0.02)$ & $(0.04)$ \\
\hline $\begin{array}{l}\text { Observations } \\
\text { (intervention } \\
\text { group) }\end{array}$ & 280 & 280 & 280 \\
\hline $\begin{array}{l}\text { Observations } \\
\text { (total) }\end{array}$ & 807 & 807 & 807 \\
\hline
\end{tabular}

Standard errors in parentheses; * $p<0.1,{ }^{* *} p<0.05,{ }^{* * *} p<0.01$; PSM estimates are bootstrapped with 1,000 repetitions.

Finally, we report in Table 6.3 the differences between project and comparison communities in terms of particular activities carried out in the community since 2012 (based on households' responses). The results show that there are no clear differences between the project and comparison communities in terms of the following activities; rehabilitation of boreholes, construction of schools, hospitals, irrigation schemes or fish-processing facilities. The results, however, suggest a greater incidence of toilet construction in the comparison communities, and there is some evidence that the provision of back-up food supplies was higher among project communities than comparison communities.

\subsection{LIVESTOCK}

In this section, we examine how the project influenced households' ownership of livestock. Livestock not only provides households with alternative sources of food and income - through, for example, the production of milk and eggs - but also enables households to undertake agricultural activities more effectively - by helping to plough fields, transport agricultural output, and so on. Additionally, livestock can be sold to support incomes directly.

In Table 6.4 we present the differences between the project and non-project households in terms of overall livestock ownership. The results in Column 1 suggest that the project has had a small but statistically significant effect on whether households owned livestock. Approximately 82 percent of project households owned livestock at the time of the survey, compared with 74 percent of comparison households. Thus, the vast majority of sampled households owned some 
type of livestock. In Column 2 we can see, however, that there were no significant differences in terms of the number of types of animals owned in project and non-project households.

Table 6.4: Overall livestock ownership

\begin{tabular}{|c|c|c|c|c|c|}
\hline & 1 & 2 & 3 & 4 & 5 \\
\hline & $\begin{array}{l}\text { Household } \\
\text { owned any } \\
\text { livestock }\end{array}$ & $\begin{array}{l}\text { Number of } \\
\text { types of } \\
\text { animals owned }\end{array}$ & $\begin{array}{l}\text { Women mainly } \\
\text { responsible for } \\
\text { any types of } \\
\text { animal }\end{array}$ & $\begin{array}{l}\text { Number of } \\
\text { animal types } \\
\text { for which } \\
\text { women were } \\
\text { mainly } \\
\text { responsible }\end{array}$ & $\begin{array}{l}\text { Proportion of } \\
\text { animal types } \\
\text { for which } \\
\text { women were } \\
\text { mainly } \\
\text { responsible }\end{array}$ \\
\hline $\begin{array}{l}\text { Intervention } \\
\text { group mean }\end{array}$ & 0.82 & 1.63 & 0.13 & 0.17 & 0.11 \\
\hline $\begin{array}{l}\text { Comparison } \\
\text { group mean }\end{array}$ & 0.74 & 1.53 & 0.11 & 0.14 & 0.11 \\
\hline \multirow[t]{2}{*}{ Difference: } & $0.08^{* *}$ & 0.10 & 0.01 & 0.04 & -0.01 \\
\hline & $(0.03)$ & $(0.09)$ & $(0.03)$ & $(0.04)$ & $(0.03)$ \\
\hline $\begin{array}{l}\text { Observations } \\
\text { (intervention } \\
\text { group) }\end{array}$ & 280 & 280 & 280 & 280 & 229 \\
\hline $\begin{array}{l}\text { Observations } \\
\text { (total) }\end{array}$ & 807 & 807 & 807 & 807 & 583 \\
\hline
\end{tabular}

Standard errors in parentheses; ${ }^{*} p<0.1,{ }^{* *} p<0.05,{ }^{* * *} p<0.01$; PSM estimates are bootstrapped with 1,000 repetitions.

In Columns 3, 4 and 5 we explore whether women in project households had more responsibility for looking after livestock than comparison households. For each type of animal owned, households were asked which household members were mainly responsible for looking after that animal - these results relate to those animals for which female members were 'mainly responsible'. Across Columns 3, 4 and 5 we report whether or not women were mainly responsible for any animal types, the number of types for which they were responsible, and the proportion of animal types owned for which they were responsible (respectively). However, the project did not appear to have statistically significant effects on women's responsibility for livestock.

In Table 6.5 we report the number of each type of animal owned by project and non-project households. From the results presented, the project did not appear to have a statistically significant effect on the number of different livestock owned by the household. Although there are some small differences in favour of the project households - particularly in the number of cows - the difference is not statistically significant, and therefore we cannot be confident that this is not just due to random variation in the data.

It should be noted that the table clearly shows that goats are the predominant livestock kept by households in the project communities - with an average of 27 in each project household. The number of sheep, by comparison, averaged five per project household, while the average number of cows, camels and poultry owned by the household was less than one in each case. 
Table 6.5: Numbers of each animal owned

\begin{tabular}{|l|l|l|l|l|l|}
\hline & $\mathbf{1}$ & $\mathbf{2}$ & $\mathbf{3}$ & $\mathbf{4}$ & $\mathbf{5}$ \\
\hline & Cows & Sheep & Camels & Goats & Poultry \\
\hline $\begin{array}{l}\text { Intervention } \\
\text { group mean }\end{array}$ & 0.37 & 5.16 & 0.45 & 26.79 & 0.87 \\
\hline $\begin{array}{l}\text { Comparison } \\
\text { group mean }\end{array}$ & 0.26 & 4.99 & 0.52 & 25.86 & 0.83 \\
\hline Difference: & 0.12 & 0.17 & -0.07 & 0.94 & 0.04 \\
\hline $\begin{array}{l}\text { Observations } \\
\text { (intervention } \\
\text { group) }\end{array}$ & 280 & $(0.88)$ & $(0.17)$ & $(3.48)$ & $(0.21)$ \\
\hline $\begin{array}{l}\text { Observations } \\
\text { (total) }\end{array}$ & 807 & 280 & 280 & 280 & 280 \\
\hline
\end{tabular}

Standard errors in parentheses; ${ }^{*} p<0.1,{ }^{* *} p<0.05,{ }^{* * *} p<0.01$; PSM estimates are bootstrapped with 1,000 repetitions.

Therefore, the results for livestock ownership are mixed. The project led to a modest increase in the likelihood that households owned livestock; however, there was no clear evidence that the project raised women's responsibility for animals within the household, or led to an increase in the number of animals owned.

In Table 6.6 we report whether the household sold livestock in the year prior to the survey, and whether they sold in the dry or rainy season, as well as where they sold their livestock.

Table 6.6: Livestock sales

\begin{tabular}{|c|c|c|c|c|c|}
\hline & 1 & 2 & 3 & 4 & 5 \\
\hline & $\begin{array}{l}\text { Household } \\
\text { sold livestock } \\
\text { in the past } \\
\text { year }\end{array}$ & $\begin{array}{l}\text { Household } \\
\text { sold livestock } \\
\text { in the dry } \\
\text { season }\end{array}$ & $\begin{array}{l}\text { Household } \\
\text { sold livestock } \\
\text { in the rainy } \\
\text { season }\end{array}$ & $\begin{array}{l}\text { Household } \\
\text { sold livestock } \\
\text { in the } \\
\text { community }\end{array}$ & $\begin{array}{l}\text { Household } \\
\text { sold livestock } \\
\text { outside of } \\
\text { their } \\
\text { community }\end{array}$ \\
\hline $\begin{array}{l}\text { Intervention } \\
\text { group mean }\end{array}$ & 0.40 & 0.33 & 0.13 & 0.24 & 0.23 \\
\hline $\begin{array}{l}\text { Comparison } \\
\text { group mean }\end{array}$ & 0.39 & 0.34 & 0.15 & 0.27 & 0.21 \\
\hline \multirow[t]{2}{*}{ Difference: } & 0.01 & -0.02 & -0.02 & -0.03 & 0.02 \\
\hline & $(0.04)$ & $(0.04)$ & $(0.03)$ & $(0.04)$ & $(0.03)$ \\
\hline $\begin{array}{l}\text { Observations } \\
\text { (intervention } \\
\text { group) }\end{array}$ & 279 & 280 & 280 & 280 & 280 \\
\hline $\begin{array}{l}\text { Observations } \\
\text { (total) }\end{array}$ & 805 & 807 & 807 & 807 & 807 \\
\hline
\end{tabular}

Standard errors in parentheses; * $p<0.1,{ }^{* *} p<0.05,{ }^{* * *} p<0.01$; PSM estimates are bootstrapped with 1,000 repetitions.

As can be seen from the table, the results for both project and comparison households are very similar, with no statistically significant differences for any of the measures, indicating that there is no clear evidence the project affected these aspects of livestock sales. It is interesting to note that 40 percent of project household reported selling livestock in the previous year, with most of the sales - perhaps as expected - occurring in dry season. The proportion of sales happening inside or outside of the community was broadly similar.

Table 6.7 reports on whether there were underlying problems or barriers to the household in selling their livestock during the previous 12 months. Three specific barriers were examined whether the livestock were too weak to buy or to move to market and whether the household 
thought that potential markets were too far away. The results only include those households who reported that they tried to sell livestock in the previous 12 months. From the results presented, the project did not appear to have a statistically significant effect on reducing these perceived barriers or problems for households wishing to sell their livestock. It is interesting to note that just over half of project households reported that the weakness of their livestock made it difficult to sell, and 76 percent of households reported that distance to market was a problem.

Table 6.7: Experience of problems when trying to sell livestock

\begin{tabular}{|l|l|l|l|}
\hline & $\mathbf{1}$ & $\mathbf{2}$ & $\mathbf{3}$ \\
\hline & $\begin{array}{l}\text { Livestock too } \\
\text { weak to buy }\end{array}$ & $\begin{array}{l}\text { Livestock too } \\
\text { weak to move }\end{array}$ & $\begin{array}{l}\text { Markets too } \\
\text { far away }\end{array}$ \\
\hline $\begin{array}{l}\text { Intervention } \\
\text { group mean }\end{array}$ & 0.52 & 0.52 & 0.76 \\
\hline $\begin{array}{l}\text { Comparison } \\
\text { group mean }\end{array}$ & 0.49 & 0.48 & 0.73 \\
\hline Difference: & 0.02 & 0.04 & 0.04 \\
\hline $\begin{array}{l}\text { Observations } \\
\text { (intervention } \\
\text { group) }\end{array}$ & 128 & $(0.06)$ & $(0.05)$ \\
\hline $\begin{array}{l}\text { Observations } \\
\text { (total) }\end{array}$ & 337 & 128 & 128 \\
\hline
\end{tabular}

Standard errors in parentheses; ${ }^{*} p<0.1,{ }^{* *} p<0.05,{ }^{* * *} p<0.01$; PSM estimates are bootstrapped with 1,000 repetitions.

Finally, we consider whether there were any differences between project and comparison households experiencing livestock loss due to various factors. Looking only at those households that experienced loss of livestock, Table 6.8 reports the proportion of livestock loss due to drought, flood, disease and theft. It is apparent that drought and disease are the main causes of loss in project households.

Table 6.8: Loss of livestock

\begin{tabular}{|l|l|l|l|l|}
\hline & $\mathbf{1}$ & $\mathbf{2}$ & $\mathbf{3}$ & $\mathbf{4}$ \\
\hline & $\begin{array}{l}\text { Household } \\
\text { experienced } \\
\text { livestock loss } \\
\text { due to } \\
\text { drought }\end{array}$ & $\begin{array}{l}\text { Household } \\
\text { experienced } \\
\text { livestock loss } \\
\text { due to flood }\end{array}$ & $\begin{array}{l}\text { Household } \\
\text { experienced } \\
\text { livestock loss } \\
\text { due to } \\
\text { disease }\end{array}$ & $\begin{array}{l}\text { Household } \\
\text { experienced } \\
\text { livestock loss } \\
\text { due to theft }\end{array}$ \\
\hline $\begin{array}{l}\text { Intervention } \\
\text { group mean }\end{array}$ & 0.74 & 0.14 & 0.74 & 0.43 \\
\hline $\begin{array}{l}\text { Comparison } \\
\text { group mean }\end{array}$ & 0.81 & 0.17 & 0.77 & 0.41 \\
\hline \begin{tabular}{l} 
Difference: \\
\hline Observations
\end{tabular} & -0.06 & -0.03 & -0.03 & 0.02 \\
\hline $\begin{array}{l}\text { intervention } \\
\text { group) }\end{array}$ & 212 & $(0.04)$ & $(0.04)$ & $(0.05)$ \\
\hline $\begin{array}{l}\text { Observations } \\
\text { (total) }\end{array}$ & 544 & 212 & 212 & 212 \\
\hline
\end{tabular}

Standard errors in parentheses; * $p<0.1,{ }^{* *} p<0.05,{ }^{* * *} p<0.01$; PSM estimates are bootstrapped with 1,000 repetitions.

With no significant differences between project and comparison households in these results, there is no clear evidence to suggest the project has reduced the effects on livestock loss from these causes. 


\subsection{CROPS}

In this section, we consider the project's impact on farming practices. We first outline the project's overall impact on crop growing, highlighting how women's responsibility for crop cultivation and crop sales changed.

We start by reporting households' overall engagement in agricultural activities (Table 6.9). Among the sample of project households, 30 percent reported growing any crops in the year prior to the survey, compared to 22 percent of the matched comparison sample. This difference suggests that the project has had a small but statistically significant effect on whether households practised crop cultivation. It is important to note that only 31 percent of project households reported having any of their own enclosed land.

On the issue of land, the project also appears to have had a positive effect on the amount of land households own. As the matching models controlled for differences in land ownership at baseline (2012), it appears that the project may have had some influence in households increasing their ownership of land. Project households own approximately 0.25 more acres than their non-project comparators.

Table 6.9: Overall engagement in agricultural activities

\begin{tabular}{|c|c|c|c|c|}
\hline & 1 & 2 & 3 & 4 \\
\hline & $\begin{array}{l}\text { Household grew } \\
\text { any crops in the } \\
\text { past year }\end{array}$ & $\begin{array}{l}\text { Number of acres } \\
\text { the household } \\
\text { owns }\end{array}$ & $\begin{array}{l}\text { Number of types } \\
\text { of cereal crops } \\
\text { the household } \\
\text { grew in the past } \\
\text { year }\end{array}$ & $\begin{array}{l}\text { Number of types } \\
\text { of non-cereal } \\
\text { crops the } \\
\text { household grew } \\
\text { in the past year }\end{array}$ \\
\hline $\begin{array}{l}\text { Intervention } \\
\text { group mean }\end{array}$ & 0.30 & 0.57 & 0.37 & 0.41 \\
\hline $\begin{array}{l}\text { Comparison } \\
\text { group mean }\end{array}$ & 0.22 & 0.33 & 0.24 & 0.24 \\
\hline \multirow[t]{2}{*}{ Difference: } & $0.09^{* *}$ & $0.24^{* *}$ & $0.13^{\star * *}$ & $0.18^{\star \star \star}$ \\
\hline & $(0.04)$ & $(0.10)$ & $(0.05)$ & $(0.07)$ \\
\hline $\begin{array}{l}\text { Observations } \\
\text { (intervention } \\
\text { group) }\end{array}$ & 280 & 280 & 280 & 280 \\
\hline $\begin{array}{l}\text { Observations } \\
\text { (total) }\end{array}$ & 807 & 807 & 807 & 807 \\
\hline
\end{tabular}

Standard errors in parentheses; * $p<0.1,{ }^{* *} p<0.05,{ }^{* * *} p<0.01$; PSM estimates are bootstrapped with 1,000 repetitions.

The project also appears to have effected a moderate increase on the number of types of crops households cultivated. These results persist both for cereal crops and non-cereal grows grown in the last year. While the number of types reported in Columns 3 and 4 appears small, recall that this is an average across the matched sample, and the proportion of households growing crops is relatively small. If we restrict the sample to only those crop-growing households, we see project households growing an average of 1.2 cereal crop types and 1.3 non-cereal crop types compared to 1.1 and 1.0 respectively among the non-project households. When the sample is restricted to these households, the differences are no longer statistically significant, which suggests that the project's main effect has been on the likelihood of growing crops, and not the number or diversity of crops cultivated.

In Table 6.10 we consider how the project affected women's responsibility for cultivating crops. We show whether or not women in the household were responsible for farming any crops, and if we take the sample as a whole, the results show that in 20 percent of project households women were mainly responsible for farming at least one type of crop. While there appears to be a small difference between project and comparison households in this regard (Column 1), when the sample is restricted to crop-growing households, there is no difference between project and 
comparison households, suggesting that there is not sufficient evidence that the project has affected this measure.

Table 6.10: Women's responsibility for crop cultivation

\begin{tabular}{|l|l|}
\hline & $\mathbf{1}$ \\
\hline & $\begin{array}{l}\text { Women in the household } \\
\text { were mainly responsible } \\
\text { for farming at least one } \\
\text { type of crop }\end{array}$ \\
\hline $\begin{array}{l}\text { Intervention } \\
\text { group mean }\end{array}$ & 0.20 \\
\hline $\begin{array}{l}\text { Comparison } \\
\text { group mean }\end{array}$ & 0.14 \\
\hline Difference: & $0.06^{*}$ \\
\hline $\begin{array}{l}\text { Observations } \\
\text { (intervention } \\
\text { group) }\end{array}$ & 280 \\
\hline $\begin{array}{l}\text { Observations } \\
\text { (total) }\end{array}$ & 807 \\
\hline
\end{tabular}

Standard errors in parentheses; ${ }^{*} p<0.1,{ }^{* *} p<0.05,{ }^{* * *} p<0.01$; PSM estimates are bootstrapped with 1,000 repetitions.

In Table 6.11, we investigate crop sales. For each type of crop grown in the previous year, respondents were asked what proportion, if any, they sold to market. We report whether households sold any crops that they grew, and the proportion of crop types they sold. The project appeared to have positive and statistically significantly effects on these measures. In the intervention group, 12 percent of households sold some crops, approximately triple the figure (4 percent) in the comparison group. Among the sub-sample of crop-growing households, again there was nearly a three-fold difference in the proportion of crop types sold, as shown in Column 2.

\section{Table 6.11: Crop sales}

\begin{tabular}{|l|l|l|}
\hline & $\mathbf{1}$ & $\mathbf{2}$ \\
\hline & $\begin{array}{l}\text { Household sold any crops } \\
\text { grown }\end{array}$ & $\begin{array}{l}\text { Proportion of types of } \\
\text { crops household sold }\end{array}$ \\
\hline $\begin{array}{l}\text { Intervention } \\
\text { group mean }\end{array}$ & 0.12 & 0.29 \\
\hline $\begin{array}{l}\text { Comparison } \\
\text { group mean }\end{array}$ & 0.04 & 0.11 \\
\hline Difference: & $0.08^{\star * *}$ & $0.20^{\star * *}$ \\
\hline $\begin{array}{l}\text { Observations } \\
\text { (intervention } \\
\text { group) }\end{array}$ & 280 & $(0.05)$ \\
\hline $\begin{array}{l}\text { Observations } \\
\text { (total) }\end{array}$ & 807 & 85 \\
\hline
\end{tabular}

Standard errors in parentheses; ${ }^{*} p<0.1,{ }^{* *} p<0.05,{ }^{* * *} p<0.01$; PSM estimates are bootstrapped with 1,000 repetitions.

We also wanted to compare whether there were any differences between project and comparison households in terms of the markets for crops, i.e. inside/outside the community, but the sample of households making sales is too small to draw any meaningful conclusions. 


\subsection{NON-FARM ACTIVITIES}

In this final section on livelihood strategies, we consider the project's impact on non-farm income-generating activities. As discussed in Section 2, this was a key avenue through which the project aimed to increase resilience.

Table 6.12: Non-farm livelihood activities - summary

\begin{tabular}{|l|l|l|l|}
\hline & $\mathbf{1}$ & $\mathbf{2}$ & $\mathbf{3}$ \\
\hline & $\begin{array}{l}\text { Household } \\
\text { engaged in any } \\
\text { non-farm income- } \\
\text { generating } \\
\text { activities in the } \\
\text { past 12 months }\end{array}$ & $\begin{array}{l}\text { Number of non- } \\
\text { farm income- } \\
\text { generating } \\
\text { activities that the } \\
\text { household } \\
\text { engaged in }\end{array}$ & $\begin{array}{l}\text { Female } \\
\text { household } \\
\text { member engaged } \\
\text { in any non-farm } \\
\text { income- } \\
\text { generating } \\
\text { activities }\end{array}$ \\
\hline $\begin{array}{l}\text { Intervention } \\
\text { group mean }\end{array}$ & 0.34 & 0.36 & 0.29 \\
\hline $\begin{array}{l}\text { Comparison } \\
\text { group mean }\end{array}$ & 0.26 & 0.28 & 0.21 \\
\hline Difference: & $0.08^{\star *}$ & $0.08^{* *}$ & $0.08^{\star *}$ \\
\hline$(0.04)$ & $(0.04)$ & $(0.03)$ \\
\hline $\begin{array}{l}\text { Observations } \\
\text { (intervention } \\
\text { group) }\end{array}$ & 280 & 280 & 280 \\
\hline $\begin{array}{l}\text { Observations } \\
\text { (total) }\end{array}$ & 807 & 807 & 807 \\
\hline
\end{tabular}

Standard errors in parentheses; ${ }^{*} p<0.1,{ }^{* *} p<0.05,{ }^{* * *} p<0.01$; PSM estimates are bootstrapped with 1,000 repetitions.

In Table 6.12, we begin (in Column 1) by showing the proportion of households engaging in non-farm activities in the intervention and comparison groups. The project appeared to have a small but statistically significant positive effect on whether a household engaged in incomegenerating activities in the previous 12 months, with 34 percent of project households reporting activity compared to 26 percent of non-project households. Similarly, while the average number of activities per household is small, there is some evidence that project households were engaged in a greater number of activities than non-project households. Finally (in Column 3), we see that the project appeared again to have a small but statistically positive effect on the proportion of households that had a female member engaged in non-farm income-generating activities

In Table 6.13 we disaggregate the results by considering whether households' likelihood of participating in each different off-farm occupation was affected by the project. We can see that the results in Column 2 show that project appeared to have a small but statistically significant positive effect on whether a household had its own business. This may be an effect of the household business training offered through the CDMCs. It is interesting to note, however, that there was no clear evidence that project households were more likely to have a more formal business plan (Column 6 ) for their household initiatives.

Table 6.13 also shows some interesting findings in terms of whether households engaged in harvesting and selling wild plants or wood (Column 4). The data suggests that project households are significantly less likely to be engaged in such activities. This may be an effect of the project's aim to encourage proper utilization of natural resources. Such a theory is strengthened by the results in Column 5 where we see the project appears to have led to a decrease in the proportion of project households burning plants to make charcoal. Of the nonproject households who reported engaging in harvesting/selling wild plants or wood, 91 percent said they burnt the plants to make charcoal, whereas 79 percent of project households reported the same. 
Table 6.13: Non-farm livelihood activities - detail

\begin{tabular}{|l|l|l|l|}
\hline & $\mathbf{1}$ & $\mathbf{2}$ & $\mathbf{3}$ \\
\hline & $\begin{array}{l}\text { Casual labour } \\
\text { (e.g. construction, } \\
\text { working short- } \\
\text { term in a factory) }\end{array}$ & $\begin{array}{l}\text { Household } \\
\text { business (e.g. } \\
\text { retail shop, hotel, } \\
\text { tea shop) }\end{array}$ & $\begin{array}{l}\text { Household } \\
\text { engaged in } \\
\text { providing a } \\
\text { service } \\
\text { (community } \\
\text { health worker, } \\
\text { mechanic, driver, } \\
\text { etc.) }\end{array}$ \\
\hline $\begin{array}{l}\text { Intervention } \\
\text { group mean }\end{array}$ & 0.15 & 0.32 & 0.08 \\
\hline $\begin{array}{l}\text { Comparison } \\
\text { group mean }\end{array}$ & 0.11 & 0.24 & 0.06 \\
\hline Difference: & 0.04 & $0.08^{* *}$ & 0.02 \\
\hline $\begin{array}{l}\text { Observations } \\
\text { (intervention } \\
\text { group) }\end{array}$ & 280 & $(0.03)$ & $(0.02)$ \\
\hline $\begin{array}{l}\text { Observations } \\
\text { (total) }\end{array}$ & 807 & 280 & 280 \\
\hline
\end{tabular}

\begin{tabular}{|l|l|l|l|}
\hline & $\mathbf{4}$ & $\mathbf{5}$ & $\mathbf{6}$ \\
\hline & $\begin{array}{l}\text { Household } \\
\text { engaged in } \\
\text { harvesting and } \\
\text { selling wild plants } \\
\text { or wood }\end{array}$ & $\begin{array}{l}\text { Household } \\
\text { burned plants to } \\
\text { make charcoal }\end{array}$ & $\begin{array}{l}\text { Household has a } \\
\text { business plan }\end{array}$ \\
\hline $\begin{array}{l}\text { Intervention } \\
\text { group mean }\end{array}$ & 0.40 & 0.79 & 0.18 \\
\hline $\begin{array}{l}\text { Comparison } \\
\text { group mean }\end{array}$ & 0.48 & 0.91 & 0.15 \\
\hline Difference: & $-0.08^{* *}$ & $-0.11^{* * *}$ & 0.05 \\
\hline $\begin{array}{l}\text { Observations } \\
\text { (intervention } \\
\text { group) }\end{array}$ & 280 & $(0.04)$ & $(0.05)$ \\
\hline $\begin{array}{l}\text { Observations } \\
\text { (total) }\end{array}$ & 807 & 112 & 90 \\
\hline
\end{tabular}

Standard errors in parentheses; * $p<0.1,{ }^{* *} p<0.05,{ }^{* * *} p<0.01$; PSM estimates are bootstrapped with 1,000 repetitions.

\subsection{SELF-ESTIMATED INCOME}

The questionnaire included a short section where respondents were asked to estimate their income for the past four weeks and the past 12 months. We also asked respondents to estimate what their approximate income might be in the four weeks and 12 months following the survey. We report on the findings below, but the results should be interpreted with great caution. Assessing household income in this way is not considered best practice - the usual approach is to ask households to report on their consumption of various goods and services over a particular period and then use the results as a proxy for understanding household income. Due to time restraints and other priorities for data collection in this survey we were unable to include consumption questions. We would suggest the wealth analysis in Section 6.8 is a more robust and reliable approach to assessing household material well-being.

Table 6.14 presents the log analysis of the income reported by respondents. The log analysis is more reliable as it reduces the effects of extreme outliers in the data, which are likely to be due 
to the data being estimates from the respondents. The data suggests there is no clear evidence that the project affected income in the four weeks or the 12 months prior to the survey. Similarly, Table 6.15 shows that there appears to be no difference between project and non-project households in their expectations of income in the four weeks or 12 months after the survey.

Table 6.14: Household income in the last 4 weeks/12 months

\begin{tabular}{|l|l|l|}
\hline & $\mathbf{1}$ & $\mathbf{2}$ \\
\hline & $\begin{array}{l}\text { Log of household } \\
\text { income in the last } \\
\text { 4 weeks }\end{array}$ & $\begin{array}{l}\text { Log of household } \\
\text { income in the last } \\
12 \text { months }\end{array}$ \\
\hline $\begin{array}{l}\text { Intervention } \\
\text { group mean }\end{array}$ & 7.53 & 9.60 \\
\hline $\begin{array}{l}\text { Comparison } \\
\text { group mean }\end{array}$ & 7.66 & 9.68 \\
\hline Difference: & -0.13 & -0.08 \\
\hline $\begin{array}{l}\text { Observations } \\
\text { (intervention } \\
\text { group) }\end{array}$ & 280 & $(0.14)$ \\
\hline $\begin{array}{l}\text { Observations } \\
\text { (total) }\end{array}$ & 807 & 280 \\
\hline
\end{tabular}

Standard errors in parentheses; * $p<0.1,{ }^{* *} p<0.05,{ }^{* * *} p<0.01$; PSM estimates are bootstrapped with 1,000 repetitions.

Table 6.15: Household income expected in the next 4 weeks/12 months

\begin{tabular}{|l|l|l|}
\hline & $\mathbf{1}$ & $\mathbf{2}$ \\
\hline & $\begin{array}{l}\text { Log of household } \\
\text { income expected } \\
\text { in the next 4 } \\
\text { weeks }\end{array}$ & $\begin{array}{l}\text { Log of household } \\
\text { income expected } \\
\text { in the next 12 } \\
\text { months }\end{array}$ \\
\hline $\begin{array}{l}\text { Intervention } \\
\text { group mean }\end{array}$ & 7.57 & 9.47 \\
\hline $\begin{array}{l}\text { Comparison } \\
\text { group mean }\end{array}$ & 7.64 & 9.48 \\
\hline \begin{tabular}{l} 
Difference: \\
\hline
\end{tabular} & -0.07 & -0.02 \\
\hline $\begin{array}{l}\text { Observations } \\
\text { (intervention } \\
\text { group) }\end{array}$ & 280 & $(0.17)$ \\
\hline $\begin{array}{l}\text { Observations } \\
\text { (total) }\end{array}$ & 807 & 280 \\
\hline
\end{tabular}

Standard errors in parentheses; * $p<0.1,{ }^{* *} p<0.05,{ }^{* * *} p<0.01$; PSM estimates are bootstrapped with 1,000 repetitions.

\subsection{RISK MANAGEMENT STRATEGIES}

In this section, we briefly report on the adoption of coping and risk-management strategies in the sample. Households were asked whether they had taken a list of actions to protect themselves, their crops, or their assets from disaster since 2012. The proportion of households reporting that they had undertaken each of these actions is shown in Table 6.16.

The overall picture emerging from the results in this table is that these risk-management strategies were undertaken more commonly among the project households than the non-project households in our sample. The only activity showing no significant difference between project and non-project households is the making and selling of products made from wild plants. But with the exception of this particular activity, the results suggest that the project has had a 
statistically significant effect on whether or not households implemented risk-management strategies.

Similarly, in Table 6.17 we report on a variety of actions that households made to prepare for drought in the 12 months prior to the survey. As in Table 6.16, the overall picture is that for six of the eight actions covered in the survey, project households were more likely to implement them than the non-project households in our sample.

Table 6.16: Risk-management activities since 2012

\begin{tabular}{|l|l|l|l|l|}
\hline & $\mathbf{1}$ & $\mathbf{2}$ & $\mathbf{3}$ & $\mathbf{4}$ \\
\hline & $\begin{array}{l}\text { Household started } \\
\text { to sell livestock in } \\
\text { a different market } \\
\text { to normal }\end{array}$ & $\begin{array}{l}\text { Household } \\
\text { migrated } \\
\text { livestock to a } \\
\text { different area } \\
\text { than before }\end{array}$ & $\begin{array}{l}\text { Household began } \\
\text { harvesting water } \\
\text { for the first time }\end{array}$ & $\begin{array}{l}\text { Household } \\
\text { conserved feed } \\
\text { for dry period for } \\
\text { the first time }\end{array}$ \\
\hline $\begin{array}{l}\text { Intervention } \\
\text { group mean }\end{array}$ & 0.22 & 0.17 & 0.13 & 0.13 \\
\hline $\begin{array}{l}\text { Comparison } \\
\text { group mean }\end{array}$ & 0.14 & 0.10 & 0.06 & 0.04 \\
\hline \begin{tabular}{l} 
Difference: \\
\hline
\end{tabular} & $0.08^{* *}$ & $0.06^{* *}$ & $0.07^{* * *}$ & $0.08^{* * *}$ \\
\hline $\begin{array}{l}\text { Observations } \\
\text { (intervention } \\
\text { group) }\end{array}$ & 280 & $(0.03)$ & $(0.02)$ & $(0.02)$ \\
\hline $\begin{array}{l}\text { Observations } \\
\text { (total) }\end{array}$ & 807 & 280 & 280 & 280 \\
\hline
\end{tabular}

\begin{tabular}{|l|l|l|l|l|}
\hline & $\mathbf{5}$ & $\mathbf{6}$ & $\mathbf{7}$ & $\mathbf{8}$ \\
\hline & $\begin{array}{l}\text { Household } \\
\text { cultivated a new } \\
\text { crop that it had } \\
\text { never cultivated } \\
\text { before }\end{array}$ & $\begin{array}{l}\text { Household used } \\
\text { medicines to } \\
\text { protect livestock } \\
\text { from disease }\end{array}$ & $\begin{array}{l}\text { Household } \\
\text { started harvesting } \\
\text { and selling wild } \\
\text { plants (such as } \\
\text { aloe vera or } \\
\text { prosopis), without } \\
\text { processing }\end{array}$ & $\begin{array}{l}\text { Household } \\
\text { started making } \\
\text { and selling } \\
\text { products made } \\
\text { from wild plants } \\
\text { (such mats or } \\
\text { brushes from } \\
\text { palm leaves) }\end{array}$ \\
\hline $\begin{array}{l}\text { Intervention } \\
\text { group mean }\end{array}$ & 0.17 & 0.28 & 0.29 & 0.02 \\
\hline $\begin{array}{l}\text { Comparison } \\
\text { group mean }\end{array}$ & 0.07 & 0.13 & 0.14 & 0.01 \\
\hline Difference: & $0.10^{\star \star *}$ & $0.15^{\star \star *}$ & $0.15^{\star \star \star}$ & 0.01 \\
\hline $\begin{array}{l}\text { Observations } \\
\text { (intervention } \\
\text { group) }\end{array}$ & 280 & $(0.03)$ & $(0.03)$ & $(0.01)$ \\
\hline $\begin{array}{l}\text { Observations } \\
\text { (total) }\end{array}$ & 807 & 280 & 280 & 280 \\
\hline
\end{tabular}




\begin{tabular}{|l|l|l|l|}
\hline & $\mathbf{9}$ & $\mathbf{1 0}$ & $\mathbf{1 1}$ \\
\hline & $\begin{array}{l}\text { Household } \\
\text { stockpiled wood or } \\
\text { wild plant products } \\
\text { to sell in bulk }\end{array}$ & $\begin{array}{l}\text { Household } \\
\text { engaged in } \\
\text { fishing or fish } \\
\text { processing }\end{array}$ & $\begin{array}{l}\text { Household used } \\
\text { mobile phone to } \\
\text { gain information } \\
\text { on the weather }\end{array}$ \\
\hline $\begin{array}{l}\text { Intervention } \\
\text { group mean }\end{array}$ & 0.19 & 0.04 & 0.03 \\
\hline $\begin{array}{l}\text { Comparison } \\
\text { group mean }\end{array}$ & 0.12 & 0.01 & 0.01 \\
\hline Difference: & $0.07^{* *}$ & $0.03^{* * *}$ & $0.03^{* *}$ \\
\hline$(0.03)$ & $(0.01)$ & $(0.01)$ \\
\hline $\begin{array}{l}\text { Observations } \\
\text { (intervention } \\
\text { group) }\end{array}$ & 280 & 280 & 280 \\
\hline $\begin{array}{l}\text { Observations } \\
\text { (total) }\end{array}$ & 807 & 807 & 807 \\
\hline
\end{tabular}

Standard errors in parentheses; ${ }^{*} \mathrm{p}<0.1,{ }^{* \star} \mathrm{p}<0.05,{ }^{* \star *} \mathrm{p}<0.01$; PSM estimates are bootstrapped with 1,000 repetitions.

Table 6.17: Responses to drought in the previous 12 months

\begin{tabular}{|c|c|c|c|c|}
\hline & 1 & 2 & 3 & 4 \\
\hline & $\begin{array}{l}\text { Sold some } \\
\text { livestock early }\end{array}$ & $\begin{array}{l}\text { Purchased } \\
\text { drought-resistant } \\
\text { animals }\end{array}$ & $\begin{array}{l}\text { Stockpiled extra } \\
\text { feed for animals }\end{array}$ & $\begin{array}{l}\text { Asked relatives } \\
\text { outside the } \\
\text { community for } \\
\text { help }\end{array}$ \\
\hline $\begin{array}{l}\text { Intervention } \\
\text { group mean }\end{array}$ & 0.29 & 0.15 & 0.20 & 0.45 \\
\hline $\begin{array}{l}\text { Comparison } \\
\text { group mean }\end{array}$ & 0.20 & 0.11 & 0.12 & 0.31 \\
\hline \multirow[t]{2}{*}{ Difference: } & $0.09^{* *}$ & 0.04 & $0.08^{\star * *}$ & $0.14^{\star * \star}$ \\
\hline & $(0.04)$ & $(0.03)$ & $(0.03)$ & $(0.04)$ \\
\hline $\begin{array}{l}\text { Observations } \\
\text { (intervention } \\
\text { group) }\end{array}$ & 280 & 280 & 280 & 280 \\
\hline $\begin{array}{l}\text { Observations } \\
\text { (total) }\end{array}$ & 807 & 807 & 807 & 807 \\
\hline
\end{tabular}

\begin{tabular}{|l|l|l|l|l|}
\hline & $\mathbf{5}$ & $\mathbf{6}$ & $\mathbf{7}$ & $\mathbf{8}$ \\
\hline & $\begin{array}{l}\text { Sent some } \\
\text { household } \\
\text { members to a town }\end{array}$ & $\begin{array}{l}\text { Grazed animals } \\
\text { on different plants } \\
\text { from normal }\end{array}$ & $\begin{array}{l}\text { Moved to areas } \\
\text { with better } \\
\text { pastures }\end{array}$ & $\begin{array}{l}\text { Moved to areas } \\
\text { around the lake } \\
\text { zone }\end{array}$ \\
\hline $\begin{array}{l}\text { Intervention } \\
\text { group mean }\end{array}$ & 0.29 & 0.26 & 0.50 & 0.15 \\
\hline $\begin{array}{l}\text { Comparison } \\
\text { group mean }\end{array}$ & 0.19 & 0.22 & 0.42 & 0.05 \\
\hline Difference: & $0.10^{\star * *}$ & 0.04 & $0.08^{\star *}$ & $0.10^{\star * *}$ \\
\hline$(0.04)$ & $(0.03)$ & $(0.04)$ & $(0.02)$ \\
\hline $\begin{array}{l}\text { Observations } \\
\text { (intervention } \\
\text { group) }\end{array}$ & 280 & 280 & 280 & 280 \\
\hline $\begin{array}{l}\text { Observations } \\
\text { (total) }\end{array}$ & 807 & 807 & 807 & 807 \\
\hline
\end{tabular}

Standard errors in parentheses; ${ }^{*} p<0.1,{ }^{* *} p<0.05,{ }^{* * *} p<0.01$; PSM estimates are bootstrapped with 1,000 repetitions.

We should, however, be somewhat cautious about interpreting the results in Table 6.16 and Table 6.17 in a completely positive light. In particular, it may be that these measures were 
necessary due to project households' continued exposure to risk. This is especially concerning if these sorts of investments come at the expense of investing in income-generating activities.

\subsection{WEALTH}

In this section, we explore the project's impact on households' wealth. Wealth may be interpreted in two ways from the perspective of resilience. Firstly, wealth may be seen as a driver of resilience, insofar as households can sell off assets in times of crisis, but also more easily finance the costly investments needed to adapt livelihood strategies and innovate. However, wealth may also be regarded as exactly the type of well-being indicator - a 'final' outcome - which would be improved in spite of shocks, stresses, and uncertainty in more resilient households. Typically, these types of final well-being outcomes take more time to change than more immediate drivers or characteristics of resilience.

During the course of the questionnaire, respondents were asked to provide information about their household's ownership of various assets (including livestock, productive equipment, and household goods), as well as about the conditions of the family's house, both in 2012 and at the time of the survey. This information on asset ownership and housing conditions was used to generate an index of overall household wealth.

The wealth index was generated under the assumption that, if each of the assets and housing characteristics constituted suitable indicators of household wealth, they should be correlated with each other. That is, a household that scores favourably on one particular wealth indicator should be more likely to do so for other wealth indicators. A small number of items that had low or negative correlations with the others were therefore not considered to be good wealth indicators and so were excluded from the index.

A data reduction technique called principal component analysis (PCA) was used to produce two indices of overall wealth, one based on the recalled data from 2012, and one based on the household's situation at the time of the survey. In particular, our wealth index is taken directly from the first principal component. ${ }^{12}$ PCA enables us to assign weights to the different assets, to capture as much information as possible from the data. Broadly, PCA assigns more weight to those assets that are less correlated with all the other assets, as these carry more information. By contrast, items with more intra-correlation are given less weight.

In order to ensure the same weights were applied to assets for both the recalled wealth index and the wealth index for the time of the survey, data from these two time periods were pooled before undertaking the PCA procedure. This means changes in wealth can be more easily compared over time. It should also be noted that the wealth index for 2012 is the measure that has been used throughout this analysis to control for baseline differences in wealth status between project and non-project households.

For the analysis in this section, we start by 'normalizing' the wealth index. ${ }^{13}$ This means that the impacts of the project that we report can be directly understood as the number of standard deviations by which the project improved wealth. This means the results from this Effectiveness Review can be more easily compared to other similar evaluations.

In Table 6.18, we estimate the project's impact on wealth in two ways. In Column 1 we report wealth for the project and non-project households at the time of the survey, using the regular matching procedure that has been used throughout the other tables in this report. In Column 2 , however, we take a slightly different approach. We calculate the differences between wealth at the time of the survey and in 2012, and compare these differences between project and nonproject households in the matched sample. For the results in Column 2, it is necessary to omit recalled wealth from the matching process. ${ }^{14}$ 
Table 6.18: Wealth

\begin{tabular}{|c|c|c|}
\hline & 1 & 2 \\
\hline & Normalized wealth index & $\begin{array}{l}\text { Difference in normalized } \\
\text { wealth index }\end{array}$ \\
\hline $\begin{array}{l}\text { Intervention group } \\
\text { mean }\end{array}$ & 0.14 & 0.43 \\
\hline $\begin{array}{l}\text { Comparison group } \\
\text { mean }\end{array}$ & 0.08 & 0.41 \\
\hline \multirow[t]{2}{*}{ Difference: } & 0.06 & 0.02 \\
\hline & $(0.08)$ & $(0.05)$ \\
\hline $\begin{array}{l}\text { Observations } \\
\text { (intervention group) }\end{array}$ & 280 & 280 \\
\hline Observations (total) & 807 & 799 \\
\hline
\end{tabular}

Standard errors in parentheses; * $p<0.1,{ }^{* *} p<0.05,{ }^{* * *} p<0.01$; PSM estimates are bootstrapped with 1,000 repetitions.

Although both the current wealth index and the difference in the wealth index were higher in the project households than the comparison households, these differences are not statistically significant. Therefore, our data do not provide evidence that the project had a positive impact on household wealth. It should, however, be remembered that changes in wealth status may require a longer time horizon in this context. As such, it may be useful to follow up this evaluation with future efforts to measure wealth status after a number of years.

\subsection{INDICATORS OF RESILIENCE}

In Section 5 we outlined our approach for measuring resilience in this Effectiveness Review. We described how to construct an overall index for resilience, with two potential strategies for weighting indicators against one another. As a reminder, the base resilience index is the proportion of characteristics in which the household scored positively (Column 1). Column 2 shows a second index, which is based on the idea of giving equal weight to each of the three resilience capacities. To do this we first created a separate index for each capacity by counting the proportion of indicators under that capacity in which the household scored positively. Then we took the average across these capacity-specific indices to give an overall resilience index. We refer to this as the equal capacities resilience index. We also created one additional measure whereby we tried to remove the more 'output-style' indicators, or 'low-hanging fruit' from the index, so that we could focus on whether there had been changes in the more outcome-level resilience characteristics. Column 3, therefore, shows the proportion of households scoring positively among a smaller number of outcome-level characteristics. The project's impact on resilience, measured in this way, is shown in Table 6.19 
Table 6.19: Indices of resilience

\begin{tabular}{|c|c|c|c|}
\hline & 1 & 2 & 3 \\
\hline & $\begin{array}{l}\text { Base resilience } \\
\text { index }\end{array}$ & $\begin{array}{l}\text { Equal capacities } \\
\text { resilience index }\end{array}$ & $\begin{array}{l}\text { Resilience index } \\
\text { with output } \\
\text { indicators } \\
\text { removed }\end{array}$ \\
\hline $\begin{array}{l}\text { Intervention } \\
\text { group mean }\end{array}$ & 0.44 & 0.43 & 0.42 \\
\hline $\begin{array}{l}\text { Comparison } \\
\text { group mean }\end{array}$ & 0.38 & 0.38 & 0.37 \\
\hline \multirow[t]{2}{*}{ Difference: } & $0.05^{\star * *}$ & $0.05^{\star * *}$ & $0.05^{\star * *}$ \\
\hline & $(0.01)$ & $(0.01)$ & $(0.01)$ \\
\hline $\begin{array}{l}\text { Observations } \\
\text { (intervention } \\
\text { group) }\end{array}$ & 280 & 280 & 280 \\
\hline $\begin{array}{l}\text { Observations } \\
\text { (total) }\end{array}$ & 807 & 807 & 807 \\
\hline
\end{tabular}

Standard errors in parentheses; * $p<0.1,{ }^{* *} p<0.05,{ }^{* * *} p<0.01$; PSM estimates are bootstrapped with 1,000 repetitions.

Overall, there is some evidence that the project increased households' resilience. Using all three weighting approaches, the resilience index was 5 percentage points higher in the intervention group compared with the comparison group. Focusing just on the base resilience index in Column 1, these results imply that project households scored positively, on average, in 44 percent of the resilience indicators, compared to 38 percent for the comparison households. Even with the more 'output-level' indicators removed from the index, the positive difference between the project and non-project households remains. All three of the differences - while small - were statistically significant, even at the 1 percent level.

To understand better what is driving these increases in the resilience index, it is important to compare project and comparison households in terms of all the constituent indicators. To gain an initial overview, Figure 6.1 presents the average proportions of intervention and comparison group households scoring positively on each of the resilience indicators. We then describe the results under each capacity of resilience in the sub-sections that follow. 
Figure 6.1: Results for characteristics of resilience

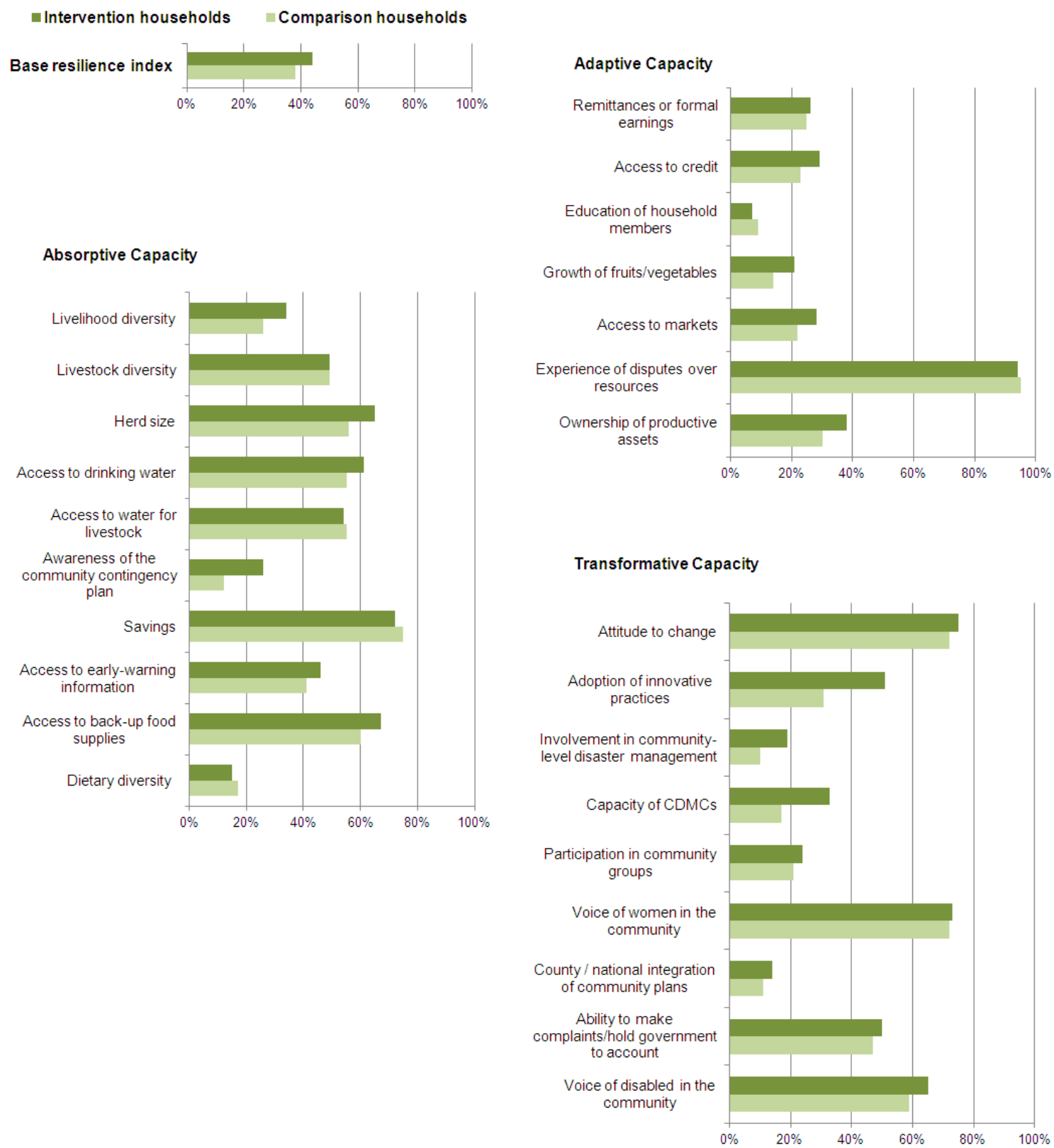

\subsubsection{Absorptive capacity}

Ten indicators of resilience falling under the 'absorptive' capacity were examined in this Effectiveness Review. The project's impact on these characteristics is shown in Table 6.20. Since the construction of each indicator is explained in Appendix 1, we focus here on the standout results. 
Table 6.20: Indicators of absorptive capacity

\begin{tabular}{|l|l|l|l|l|l|}
\hline & $\mathbf{1}$ & $\mathbf{2}$ & $\mathbf{3}$ & $\mathbf{4}$ & $\mathbf{5}$ \\
\hline & $\begin{array}{l}\text { Livelihood } \\
\text { diversity }\end{array}$ & $\begin{array}{l}\text { Livestock } \\
\text { diversity }\end{array}$ & Herd size & $\begin{array}{l}\text { Access to } \\
\text { drinking water }\end{array}$ & $\begin{array}{l}\text { Access to } \\
\text { water for } \\
\text { livestock }\end{array}$ \\
\hline $\begin{array}{l}\text { Intervention } \\
\text { group mean }\end{array}$ & 0.34 & 0.49 & 0.65 & 0.61 & 0.54 \\
\hline $\begin{array}{l}\text { Comparison } \\
\text { group mean }\end{array}$ & 0.26 & 0.49 & 0.56 & 0.55 & 0.55 \\
\hline Difference: & $0.08^{* *}$ & 0.00 & $0.09^{* *}$ & 0.06 & -0.01 \\
\hline $\begin{array}{l}\text { Observations } \\
\text { (intervention } \\
\text { group) }\end{array}$ & 280 & $(0.04)$ & $(0.04)$ & $(0.04)$ & $(0.04)$ \\
\hline $\begin{array}{l}\text { Observations } \\
\text { (total) }\end{array}$ & 807 & 280 & 280 & 280 & 280 \\
\hline
\end{tabular}

\begin{tabular}{|c|c|c|c|c|c|}
\hline & 6 & 7 & 8 & 9 & 10 \\
\hline & $\begin{array}{l}\text { Awareness of } \\
\text { the } \\
\text { community } \\
\text { contingency } \\
\text { plan }\end{array}$ & $\begin{array}{l}\text { Access to } \\
\text { savings }\end{array}$ & $\begin{array}{l}\text { Access to } \\
\text { early-warning } \\
\text { information }\end{array}$ & $\begin{array}{l}\text { Access to } \\
\text { back-up food } \\
\text { supplies }\end{array}$ & $\begin{array}{l}\text { Dietary } \\
\text { diversity }\end{array}$ \\
\hline $\begin{array}{l}\text { Intervention } \\
\text { group mean }\end{array}$ & 0.26 & 0.72 & 0.46 & 0.67 & 0.15 \\
\hline $\begin{array}{l}\text { Comparison } \\
\text { group mean }\end{array}$ & 0.12 & 0.75 & 0.41 & 0.60 & 0.17 \\
\hline \multirow[t]{2}{*}{ Difference: } & $0.15^{\star \star \star}$ & -0.02 & 0.06 & $0.07^{*}$ & -0.02 \\
\hline & $(0.03)$ & $(0.04)$ & $(0.04)$ & $(0.04)$ & $(0.03)$ \\
\hline $\begin{array}{l}\text { Observations } \\
\text { (intervention } \\
\text { group) }\end{array}$ & 280 & 280 & 280 & 280 & 280 \\
\hline $\begin{array}{l}\text { Observations } \\
\text { (total) }\end{array}$ & 807 & 807 & 807 & 807 & 807 \\
\hline
\end{tabular}

Standard errors in parentheses; * $p<0.1,{ }^{* *} p<0.05,{ }^{* * *} p<0.01$; PSM estimates are bootstrapped with 1,000 repetitions.

Several of the results in Table 6.20 echo findings that have been previously discussed in this report. For example, we see that the project households were more resilient in terms of livelihood diversity and herd size.

There are two further positive results in Table 6.20 that have not been highlighted already in the report. Firstly, as we see in Column 6, project households have greater awareness of the community disaster-management or contingency plan. On this measure, households scored positively if they knew that the community has such a plan and they were at least partly aware of its contents. Approximately 26 percent of project households met this condition compared to 12 percent of the comparison households.

There is also some modest evidence - though the difference is only statistically significant at the 10 percent level - that the project has improved the availability of back-up food supplies among project households. This perhaps should be expected considering the results in Table 6.3 earlier in the report showed that the provision of back-up food supplies was higher among project communities than comparison communities.

Table 6.20 also contains some equivocal results, where it was not possible to identify clear differences between the intervention and comparison groups with our data. For example, in terms of herd size (Column 3), access to water for drinking and livestock (Columns 4 and 5), 
access to early-warning information (Column 8) and dietary diversity (Column 10), we cannot say with any confidence whether the project had either a positive or a negative impact.

\subsubsection{Adaptive capacity}

We identified seven characteristics that were thought to capture 'adaptive' capacity in this Effectiveness Review. We report these results in Table 6.21, once again concentrating on the main results in the following text and reserving the full explanation of each indicator for Appendix 1.

Table 6.21: Indicators of adaptive capacity

\begin{tabular}{|l|l|l|l|l|}
\hline & $\mathbf{1}$ & $\mathbf{2}$ & $\mathbf{3}$ & $\mathbf{4}$ \\
\hline & $\begin{array}{l}\text { Remittances or } \\
\text { formal earnings }\end{array}$ & Access to credit & $\begin{array}{l}\text { Education of } \\
\text { household } \\
\text { members }\end{array}$ & $\begin{array}{l}\text { Growth of } \\
\text { fruits/vegetables }\end{array}$ \\
\hline $\begin{array}{l}\text { Intervention } \\
\text { group mean }\end{array}$ & 0.26 & 0.29 & 0.07 & 0.21 \\
\hline $\begin{array}{l}\text { Comparison } \\
\text { group mean }\end{array}$ & 0.25 & 0.23 & 0.09 & 0.14 \\
\hline Difference: & 0.01 & $0.07^{\star *}$ & -0.02 & $0.07^{\star *}$ \\
\hline $\begin{array}{l}\text { Observations } \\
\text { (intervention } \\
\text { group) }\end{array}$ & 280 & $(0.03)$ & $(0.02)$ & $(0.03)$ \\
\hline $\begin{array}{l}\text { Observations } \\
\text { (total) }\end{array}$ & 807 & 280 & 280 & 280 \\
\hline
\end{tabular}

\begin{tabular}{|l|l|l|l|}
\hline & $\mathbf{5}$ & $\mathbf{6}$ & $\mathbf{7}$ \\
\hline & $\begin{array}{l}\text { Access to } \\
\text { markets }\end{array}$ & $\begin{array}{l}\text { Experience of } \\
\text { disputes over } \\
\text { resources }\end{array}$ & $\begin{array}{l}\text { Ownership of } \\
\text { productive } \\
\text { assets }\end{array}$ \\
\hline $\begin{array}{l}\text { Intervention } \\
\text { group mean }\end{array}$ & 0.28 & 0.94 & 0.38 \\
\hline $\begin{array}{l}\text { Comparison } \\
\text { group mean }\end{array}$ & 0.22 & 0.95 & 0.30 \\
\hline Difference: & 0.05 & -0.01 & $0.08^{* *}$ \\
\hline $\begin{array}{l}\text { Observations } \\
\text { (intervention } \\
\text { group) }\end{array}$ & 280 & $(0.02)$ & $(0.04)$ \\
\hline $\begin{array}{l}\text { Observations } \\
\text { (total) }\end{array}$ & 807 & 280 & 280 \\
\hline
\end{tabular}

Standard errors in parentheses; * $p<0.1,{ }^{* *} p<0.05,{ }^{* * *} p<0.01$; PSM estimates are bootstrapped with 1,000 repetitions.

There is some evidence that project households had better access to credit than their nonproject comparators. Households were scored positively in terms of access to credit if they would be able to borrow 5,000 Kenyan shillings to invest in a business opportunity from someone other than friends, family or a local moneylender. Approximately 29 percent of project households reported that they had this level of access to credit, compared to 23 percent of nonproject households. Also, there is some evidence that the project has led to an increase in the proportion of households growing fruit or vegetables in the previous 12 months. Similarly, there are differences - at the 5 percent statistical significance level - that project households own more productive assets than comparison households.

By contrast, the remaining results in Table 6.21 do not show positive evidence in favour of the project. There were no statistically significant differences in terms of remittances or formal

Resilience in Kenya: Impact evaluation of Building Resilience in the Arid and Semi-Arid Lands of Northern Kenya. Effectiveness review series 2016-17 
earnings (Column 1), access to markets (Column 5) and experience of disputes over resources (Column 6). The education level of adult members in the household was also included as a characteristic of resilience, although it was likely to be too early in the course of the project to see any significant change. This was indeed the case, and Column 3 shows no significant differences between project and comparison households. It should be noted that there was an adult who had completed secondary education in 7 percent of project and 9 percent of nonproject households.

\subsubsection{Transformative capacity}

We used nine indicators to measure 'transformative' capacity in this Effectiveness Review. These results are presented in Table 6.22.

Table 6.22: Indicators of access transformative capacity

\begin{tabular}{|l|l|l|l|l|l|}
\hline & $\mathbf{1}$ & $\mathbf{2}$ & $\mathbf{3}$ & $\mathbf{4}$ & $\mathbf{5}$ \\
\hline & $\begin{array}{l}\text { Attitude to } \\
\text { change }\end{array}$ & $\begin{array}{l}\text { Adoption of } \\
\text { innovative } \\
\text { practices }\end{array}$ & $\begin{array}{l}\text { Involvement in } \\
\text { community- } \\
\text { level disaster } \\
\text { management }\end{array}$ & $\begin{array}{l}\text { Capacity of } \\
\text { CDMCs }\end{array}$ & $\begin{array}{l}\text { Participation } \\
\text { in community } \\
\text { groups }\end{array}$ \\
\hline $\begin{array}{l}\text { Intervention } \\
\text { group mean }\end{array}$ & 0.75 & 0.51 & 0.19 & 0.33 & 0.24 \\
\hline $\begin{array}{l}\text { Comparison } \\
\text { group mean }\end{array}$ & 0.72 & 0.31 & 0.10 & 0.17 & 0.21 \\
\hline Difference: & 0.03 & $0.21^{\star \star \star}$ & $0.09^{\star \star \star}$ & $0.16^{\star \star *}$ & 0.03 \\
\hline $\begin{array}{l}\text { Observations } \\
\text { (intervention } \\
\text { group) }\end{array}$ & 280 & $(0.04)$ & $(0.03)$ & $(0.04)$ & $(0.04)$ \\
\hline $\begin{array}{l}\text { Observations } \\
\text { (total) }\end{array}$ & 807 & 280 & 280 & 280 & 280 \\
\hline
\end{tabular}

\begin{tabular}{|l|l|l|l|l|}
\hline & $\mathbf{6}$ & $\mathbf{7}$ & $\mathbf{8}$ & $\mathbf{9}$ \\
\hline & $\begin{array}{l}\text { Voice of } \\
\text { women in the } \\
\text { community }\end{array}$ & $\begin{array}{l}\text { County/nation } \\
\text { al integration } \\
\text { of community } \\
\text { plans }\end{array}$ & $\begin{array}{l}\text { Ability to } \\
\text { make } \\
\text { complaints/hol } \\
\text { d government } \\
\text { to account }\end{array}$ & $\begin{array}{l}\text { Voice of } \\
\text { disabled in the } \\
\text { community }\end{array}$ \\
\hline $\begin{array}{l}\text { Intervention } \\
\text { group mean }\end{array}$ & 0.73 & 0.14 & 0.50 & 0.65 \\
\hline $\begin{array}{l}\text { Comparison } \\
\text { group mean }\end{array}$ & 0.72 & 0.11 & 0.47 & 0.59 \\
\hline Difference: & 0.02 & 0.03 & 0.03 & $0.07^{*}$ \\
\hline $\begin{array}{l}\text { Observations } \\
\text { intervention } \\
\text { group) }\end{array}$ & 280 & $(0.03)$ & $(0.04)$ & $(0.04)$ \\
\hline $\begin{array}{l}\text { Observations } \\
\text { (total) }\end{array}$ & 807 & 280 & 280 & 280 \\
\hline
\end{tabular}

Standard errors in parentheses; * $p<0.1,{ }^{* \star} p<0.05,{ }^{* * *} p<0.01$; PSM estimates are bootstrapped with 1,000 repetitions.

Several of these indicators are directly related to the project logic, so some of the positive results we see in Table 6.22 are unsurprising. For example, we know the project worked directly to improve the capacity of disaster-management committees (Columns 3 and 4), and encourage the implementation of more innovative practices (Column 2), and indeed the results show positive differences in favour of the project households in each of these measures. There is also 
some modest evidence that the project appears to have had an effect in increasing the voice of disabled people in the project communities.

The other results in Table 6.22 present no significant differences between project and comparison households. In some measures, this is perhaps surprising considering some of the objectives of the project, including the integration of community plans in higher levels of administrative planning (Column 7 ) and the ability of community members to make complaints or hold government to account (Column 8).

The differences between Columns 1 and 2 make interesting reading as a positive attitude to change or trying new activities is high in both project and comparison households, and it appears that the project has delivered in providing opportunities and then seeing take-up on the back of these positive attitudes.

Finally, we note that there are no statistically significant differences between the project and non-project household in terms of membership of community groups (Column 5) and the voice of women in the community (Column 6).

It should be noted that attitudes to the voice of women in the community was measured through an opinion question, which asked respondents to choose between two opposing statements. Respondents were asked whether they agreed more with (1) 'The needs of women are well represented to community-level decision makers, such as CDMCs' or (2) 'Community-level decision makers, such as CDMCs, mainly take into account the needs of men'. Those households agreeing with option 1 scored positively in terms of the voice of women in their communities. However, given that self-perception measures of this type may be susceptible to certain biases, we should be cautious about emphasizing this result too much.

\subsubsection{Comparing across capacities}

To provide an overall picture of the project's impact across the three capacities of resilience considered for this Effectiveness Review, we present the evidence for each capacity-specific index. These indices are created by averaging across all the indicators for each capacity. The results, using the matched sample, are shown in Figure 6.2.

\section{Figure 6.2: Capacity-specific resilience indices}
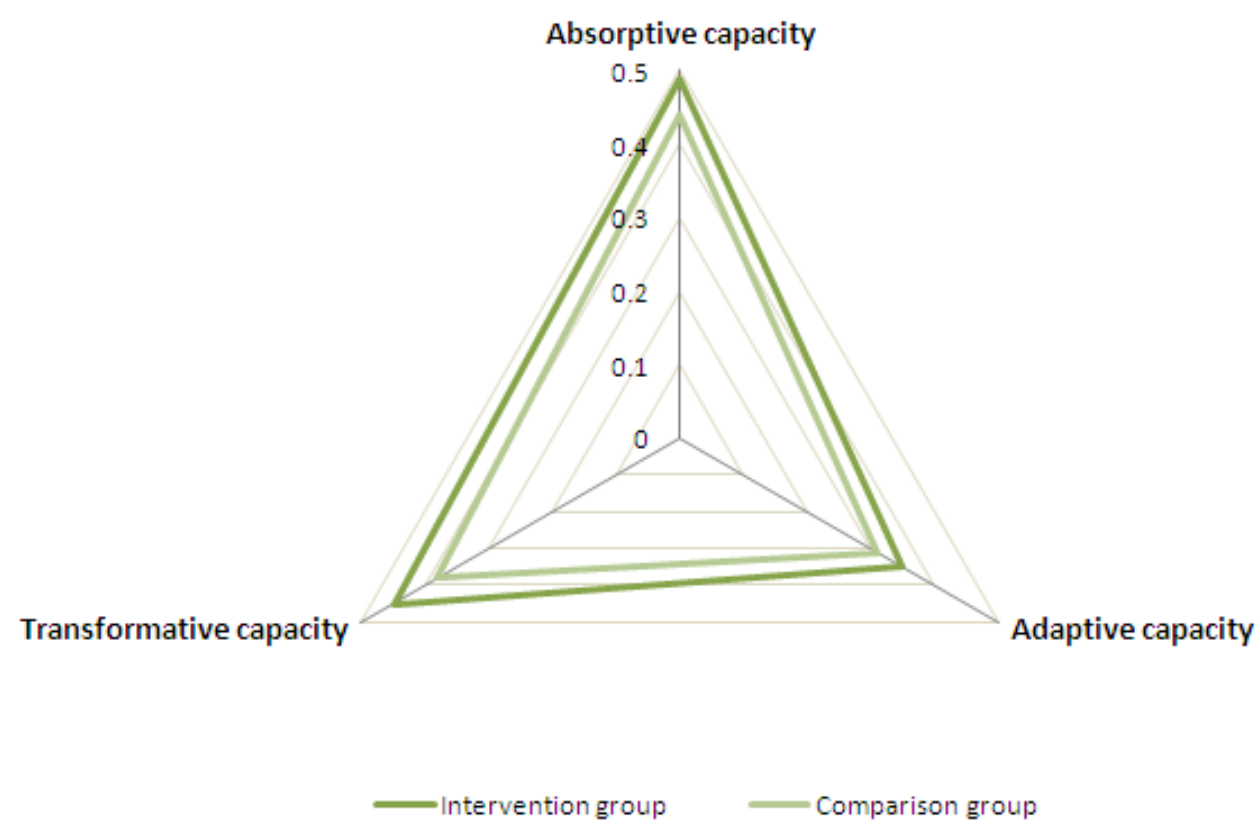

The most profound impacts of the project have occurred for the 'transformative' and 'absorptive' capacities. There was also a modest improvement in terms of the 'adaptive capacity.

Resilience in Kenya: Impact evaluation of Building Resilience in the Arid and Semi-Arid Lands of Northern Kenya. Effectiveness review series 2016-17 


\section{CONCLUSIONS}

\subsection{CONCLUSIONS}

We use this section to summarize the main findings from Section 6 .

The results clearly show that the project households in our survey participated more in the trainings and groups implemented by the project than comparison households. We can be especially confident that the project increased participation in Community Disaster Management Committees (CDMC) because we controlled for baseline group participation using recalled data in our analysis. Households in the project communities were much more likely to have received training, particularly in drought preparedness, livestock health and management of pasture lands, but also in issues relating to gender, advocacy and how to better claim goods and services from government and other providers. However, when we assess the implementation of particular activities that were believed to be connected to the project proposals put forward by the CDMCs, there was no evidence - with the exception of the provision of back-up food - of greater implementation in project communities. This could be due to government or other NGO initiatives in the study communities.

Our data suggest that the project had some positive effect on the probability of livestock ownership, but no strong evidence that the number of animals owned by project households has increased, or any decrease in the number of animals lost to disease, theft, drought or flood. Barriers to market are clearly still an issue, with three-quarters of those project households trying to sell in the previous 12 months reporting that distance to market was a serious constraint - a proportion not significantly different from households in comparison communities.

There is some evidence that the project affected households' decisions whether to engage in farming. Project households were also more likely to sell their agricultural produce. There were also positive and significant effects about the amount of land that households farmed and the number of crops in their portfolio, but there was no clear effect on increased involvement of women in crop cultivation.

There is evidence that the project has also effected an increase in households engaging in nonfarm income-generating activities. This is particularly driven by an increase in the proportion of households having their own household business, such as a retail outlet, café or accommodation. Interestingly, there is evidence that project households are significantly less likely to be engaged in the harvesting of plants or wood to make charcoal. This is likely to be due to the project's aim of encouraging proper utilization of natural resources.

Some of the largest differences identified between project and comparison households related to the greater take-up of risk-management strategies by households in the project communities. We should, however, be somewhat cautious about interpreting the results in a completely positive light. It may be that these measures were necessary due to project households' continued exposure to risk. This is especially concerning if these sorts of investments come at the expense of investing in income-generating activities.

We included a measure of wealth in our analysis to test whether there were any differences in terms of final outcomes between project and comparison households in our sample - that is, whether project households had been able to improve their well-being despite shocks, stresses and uncertainty. There were, however, no clear effects of the project in terms of household wealth. In part, this may be because the survey work was carried out when households in the project areas faced only limited drought and some localized flooding. It is difficult to examine households' resilience using final well-being indicators when they are not currently affected, or 
have not recently been affected, by shocks and stresses. Also, it may take a long time for projects of this type to influence outcomes like wealth.

The main outcome, on which this Effectiveness Review focused, was resilience. We created a list of indicators based on discussions with project staff and focus group discussions with local communities, which could plausibly have influenced households' ability to deal with shocks, stresses and uncertainty in the future. These were structured under the three capacities developed for Oxfam GB's approach for measuring resilience. The indicators were also aggregated to produce a set of overall resilience indexes. We experimented with different strategies for weighting the indicators and capacities to best reflect resilience in the local context.

Regardless of the weighting method used, the project had positive effects on the resilience index. The base resilience index was a little over 5 percent higher in the project households than the non-project households in the sample. The largest impacts of the project were in the 'absorptive' and 'transformative' capacities, highlighting - particularly in the latter capacity - the project's efforts in establishing the CDMCs and encouraging household adoption of new drought/risk mitigation practices. In the 'absorptive' capacity, the positive impact was driven largely by evidence of greater livelihood diversity among project households, as well as greater awareness of community disaster-management plans. In the 'adaptive' capacity, there was evidence of greater access to credit among project households, as well as evidence of greater crop cultivation. However, we could not find evidence for any improvement in access to livestock markets or changes in educational attainment among household members.

\subsection{PROGRAMME LEARNING CONSIDERATIONS}

\section{Take a more holistic approach to evaluation design, including discussions around suitable indicators and the possible establishment of a comparison group at the start of future projects.}

The quasi-experimental methodology deployed in this Effectiveness Review was successful due to the extensive inputs of project and partner staff during the fieldwork. The discussions around suitable comparison communities and the selection of good indicators of resilience were particularly rigorous and inclusive. However, it would have been better to have these discussions before the project activities began. As a minimum, this would have helped create a more comprehensive Monitoring, Evaluation, and Learning plan with a wide range of resilience indicators. Going further, it would also have been possible to implement a more robust evaluation design if the comparison group had been established before the project started and baseline data had been collected in project and non-project communities. To support this process in the future, the impact evaluation team should provide tools and resources to help project and programme staff with quasi-experimental evaluation designs, especially on the subject of setting up a comparison group. In addition, advice should be provided on opportunities to take advantage of planned programme design - e.g. use of a phased implementation approach - to better utilize quasi-experimental evaluation methods. Therefore, this learning point applies not only for programme staff, but also those working on monitoring and evaluation. 


\section{Continue to work on efforts to improve access to livestock markets in and around the project communities.}

The results from the review indicate that there is a need to assess how best to strengthen the work on livestock, in what remains a dominant pastoralist economy. While there was some evidence to suggest an increased probability of project households owning livestock, there was no evidence of reduced losses of livestock or greater herd sizes generally. Of those households who reported trying to sell their livestock in the previous 12 months, more than three-quarters cited distance to market as being a serious barrier to making sales. It is clearly a cross-cutting issue, but the results here warrant further analysis of options to improve pastoralists' access to markets, as well as strengthen the well-being of their livestock.

\section{Encourage further household implementation of risk- management strategies.}

One of the clear successes of the initiative has been in the greater take-up of risk-management strategies by households in the project communities. While the difference in take-up between project and comparison households is striking, there is clearly room to encourage greater adoption of these strategies. It is also worth mentioning the small, but significant, difference achieved in the proportion of project households cultivating and then selling crops. While further on-the-ground sensitization may be out of the scope of the next stage of development, there may be an option for Oxfam to be a convener and influencer in advocating for district-level takeup by government agricultural extension workers.

Being an intermediate step in the project's theory of change, it would also be interesting to carry out a subsequent review to assess whether this further implementation of various coping strategies does indeed generate greater impact for 'higher-level' outcomes, such as food security, wealth status and resilience.

\section{Review the success or otherwise of the CDMC proposals and especially whether or not CDMC plans have been integrated into county-wide development plans.}

One of the major successes of the project has been in the implementation and support of the community disaster-management committees. There was evidence that communities supported by the project had greater engagement in community-level disaster planning and were more aware of the contents of any disaster-management plan. They also had greater confidence in the capacity of the CDMC to help the community in difficult times. But there are two areas that warrant further research - both of which were key aspects of the project, but did not feature in the focus of this Effectiveness Review. Firstly, it would be interesting to review a selection of the CDMC proposals for community-based initiatives - both in terms of the quality of the proposal and the success or otherwise of the subsequent intervention. Due to the nature of this review, such fine-grained and small-scale analysis was not possible, but we would recommend followup research into one of the key aspects of the project. In addition, it was made explicit from the outset that one of the objectives was that the local-level CDMC plans would be integrated into county-level disaster-management plans. Again, detailed analysis was outside the scope of this review, but there appears to be an opportunity to build on the apparent success of the local CDMCs to gain learning and leverage change at a higher administrative level, thereby potentially affecting greater change. 


\section{APPENDIX 1: THRESHOLDS FOR CHARACTERISTICS OF RESILIENCE}

\begin{tabular}{|c|c|c|c|}
\hline Capacity & Characteristic & Threshold: A household scores positively if... & $\begin{array}{l}\text { Directly connected to } \\
\text { project logic? }\end{array}$ \\
\hline \multirow{10}{*}{ Absorptive } & Livelihood diversity & Household engaged in any non-farm activity in the past 12 months. & Yes \\
\hline & Livestock diversity & Household has at least two types of livestock. & No \\
\hline & Herd size & $\begin{array}{l}\text { Household owns at least one large herd animals (cattle, camels, or donkeys) or at least } 10 \\
\text { small herd animals (sheep or goats). }\end{array}$ & No \\
\hline & Access to drinking water & $\begin{array}{l}\text { Household uses a modern source as the main source of drinking water (piped into dwelling, } \\
\text { piped into plot/yard, public tap, tubewell/borehole with pump, protected dugwell, protected } \\
\text { spring, rainwater collection, unprotected dugwell) AND they can reach a source of drinking } \\
\text { water on foot during the dry season in less than one hour. }\end{array}$ & No \\
\hline & Access to water for livestock & $\begin{array}{l}\text { Household can reach a source of water for livestock on foot during the dry season in less than } \\
\text { one hour. }\end{array}$ & No \\
\hline & $\begin{array}{l}\text { Awareness of the community contingency } \\
\text { plan }\end{array}$ & $\begin{array}{l}\text { Household knows that the community has a disaster-management plan or a contingency plan, } \\
\text { and they are at least partly aware of its contents. }\end{array}$ & Yes \\
\hline & Savings & Respondent reports that household has any money savings & Yes \\
\hline & Access to early-warning information & $\begin{array}{l}\text { Household has received early-warning information from at least one source, which was } \\
\text { 'Somewhat helpful' }\end{array}$ & Yes \\
\hline & Access to back-up food supplies & $\begin{array}{l}\text { Household always has sufficient access to wild plants to provide food for people during the dry } \\
\text { season OR they feel at least moderately confident that they will receive back-up food supplies } \\
\text { from two or more sources during the dry season, if they need them. }\end{array}$ & No \\
\hline & Dietary diversity & $\begin{array}{l}\text { Household typically consumed one or more meals per day during the last seven days AND in the } \\
\text { past seven days had consumed a carbohydrate source every day, a protein source on at least } \\
\text { three days, and some fruit or vegetables on at least one day. }\end{array}$ & Yes \\
\hline \multirow{7}{*}{ Adaptive } & Remittances or formal earnings & $\begin{array}{l}\text { Household had at least one member working in formal employment OR had received remittances } \\
\text { in the past } 12 \text { months. }\end{array}$ & No \\
\hline & Access to credit & $\begin{array}{l}\text { Household would be able to borrow } 500 \text { Kenyan shillings to invest in a business opportunity from } \\
\text { someone other than relatives, neighbours, or a money lender. }\end{array}$ & Yes \\
\hline & Education of household members & $\begin{array}{l}\text { Household contains at least one working age member }(18+) \text { who has completed secondary } \\
\text { education. }\end{array}$ & Yes \\
\hline & Growth of fruits/vegetables & $\begin{array}{l}\text { Household grew any fruit or vegetables (including cowpeas and other legumes) in the past } 12 \\
\text { months. }\end{array}$ & Yes \\
\hline & Access to markets & $\begin{array}{l}\text { Household did not experience any problems trying to sell livestock in the past } 12 \text { months AND } \\
\text { had managed to sell livestock OR crops to someone outside their community. }\end{array}$ & No \\
\hline & Experience of disputes over resources & $\begin{array}{l}\text { Household had not been involved in any disagreements with other households (whether within } \\
\text { or outside the community) over access to, or use of, land, water or fishing areas. }\end{array}$ & No \\
\hline & Ownership of productive assets & $\begin{array}{l}\text { Household owns three or more small assets OR two or more large assets OR two small } \\
\text { assets and one large asset. (Small assets: hoes, machetes, rakes, axes, files, nets or hooks. } \\
\text { Large assets: fishing boats, generators, motorcycle, cars or other motor vehicles.) }\end{array}$ & Yes \\
\hline Transformative & Attitude to change & $\begin{array}{l}\text { Respondent agrees more with Option } 2 \text { out of: } \\
\text { 1. 'It is important to keep as large a herd as possible.' } \\
\text { 2. 'Sometimes, it is better to sell livestock to invest in other livelihood activities.' }\end{array}$ & No \\
\hline
\end{tabular}

Resilience in Kenya: Impact evaluation of Building Resilience in the Arid and Semi-Arid Lands of Northern Kenya. Effectiveness review series 2016-17 
AND respondent agrees more with Option 1 out of:

1. 'We should not be afraid to try new and different livelihood activities - sometimes they are better than the traditional livelihood activities.'

2. 'It is best to continue doing what we already know and do well, rather than experimenting with new approaches.

Adoption of innovative practices
Involvement in community-level disaster
management

Household has adopted any innovations that were not directly related to the project activities (all innovations except cultivating a new crop; harvesting and selling wild plants; making and selling products made from wild plants).

The household reports that the community has a CDMC or other disaster planning committee AND that at least one household member was involved in choosing the committee members.

Capacity of CDMCs

The household reports that the community has a CDMC or other disaster-planning committee AND that this committee does not lack both the knowledge and the resources it needs to help the community in difficult times.

Participation in community groups Household members participate in two or more community groups. Respondent agrees more with Option 1 out of:

1. 'The needs of women are well represented to community-level decision makers such as

Voice of women in the community CDMCs.'

2. 'Community-level decision makers, such as CDMCs, mainly take into account the needs of men.'

County/national integration of community plans

Respondent reports that the community has a long-term development plan AND they know that it is built into county or national government plans OR respondent reports that the community has a disaster-management plan or a contingency plan AND they know that it is built into county or national government plans.

Household had made a complaint to an external actor OR they had participated in a forum or group to hold the government to account in the past 12 months OR the respondent agrees group to hold the governm
more with Option 2 out of:

Ability to make complaints/hold government to account

1. 'The county government does not listen to the people in my community.'

2. 'The people in my community can often make their voices heard to the county government.'

Voice of disabled in the community
Respondent agrees more with Option 2 out of:

1. 'The main decisions taken by the community normally ignore the needs of disabled and

2. 'Community decisions typically take the needs of disabled and elderly people in account.' 


\section{APPENDIX 2: BASELINE STATISTICS BEFORE MATCHING}

\section{Table A2.1: Descriptive statistics before matching}

\begin{tabular}{|c|c|c|c|c|}
\hline & $\begin{array}{l}\text { Intervention } \\
\text { mean }\end{array}$ & $\begin{array}{l}\text { Comparison } \\
\text { mean }\end{array}$ & Difference & Standard error \\
\hline $\begin{array}{l}\text { Household was in the lowest } \\
20 \% \text { of the wealth distribution, } \\
\text { in } 2012(\%)\end{array}$ & 0.232 & 0.183 & $0.049^{*}$ & 0.03 \\
\hline $\begin{array}{l}\text { Household was in the second } \\
20 \% \text { of the wealth distribution, } \\
\text { in } 2012(\%)\end{array}$ & 0.243 & 0.178 & $0.065^{* *}$ & 0.03 \\
\hline $\begin{array}{l}\text { Household was in the third } \\
20 \% \text { of the wealth distribution, } \\
\text { in } 2012(\%)\end{array}$ & 0.204 & 0.198 & 0.005 & 0.03 \\
\hline $\begin{array}{l}\text { Household was in the fourth } \\
20 \% \text { of the wealth distribution, } \\
\text { in } 2012(\%)\end{array}$ & 0.171 & 0.215 & -0.043 & 0.03 \\
\hline $\begin{array}{l}\text { Household head can read and } \\
\text { write a simple letter }(\%)\end{array}$ & 0.146 & 0.169 & -0.022 & 0.03 \\
\hline $\begin{array}{l}\text { Household grew any crops in } \\
2012(\%)\end{array}$ & 0.279 & 0.217 & $0.062^{* *}$ & 0.03 \\
\hline Household head is male (\%) & 0.579 & 0.589 & -0.010 & 0.04 \\
\hline $\begin{array}{l}\text { Household head completed } \\
\text { primary education (\%) }\end{array}$ & 0.068 & 0.102 & -0.034 & 0.02 \\
\hline $\begin{array}{l}\text { Household had any off-farm } \\
\text { businesses in } 2012(\%)\end{array}$ & 0.175 & 0.178 & -0.003 & 0.03 \\
\hline $\begin{array}{l}\text { Household had any livestock } \\
\text { in } 2012(\%)\end{array}$ & 0.757 & 0.654 & $0.103^{\star * *}$ & 0.03 \\
\hline $\begin{array}{l}\text { Household was a member in } \\
\text { any community groups in } 2012 \\
(\%)\end{array}$ & 0.346 & 0.244 & $0.102^{\star \star \star}$ & 0.03 \\
\hline $\begin{array}{l}\text { Household was engaged in } \\
\text { mining in } 2012(\%)\end{array}$ & 0.107 & 0.159 & $-0.052^{* *}$ & 0.03 \\
\hline $\begin{array}{l}\text { Household was engaged in } \\
\text { wood or wild plant harvesting } \\
\text { in } 2012(\%)\end{array}$ & 0.400 & 0.320 & $0.080^{* *}$ & 0.04 \\
\hline $\begin{array}{l}\text { Household was engaged in } \\
\text { casual labour in } 2012(\%)\end{array}$ & 0.096 & 0.126 & -0.029 & 0.02 \\
\hline $\begin{array}{l}\text { Household had its own } \\
\text { business in } 2012(\%)\end{array}$ & 0.164 & 0.165 & -0.001 & 0.03 \\
\hline $\begin{array}{l}\text { Household received } \\
\text { remittances in } 2012(\%)\end{array}$ & 0.336 & 0.204 & $0.132^{\star \star *}$ & 0.03 \\
\hline $\begin{array}{l}\text { Number of people in the } \\
\text { household }\end{array}$ & 5.864 & 5.894 & -0.030 & 0.16 \\
\hline $\begin{array}{l}\text { Number of sheep the } \\
\text { household owned in } 2012\end{array}$ & 11.432 & 7.120 & $4.312^{\star \star \star}$ & 1.21 \\
\hline $\begin{array}{l}\text { Number of goats the } \\
\text { household owned in } 2012\end{array}$ & 45.289 & 29.724 & $15.565^{\star \star *}$ & 5.11 \\
\hline $\begin{array}{l}\text { Number of poultry the } \\
\text { household owned in } 2012\end{array}$ & 1.639 & 1.307 & 0.332 & 0.36 \\
\hline $\begin{array}{l}\text { Number of acres the } \\
\text { household owned in } 2012\end{array}$ & 0.400 & 0.313 & 0.087 & 0.09 \\
\hline
\end{tabular}

The construction of the wealth index is described in Section 6

Variables dated 2012 are estimates, based on recall data

${ }^{*} p<0.1,{ }^{* *} p<0.05,{ }^{* * *} p<0.01$

Resilience in Kenya: Impact evaluation of Building Resilience in the Arid and Semi-Arid Lands of Northern Kenya. Effectiveness review series 2016-17 


\section{APPENDIX 3: METHODOLOGY USED FOR PROPENSITY-SCORE MATCHING}

The results presented in Section 6 of this report were estimated using propensity-score matching (PSM). PSM is a statistical technique that allows us to estimate the effect of an intervention by accounting for the covariates that predict receiving the intervention, or 'treatment'. The idea behind PSM is to match similar individuals in the treatment or intervention group to those in the control or comparison group, based on observed characteristics at baseline. After each participant is matched with a non-participant, the average treatment effect on the treated (those who benefited from the intervention) is equal to the difference in average outcomes of the intervention and the comparison groups after project completion. This appendix describes and tests the specific matching procedure employed in this Effectiveness Review. A practical guide on the different approaches to matching may be found in Caliendo and Kopeinig (2008).

\section{Estimating propensity scores}

Finding an exact match for treated individuals, based on various baseline characteristics, would be very hard to implement in practice. Rosenbaum and Rubin (1983) demonstrated that a 'propensity score' could summarize all this information in one single variable. The propensity score is defined as the conditional probability of receiving the intervention given background variables. Specifically, propensity scores are calculated using a statistical probability model (e.g. probit or logit) to estimate the probability of participating in the project, conditional on a set of characteristics.

Table A3.1 shows the variables used to estimate the propensity score. Here, we report the marginal effects at the mean, and the corresponding standard errors. Following Caliendo and Kopeinig (2008), only variables that influence the participation decision, but are not affected by participation in the project, were included in our matching model. In the table, the dependent variable corresponds to whether an individual received the intervention - it is equal to 1 if the household belongs to one of the communities that benefited from the project activities, and 0 otherwise. The coefficients in the table correspond to the marginal effects, i.e. the change in the probability of receiving the intervention if the independent variable is increased by one.

\section{Defining the region of common support}

After estimating the propensity scores, we need to verify that there is a potential match for the observations in the intervention group with those from the comparison group. This means checking that there is common support. The area of common support is the region where the propensity-score distributions of the intervention and comparison groups overlap. The common support assumption ensures that each 'treatment [intervention] observation has a comparison observation 'nearby' in the propensity-score distribution' (Heckman, LaLonde and Smith, 1999). Figure A3.1 shows the propensity-score density plots for both groups. We observe that, although the distributions of propensity scores are clearly different between the intervention and comparison groups in each case, there is a reasonably good area of overlap between the groups. However, in constructing the model for household-level outcomes, 11 observations from the comparison group were dropped because there was not a suitable match for them. 
Table A3.1: Estimating the propensity score

\begin{tabular}{|c|c|c|c|}
\hline & Marginal effect & Standard error & $p$-value \\
\hline $\begin{array}{l}\mathrm{HH} \text { was in the lowest } 20 \% \text { of the wealth } \\
\text { distribution, in } 2010\end{array}$ & $0.17^{* *}$ & 0.06 & 0.01 \\
\hline $\begin{array}{l}\mathrm{HH} \text { was in the second } 20 \% \text { of the wealth } \\
\text { distribution, in } 2010\end{array}$ & $0.21^{* *}$ & 0.06 & 0.00 \\
\hline $\begin{array}{l}\mathrm{HH} \text { was in the third } 20 \% \text { of the wealth } \\
\text { distribution, in } 2010\end{array}$ & $0.14^{*}$ & 0.06 & 0.03 \\
\hline $\begin{array}{l}\mathrm{HH} \text { was in the fourth } 20 \% \text { of the wealth } \\
\text { distribution, in } 2010\end{array}$ & 0.06 & 0.06 & 0.29 \\
\hline $\begin{array}{l}\text { Household head can read and write a } \\
\text { simple letter? }(1=\mathrm{Y}, 0=N)\end{array}$ & 0.08 & 0.07 & 0.24 \\
\hline $\begin{array}{l}\text { HH undertook farming of crops in } 2012 ? \\
(1=Y, 0=N)\end{array}$ & 0.04 & 0.05 & 0.44 \\
\hline Household head is male? $(1=\mathrm{Y}, 0=\mathrm{N})$ & -0.02 & 0.04 & 0.58 \\
\hline $\begin{array}{l}\text { Household head has primary education? } \\
(1=Y, 0=N)\end{array}$ & -0.11 & 0.07 & 0.13 \\
\hline $\begin{array}{l}\text { HH had any off-farm income at the start in } \\
2012 ?(1=Y, 0=N)\end{array}$ & 0.00 & 0.16 & 1.00 \\
\hline HH had any livestock in 2012 & 0.00 & 0.04 & 0.96 \\
\hline $\begin{array}{l}\text { HH participated in any community groups } \\
\text { in } 2012 ?(1=Y, 0=N)\end{array}$ & $0.12^{* *}$ & 0.04 & 0.00 \\
\hline $\begin{array}{l}\mathrm{HH} \text { participated in mining in } 2012 ?(1=\mathrm{Y} \text {, } \\
0=\mathrm{N})\end{array}$ & -0.05 & 0.05 & 0.35 \\
\hline $\begin{array}{l}\mathrm{HH} \text { participated in wood harvesting for } \\
\text { charcoal in } 2012 ?(1=\mathrm{Y}, 0=\mathrm{N})\end{array}$ & $0.08^{*}$ & 0.04 & 0.03 \\
\hline $\begin{array}{l}\text { HH participated in casual labour in } 2012 ? \\
(1=Y, 0=N)\end{array}$ & -0.06 & 0.05 & 0.24 \\
\hline $\begin{array}{l}\text { HH had a household business in } 2012 ? \\
(1=Y, 0=N)\end{array}$ & 0.00 & 0.16 & 0.98 \\
\hline $\begin{array}{l}\mathrm{HH} \text { received remittances in } 2012 ?(1=\mathrm{Y} \text {, } \\
0=\mathrm{N})\end{array}$ & $0.18^{* * *}$ & 0.04 & 0.00 \\
\hline Household size & -0.01 & 0.01 & 0.43 \\
\hline 1 sheep & $0.00^{*}$ & 0.00 & 0.04 \\
\hline 1 goats & 0.00 & 0.00 & 0.12 \\
\hline 1 poultry & 0.01 & 0.00 & 0.10 \\
\hline 1 acres & 0.00 & 0.02 & 0.91 \\
\hline
\end{tabular}

The construction of the wealth index is described in Section 6. Variables dated 2012 are estimates, based on recall data Dependent variable is binary, taking 1 for project participant households, and 0 otherwise

${ }^{*} \mathrm{p}<0.1,{ }^{* *} \mathrm{p}<0.05,{ }^{* * *} \mathrm{p}<0.01$

\section{Figure A3:1 Histogram of propensity scores in the intervention and comparison groups}

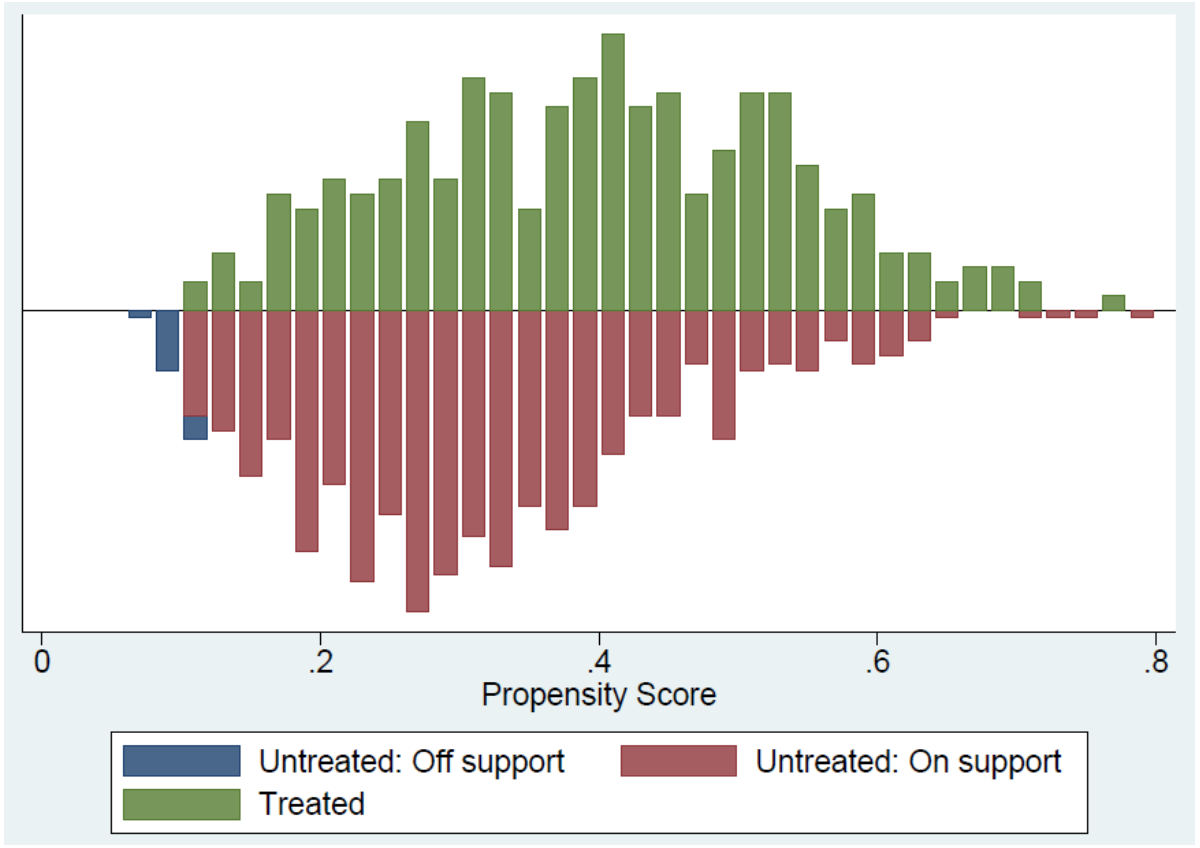

Resilience in Kenya: Impact evaluation of Building Resilience in the Arid and Semi-Arid Lands of Northern Kenya. Effectiveness review series 2016-17 


\section{Matching intervention households to comparison households}

Following Rosenbaum and Rubin (1983), households were matched based on their propensity scores. The literature has developed a variety of matching procedures. After a series of checks, we decided to employ the kernel matching algorithm for the results presented in this Effectiveness Review. Kernel matching assigns more weight to the closest comparison group observations that are found within a selected 'bandwidth'. Thus 'good' matches are given greater weight than 'poor' matches. We used the psmatch2 module in Stata with a bandwidth of 0.075 and restricted the analysis to the area of common support. When using PSM, standard errors of the estimates were bootstrapped using 1,000 repetitions, to account for the additional variation caused by the estimation of the propensity scores. ${ }^{15}$

\section{Checking balance}

For PSM to be valid, the intervention group and the matched comparison group need to be balanced. In other words, the intervention and comparison groups need to be similar in terms of their observed characteristics. The most straightforward method of doing this is to test whether there are any statistically significant differences in baseline covariates between the groups in the matched sample. The balance of each of the matching variables after kernel matching is shown in Table A3.2. There are no statistically significant differences between the intervention and comparison groups for any of the matching variables used in the matched sample. For all of these variables, the $p$-values for the difference in means tests are larger than 0.2. We can therefore conclude in each case that we have found a satisfactory match for the observable variable our sample.

Table A3.2: Balancing test on matching variables

\begin{tabular}{|c|c|c|c|}
\hline & $\begin{array}{l}\text { Intervention group } \\
\text { mean }\end{array}$ & $\begin{array}{l}\text { Comparison } \\
\text { group mean }\end{array}$ & $p$-value \\
\hline $\begin{array}{l}\mathrm{HH} \text { was in the lowest } 20 \% \text { of the wealth distribution, in } \\
2012\end{array}$ & 0.23 & 0.24 & 0.83 \\
\hline $\begin{array}{l}\mathrm{HH} \text { was in the second } 20 \% \text { of the wealth distribution, in } \\
2012\end{array}$ & 0.24 & 0.24 & 0.89 \\
\hline $\mathrm{HH}$ was in the third $20 \%$ of the wealth distribution, in 2012 & 0.20 & 0.20 & 0.89 \\
\hline $\begin{array}{l}\mathrm{HH} \text { was in the fourth } 20 \% \text { of the wealth distribution, in } \\
2012\end{array}$ & 0.17 & 0.18 & 0.83 \\
\hline $\begin{array}{l}\text { Household head can read and write a simple letter? }(1=\mathrm{Y} \text {, } \\
0=\mathrm{N})\end{array}$ & 0.15 & 0.16 & 0.71 \\
\hline $\mathrm{HH}$ undertook farming of crops in $2012 ?(1=\mathrm{Y}, 0=\mathrm{N})$ & 0.28 & 0.27 & 0.89 \\
\hline Household head is male? $(1=\mathrm{Y}, 0=\mathrm{N})$ & 0.58 & 0.60 & 0.63 \\
\hline Household head has primary education? $(1=\mathrm{Y}, 0=\mathrm{N})$ & 0.07 & 0.08 & 0.59 \\
\hline $\begin{array}{l}\mathrm{HH} \text { had any off-farm income at the start in } 2012 ?(1=\mathrm{Y}, \\
0=\mathrm{N})\end{array}$ & 0.18 & 0.18 & 0.93 \\
\hline $\mathrm{HH}$ had any livestock in 2012 & 0.76 & 0.76 & 0.98 \\
\hline $\begin{array}{l}\mathrm{HH} \text { participated in any community groups in } 2012 ?(1=\mathrm{Y} \text {, } \\
0=\mathrm{N})\end{array}$ & 0.35 & 0.35 & 0.90 \\
\hline $\mathrm{HH}$ participated in mining in $2012 ?(1=\mathrm{Y}, 0=\mathrm{N})$ & 0.11 & 0.10 & 0.88 \\
\hline $\begin{array}{l}\text { HH participated in wood harvesting for charcoal in } 2012 ? \\
(1=Y, 0=N)\end{array}$ & 0.49 & 0.39 & 0.88 \\
\hline $\mathrm{HH}$ participated in casual labour in $2012 ?(1=\mathrm{Y}, 0=\mathrm{N})$ & 0.10 & 0.19 & 0.84 \\
\hline HH had a household business in $2012 ?(1=\mathrm{Y}, 0=\mathrm{N})$ & 0.16 & 0.17 & 0.94 \\
\hline $\mathrm{HH}$ received remittances in $2012 ?(1=\mathrm{Y}, 0=\mathrm{N})$ & 0.34 & 0.34 & 0.95 \\
\hline Household size & 5.86 & 5.84 & 0.88 \\
\hline Number of sheep in 2012 & 11.43 & 11.29 & 0.93 \\
\hline Number of goats in 2012 & 45.29 & 43.36 & 0.78 \\
\hline Number of poultry in 2012 & 1.64 & 1.46 & 0.66 \\
\hline Number of acres in 2012 & 0.40 & 0.39 & 0.94 \\
\hline
\end{tabular}

The construction of the wealth index is described in Section 6. Variables dated 2012 are estimates, based on recall data ${ }^{*} p<0.1,{ }^{* *} p<0.05,{ }^{* * *} p<0.01$

Resilience in Kenya: Impact evaluation of Building Resilience in the Arid and Semi-Arid Lands of Northern Kenya. Effectiveness review series 2016-17 
In order to assess the robustness of the results presented in Section 6, a series of checks were carried out to determine whether the main findings of this report are sensitive to the estimation procedure - propensity-score matching with the kernel method - that was used to control for observable differences between the intervention and comparison group. This appendix presents five types of robustness checks.

\section{Multivariate regression}

The first robustness test we run is to estimate the impact of project participation using an ordinary least squares (OLS) regression. The main idea behind OLS is to isolate the variation in the outcome variable that is due to the intervention status - the project's impact - by controlling directly for the influence that observable differences between the intervention and comparison group have on outcomes. To do this, we estimate Equation $1 .{ }^{16}$

\section{Equation 1}

$$
Y_{i}=\alpha+\beta_{1} \tau_{i}+\boldsymbol{X}_{\boldsymbol{i}}^{\prime} \boldsymbol{\delta}+\varepsilon_{i}
$$

In Equation 1, $Y_{i}$ is the dependent variable (the outcome) and $\boldsymbol{X}_{\boldsymbol{i}}$ is a column vector of the same matching variables listed in tables A3.1 or A3.2. The intervention status is given by a dummy variable $\left(\tau_{i}\right)$, which takes the value 1 if the household participated in the project and 0 otherwise. The key difference between this OLS regression model and the propensity score matching procedure used in the main report is that the OLS regression estimates a direct parametric relationship between the covariates in $\boldsymbol{X}_{\boldsymbol{i}}$ and the dependent variable $Y_{i}$. This means it is possible to include the observations that were excluded due to being off common support in Section 6 by extrapolating the relationship between $\boldsymbol{X}_{\boldsymbol{i}}$ and $Y_{i}$. It should be borne in mind, however, that extrapolating in this way may bias the results if the covariates are distributed very differently between the intervention and comparison groups (Rubin, 2001). ${ }^{17}$

It is also important to note that, as with the PSM methods used in the main body of the report, OLS regressions can only account for observable differences between the intervention and comparison groups. Unobservable differences may still bias the results. In the tables that follow, only the estimate of $\beta_{1}$ will be reported.

\section{Multivariate regression with alternative matching variables}

Given the importance of controlling for recalled group participation for minimizing bias, we test whether our results are sensitive to the way this information is captured by the matching variables. To do this, we alter $\boldsymbol{X}_{\boldsymbol{i}}$, removing the dummy variable for whether the household participated in any community groups in 2010 and adding instead: (1) the number of community groups in which the household participated in 2010, and (2) a dummy variable for whether the household participated in a WEG. Once again, we only report the estimates of $\beta_{1}$.

\section{Propensity-score weighting}

Following the example of Hirano and Imbens (2001) we also estimate OLS regressions, using the same model as in Equation 1, but weighting the observations according to the propensity score. Observations are assigned weights equal to 1 for the intervention households and $\hat{P}\left(\boldsymbol{X}_{\boldsymbol{i}}\right) /\left(1-\hat{P}\left(\boldsymbol{X}_{\boldsymbol{i}}\right)\right)$ for the comparison households. The variable $\hat{P}\left(\boldsymbol{X}_{\boldsymbol{i}}\right)$ represents the probability of a household being in the intervention group, given their observable characteristics, measured 
through the vector of matching variables $X_{i}$ - this was estimated in the probit regressions in Appendix 3 . We report the estimates of $\beta_{1}$ in the same way as the regular OLS regressions.

\section{Nearest neighbour matching}

The nearest neighbour (NN) matching algorithm matches each observation from the intervention group with an observation from the comparison group that is closest in terms of their propensity score. ${ }^{18}$ In this robustness check, we apply the NN method 'with replacement', meaning that comparison observations can be matched to intervention observations more than once. ${ }^{19}$ In the tables below, we report the estimated differences between the intervention and comparison groups.

In the remainder of this appendix, we report these robustness checks for the main results of the report.

Table A4.1: Overall resilience indexes

\begin{tabular}{|l|l|l|l|}
\hline & $\mathbf{1}$ & $\mathbf{2}$ & $\mathbf{3}$ \\
\hline & Base resilience index & $\begin{array}{l}\text { Equal capacities } \\
\text { resilience index }\end{array}$ & $\begin{array}{l}\text { Resilience index with } \\
\text { output indicators } \\
\text { removed }\end{array}$ \\
\hline OLS regression & $0.06^{* *}$ & $0.06^{* * *}$ & $0.06^{* * *}$ \\
\hline$N$ & $(0.01)$ & $(0.01)$ & $(0.01)$ \\
\hline $\begin{array}{l}\text { OLS regression with } \\
\text { alternative matching } \\
\text { variables }\end{array}$ & 819 & 819 & 819 \\
\hline N & $0.07^{* * *}$ & $0.07^{* * *}$ & $0.07^{* * *}$ \\
\hline OLS with PS weighting & $0.05^{* * *}$ & $(0.01)$ & $(0.01)$ \\
\hline N & $(0.01)$ & 820 & 820 \\
\hline Nearest neighbour & 807 & $0.05^{* * *}$ & $0.05^{\star * *}$ \\
\hline & $0.06^{* * *}$ & $(0.01)$ & $(0.01)$ \\
\hline$N$ & $(0.02)$ & 807 & 807 \\
\hline
\end{tabular}

Robust standard errors in parentheses; * $p<0.1,{ }^{* *} p<0.05,{ }^{* * *} p<0.01$.

Table A4.2: Indicators of absorptive capacity

Part A

\begin{tabular}{|l|l|l|l|l|l|}
\hline & $\mathbf{1}$ & $\mathbf{2}$ & $\mathbf{3}$ & $\mathbf{4}$ & $\mathbf{5}$ \\
\hline & $\begin{array}{l}\text { Livelihood } \\
\text { diversity }\end{array}$ & $\begin{array}{l}\text { Livestock } \\
\text { diversity }\end{array}$ & Herd size & $\begin{array}{l}\text { Improved } \\
\text { drinking water }\end{array}$ & $\begin{array}{l}\text { Water for } \\
\text { livestock }\end{array}$ \\
\hline OLS regression & $0.09^{* *}$ & -0.00 & $0.09^{* *}$ & 0.06 & -0.01 \\
\hline$N$ & $(0.03)$ & $(0.04)$ & $(0.03)$ & $(0.04)$ & $(0.04)$ \\
\hline $\begin{array}{l}\text { OLS regression } \\
\text { with alternative } \\
\text { matching variables }\end{array}$ & 819 & 819 & 819 & 819 & 819 \\
\hline & $0.06^{*}$ & $0.07^{*}$ & $0.17^{* \star *}$ & 0.06 & 0.02 \\
\hline$N$ & $(0.03)$ & $(0.04)$ & $(0.04)$ & $(0.04)$ & $(0.04)$ \\
\hline $\begin{array}{l}\text { OLS with PS } \\
\text { weighting }\end{array}$ & 820 & 820 & 820 & 820 & 820 \\
\hline N & $0.08^{* \star *}$ & 0.00 & $0.09^{* \star *}$ & $0.06^{\star}$ & -0.01 \\
\hline Nearest neighbour & $(0.03)$ & $(0.04)$ & $(0.03)$ & $(0.04)$ & $(0.04)$ \\
\hline & 807 & 807 & 807 & 807 & 807 \\
\hline$N$ & $(0.05)$ & 0.04 & $0.09^{*}$ & 0.04 & -0.06 \\
\hline Robust standard & 807 & $(0.05)$ & $(0.05)$ & $(0.05)$ & $(0.05)$ \\
\hline
\end{tabular}

Robust standard errors in parentheses; ${ }^{*} p<0.1,{ }^{* *} p<0.05,{ }^{* * *} p<0.01$. 
Part B

\begin{tabular}{|l|l|l|l|l|l|}
\hline & $\mathbf{6}$ & $\mathbf{7}$ & $\mathbf{8}$ & $\mathbf{9}$ & $\mathbf{1 0}$ \\
\hline & $\begin{array}{l}\text { Awareness of } \\
\text { community } \\
\text { contingency } \\
\text { plan }\end{array}$ & $\begin{array}{l}\text { Access to } \\
\text { savings }\end{array}$ & $\begin{array}{l}\text { Access to early- } \\
\text { warning } \\
\text { information }\end{array}$ & $\begin{array}{l}\text { Access to back- } \\
\text { up food supplies }\end{array}$ & Dietary diversity \\
\hline OLS regression & $0.15^{\star *}$ & 0.01 & 0.06 & $0.10^{* *}$ & -0.02 \\
\hline$N$ & $(0.03)$ & $(0.03)$ & $(0.04)$ & $(0.04)$ & $(0.03)$ \\
\hline $\begin{array}{l}\text { OLS regression } \\
\text { with alternative } \\
\text { matching variables }\end{array}$ & 819 & 819 & 819 & 819 & 819 \\
\hline N & $0.17^{\star \star *}$ & -0.02 & $0.06^{*}$ & $0.12^{* \star *}$ & 0.00 \\
\hline$N$ & $(0.03)$ & $(0.03)$ & $(0.04)$ & $(0.04)$ & $(0.03)$ \\
\hline $\begin{array}{l}\text { OLS with PS } \\
\text { weighting }\end{array}$ & 820 & 820 & 820 & 820 & 820 \\
\hline & $0.15^{\star \star *}$ & -0.02 & 0.06 & $0.07^{\star *}$ & -0.02 \\
\hline$N$ & $(0.03)$ & $(0.03)$ & $(0.04)$ & $(0.04)$ & $(0.03)$ \\
\hline Nearest neighbour & $0.12^{\star \star *}$ & 807 & 807 & 807 & 807 \\
\hline & $(0.04)$ & -0.06 & 0.05 & $0.13^{* *}$ & 0.03 \\
\hline$N$ & 807 & $(0.05)$ & $(0.05)$ & $(0.05)$ & $(0.04)$ \\
\hline
\end{tabular}

Robust standard errors in parentheses; ${ }^{*} p<0.1,{ }^{* *} p<0.05,{ }^{* * *} p<0.01$.

Table A4.3: Indicators of adaptive capacity

\begin{tabular}{|l|l|l|l|l|}
\hline & $\mathbf{1}$ & $\mathbf{2}$ & $\mathbf{3}$ & $\mathbf{4}$ \\
\hline & $\begin{array}{l}\text { Remittances or } \\
\text { formal earnings }\end{array}$ & Access to credit & Education level & $\begin{array}{l}\text { Growth of } \\
\text { fruit/vegetables }\end{array}$ \\
\hline OLS regression & 0.01 & 0.05 & -0.02 & $0.08^{* *}$ \\
\hline$N$ & $(0.03)$ & $(0.03)$ & $(0.02)$ & $(0.03)$ \\
\hline $\begin{array}{l}\text { OLS regression } \\
\text { with alternative } \\
\text { matching variables }\end{array}$ & 819 & 819 & 819 & 819 \\
\hline N & 0.04 & $0.06^{*}$ & -0.03 & $0.10^{* \star *}$ \\
\hline $\begin{array}{l}\text { OLS with PS } \\
\text { weighting }\end{array}$ & $(0.03)$ & $(0.03)$ & $(0.02)$ & $(0.03)$ \\
\hline & 0.01 & 820 & 820 & 820 \\
\hline$N$ & $(0.03)$ & $0.07^{* *}$ & -0.02 & $0.07^{* *}$ \\
\hline Nearest neighbour & 807 & $(0.03)$ & $(0.02)$ & $(0.03)$ \\
\hline & $0.08^{*}$ & 807 & 807 & 807 \\
\hline$N$ & $(0.04)$ & $0.09^{* *}$ & -0.04 & $0.10^{* *}$ \\
\hline & 807 & $(0.05)$ & $(0.03)$ & $(0.04)$ \\
\hline
\end{tabular}

\begin{tabular}{|l|l|l|l|}
\hline & $\mathbf{5}$ & $\mathbf{6}$ & $\mathbf{7}$ \\
\hline OLS regression & Access to markets & $\begin{array}{l}\text { Disputes over } \\
\text { resources }\end{array}$ & Productive assets \\
\hline$N$ & 0.06 & -0.01 & $0.07^{*}$ \\
\hline $\begin{array}{l}\text { OLS regression } \\
\text { with alternative } \\
\text { matching variables }\end{array}$ & $0.03)$ & $(0.02)$ & $(0.03)$ \\
\hline N & $0.11^{* *}$ & 819 & 819 \\
\hline $\begin{array}{l}\text { OLS with PS } \\
\text { weighting }\end{array}$ & $(0.03)$ & 0.00 & $0.08^{\star *}$ \\
\hline N & $0.05^{\star}$ & $(0.02)$ & $(0.04)$ \\
\hline Nearest neighbour & 0.07 & 820 & 820 \\
\hline & $(0.05)$ & -0.01 & $0.08^{\star *}$ \\
\hline$N$ & 807 & $(0.02)$ & $(0.04)$ \\
\hline
\end{tabular}

Robust standard errors in parentheses; ${ }^{*} p<0.1,{ }^{* *} p<0.05,{ }^{* * *} p<0.01$. 
Table A4.4: Indicators of transformative capacity

\begin{tabular}{|l|l|l|l|l|l|}
\hline & $\mathbf{1}$ & $\mathbf{2}$ & $\mathbf{3}$ & $\mathbf{4}$ & $\mathbf{5}$ \\
\hline & $\begin{array}{l}\text { Attitude to } \\
\text { change }\end{array}$ & $\begin{array}{l}\text { Adoption of } \\
\text { innovative } \\
\text { practices }\end{array}$ & $\begin{array}{l}\text { Involvement in } \\
\text { CDMC }\end{array}$ & $\begin{array}{l}\text { Capacity of } \\
\text { CDMC }\end{array}$ & $\begin{array}{l}\text { Participation in } \\
\text { groups }\end{array}$ \\
\hline OLS regression & 0.05 & $0.20^{* *}$ & $0.09^{* * *}$ & $0.17^{* *}$ & 0.04 \\
\hline$N$ & $(0.03)$ & $(0.04)$ & $(0.03)$ & $(0.03)$ & $(0.03)$ \\
\hline $\begin{array}{l}\text { OLS regression } \\
\text { with alternative } \\
\text { matching variables }\end{array}$ & 819 & 819 & 819 & 819 & 819 \\
\hline N & 0.04 & $0.21^{\star \star *}$ & $0.12^{\star \star *}$ & $0.20^{\star \star *}$ & 0.04 \\
\hline$N$ & $(0.03)$ & $(0.04)$ & $(0.03)$ & $(0.03)$ & $(0.03)$ \\
\hline $\begin{array}{l}\text { OLS with PS } \\
\text { weighting }\end{array}$ & 820 & 820 & 820 & 820 & 820 \\
\hline N & 0.03 & $0.21^{\star * *}$ & $0.09^{\star \star *}$ & $0.16^{\star \star *}$ & 0.03 \\
\hline Nearest neighbour & 0.01 & $(0.04)$ & $(0.03)$ & $(0.03)$ & $(0.03)$ \\
\hline & $(0.05)$ & 807 & 807 & 807 & 807 \\
\hline$N$ & 807 & $0.21^{* * *}$ & 0.05 & $0.13^{\star *}$ & 0.01 \\
\hline
\end{tabular}

\begin{tabular}{|c|c|c|c|c|}
\hline & 6 & 7 & 8 & 9 \\
\hline & $\begin{array}{l}\text { Voice of women } \\
\text { in the } \\
\text { community }\end{array}$ & $\begin{array}{l}\text { Integration of } \\
\text { community } \\
\text { plans }\end{array}$ & $\begin{array}{l}\text { Ability to make } \\
\text { complaints }\end{array}$ & $\begin{array}{l}\text { Voice of } \\
\text { disabled in the } \\
\text { community }\end{array}$ \\
\hline \multirow[t]{2}{*}{ OLS regression } & 0.02 & 0.05 & 0.04 & $0.08^{*}$ \\
\hline & $(0.03)$ & $(0.02)$ & $(0.04)$ & $(0.04)$ \\
\hline$N$ & 819 & 819 & 819 & 819 \\
\hline \multirow{2}{*}{$\begin{array}{l}\text { OLS regression } \\
\text { with alternative } \\
\text { matching variables }\end{array}$} & -0.02 & $0.05^{* *}$ & 0.04 & $0.08^{* *}$ \\
\hline & $(0.03)$ & $(0.02)$ & $(0.04)$ & $(0.04)$ \\
\hline$N$ & 820 & 820 & 820 & 820 \\
\hline \multirow{2}{*}{$\begin{array}{l}\text { OLS with PS } \\
\text { weighting }\end{array}$} & 0.01 & 0.03 & 0.03 & $0.06^{*}$ \\
\hline & $(0.03)$ & $(0.03)$ & $(0.04)$ & $(0.04)$ \\
\hline$N$ & 807 & 807 & 807 & 807 \\
\hline \multirow[t]{2}{*}{ Nearest neighbour } & 0.05 & -0.01 & $0.11^{* *}$ & 0.06 \\
\hline & $(0.05)$ & $(0.04)$ & $(0.05)$ & $(0.05)$ \\
\hline$N$ & 807 & 807 & 807 & 807 \\
\hline
\end{tabular}

Robust standard errors in parentheses; ${ }^{*} p<0.1,{ }^{* *} p<0.05,{ }^{* * *} p<0.01$

Table A4.5: Wealth

\begin{tabular}{|l|l|l|}
\hline & $\mathbf{1}$ & $\mathbf{2}$ \\
\hline & Normalized wealth index & $\begin{array}{l}\text { Difference in normalized } \\
\text { wealth index }\end{array}$ \\
\hline OLS regression & 0.06 & 0.05 \\
\hline & $(0.06)$ & $(0.05)$ \\
\hline$N$ & 819 & 819 \\
\hline $\begin{array}{l}\text { OLS regression with alternative } \\
\text { matching variables }\end{array}$ & -0.13 & -0.02 \\
\hline & $(0.09)$ & $(0.05)$ \\
\hline$N$ & 820 & 820 \\
\hline OLS with PS weighting & 0.06 & 0.04 \\
\hline & $(0.05)$ & $(0.05)$ \\
\hline$N$ & 807 & 807 \\
\hline Nearest neighbour & 0.00 & -0.01 \\
\hline & $(0.12)$ & $(0.08)$ \\
\hline$N$ & 807 & 807 \\
\hline
\end{tabular}

Robust standard errors in parentheses; ${ }^{*} p<0.1,{ }^{* *} p<0.05,{ }^{* * *} p<0.01$. 
Table A4.6: Groups

\begin{tabular}{|l|l|l|}
\hline & $\mathbf{1}$ & $\mathbf{2}$ \\
\hline & $\begin{array}{l}\text { Household member(s) } \\
\text { participate in any } \\
\text { community groups }\end{array}$ & $\begin{array}{l}\text { Number of community } \\
\text { groups in which } \\
\text { household participates }\end{array}$ \\
\hline OLS regression & 0.02 & 0.02 \\
\hline N & $(0.03)$ & $(0.08)$ \\
\hline $\begin{array}{l}\text { OLS regression with alternative } \\
\text { matching variables }\end{array}$ & 819 & 819 \\
\hline & 0.04 & 0.06 \\
\hline$N$ & $(0.04)$ & $(0.09)$ \\
\hline OLS with PS weighting & 820 & 820 \\
\hline & -0.00 & -0.01 \\
\hline$N$ & $(0.03)$ & $(0.08)$ \\
\hline Nearest neighbour & 807 & 807 \\
\hline & -0.03 & -0.18 \\
\hline$N$ & $(0.05)$ & $(0.16)$ \\
\hline
\end{tabular}

Robust standard errors in parentheses; * $p<0.1,{ }^{* *} p<0.05,{ }^{* * *} p<0.01$.

Table A4.7: Livestock

\begin{tabular}{|l|l|l|l|l|l|}
\hline & $\mathbf{1}$ & $\mathbf{2}$ & $\mathbf{3}$ & $\mathbf{4}$ & $\mathbf{5}$ \\
\hline & $\begin{array}{l}\text { Household } \\
\text { owns any } \\
\text { livestock }\end{array}$ & $\begin{array}{l}\text { Number of types } \\
\text { of animals } \\
\text { owned }\end{array}$ & $\begin{array}{l}\text { Women mainly } \\
\text { responsible for } \\
\text { any types of } \\
\text { animal }\end{array}$ & $\begin{array}{l}\text { Number of } \\
\text { animal types for } \\
\text { which women } \\
\text { were mainly } \\
\text { responsible }\end{array}$ & $\begin{array}{l}\text { Proportion of } \\
\text { animal types for } \\
\text { which women } \\
\text { were mainly } \\
\text { responsible }\end{array}$ \\
\hline OLS regression & $0.09^{* *}$ & 0.08 & 0.01 & 0.04 & -0.01 \\
\hline N & $(0.03)$ & $(0.08)$ & $(0.03)$ & $(0.04)$ & $(0.02)$ \\
\hline $\begin{array}{l}\text { OLS regression } \\
\text { with alternative } \\
\text { matching variables }\end{array}$ & 819 & 819 & 819 & 819 & 591 \\
\hline N & $0.15^{\star * *}$ & $0.27^{\star * *}$ & 0.00 & 0.03 & -0.02 \\
\hline $\begin{array}{l}\text { OLS with PS } \\
\text { weighting }\end{array}$ & $(0.03)$ & $(0.09)$ & $(0.02)$ & $(0.04)$ & $(0.02)$ \\
\hline & $0.08^{\star * *}$ & 0.10 & 820 & 820 & 592 \\
\hline$N$ & $(0.03)$ & $(0.09)$ & 0.01 & 0.04 & -0.01 \\
\hline Nearest neighbour & 807 & 807 & $(0.03)$ & $(0.04)$ & $(0.02)$ \\
\hline & $0.08^{*}$ & 0.08 & 807 & 807 & 583 \\
\hline$N$ & $(0.05)$ & $(0.15)$ & 0.00 & 0.03 & -0.01 \\
\hline
\end{tabular}

Robust standard errors in parentheses; ${ }^{*} p<0.1,{ }^{* *} p<0.05,{ }^{* * *} p<0.01$. 
Table A4.8: Crops

\begin{tabular}{|c|c|c|c|c|}
\hline & 1 & 2 & 3 & 4 \\
\hline & $\begin{array}{l}\text { Household grew } \\
\text { any crops in the } \\
\text { past year }\end{array}$ & $\begin{array}{l}\text { Number of types of } \\
\text { cereal crops the } \\
\text { household grew in } \\
\text { the past year }\end{array}$ & $\begin{array}{l}\text { Number of types of } \\
\text { non-cereal crops } \\
\text { the household } \\
\text { grew in the past } \\
\text { year }\end{array}$ & $\begin{array}{l}\text { Number of acres } \\
\text { the household } \\
\text { owns }\end{array}$ \\
\hline \multirow[t]{2}{*}{ OLS regression } & $0.09^{* *}$ & $0.12^{* *}$ & $0.17^{* *}$ & $0.24^{* *}$ \\
\hline & $(0.03)$ & $(0.04)$ & $(0.06)$ & $(0.08)$ \\
\hline$N$ & 819 & 819 & 819 & 819 \\
\hline \multirow{2}{*}{$\begin{array}{l}\text { OLS regression } \\
\text { with alternative } \\
\text { matching variables }\end{array}$} & $0.13^{\star \star \star}$ & $0.18^{\star \star \star}$ & $0.22^{\star \star \star}$ & $0.31^{\star \star \star}$ \\
\hline & $(0.03)$ & $(0.04)$ & $(0.06)$ & $(0.09)$ \\
\hline$N$ & 820 & 820 & 820 & 820 \\
\hline \multirow{2}{*}{$\begin{array}{l}\text { OLS with PS } \\
\text { weighting }\end{array}$} & $0.09^{\star \star \star}$ & $0.13^{\star \star \star}$ & $0.18^{* \star \star}$ & $0.25^{\star * \star}$ \\
\hline & $(0.03)$ & $(0.04)$ & $(0.06)$ & $(0.08)$ \\
\hline$N$ & 807 & 807 & 807 & 807 \\
\hline \multirow[t]{2}{*}{ Nearest neighbour } & $0.12^{\star \star \star}$ & $0.15^{\star \star}$ & $0.21^{* \star *}$ & $0.21^{*}$ \\
\hline & $(0.05)$ & $(0.06)$ & $(0.08)$ & $(0.12)$ \\
\hline$N$ & 807 & 807 & 807 & 807 \\
\hline
\end{tabular}

Table A4.9: Off-farm activities

\begin{tabular}{|l|l|l|l|}
\hline & $\mathbf{1}$ & $\mathbf{2}$ & $\mathbf{3}$ \\
\hline & $\begin{array}{l}\text { Household } \\
\text { engaged in any } \\
\text { non-farm income- } \\
\text { generating } \\
\text { activities in the } \\
\text { past 12 months }\end{array}$ & $\begin{array}{l}\text { Number of non- } \\
\text { farm income- } \\
\text { generating } \\
\text { activities that the } \\
\text { household } \\
\text { engaged in }\end{array}$ & $\begin{array}{l}\text { Female household } \\
\text { member engaged } \\
\text { in any non-farm } \\
\text { income-generating } \\
\text { activities }\end{array}$ \\
\hline OLS regression & $0.09^{* *}$ & $0.10^{* *}$ & $0.08^{*}$ \\
\hline$N$ & $(0.03)$ & $(0.04)$ & $(0.03)$ \\
\hline $\begin{array}{l}\text { OLS regression } \\
\text { with alternative } \\
\text { matching variables }\end{array}$ & 819 & 819 & 819 \\
\hline N & $0.06^{*}$ & 0.06 & 0.05 \\
\hline $\begin{array}{l}\text { OLS with PS } \\
\text { weighting }\end{array}$ & $(0.03)$ & $(0.04)$ & $(0.03)$ \\
\hline N & $0.08^{* * *}$ & 820 & 820 \\
\hline Nearest neighbour & $0.09^{*}$ & $0.09^{* * *}$ & $0.07^{* *}$ \\
\hline & $(0.05)$ & $(0.03)$ & $(0.03)$ \\
\hline$N$ & 807 & 807 & 807 \\
\hline
\end{tabular}

Robust standard errors in parentheses; * $p<0.1,{ }^{* *} p<0.05,{ }^{* * *} p<0.01$.

In general, these robustness checks support the main results. Even if the coefficient is no longer statistically significant, there are only a few instances when the sign on the coefficient differs from what was presented in Section 6, and these cases do not apply to the headline results. The nearest neighbour matching algorithm seems to cause the most change to the results. 


\section{BIBLIOGRAPHY}

A. Abadie and G. W. Imbens, On the failure of the bootstrap for matching estimators, Econometric, vol. 76 (2008), pages 1537-1557.

Marco Caliendo and Sabine Kopeinig, Some Practical Guidance for the Implementation of Propensity Score Matching, Journal of Economic Surveys, vol. 22(1) (2008), pages 31-72.

Martin Bland and Douglas G. Altman, Statistics notes: Cronbach's alpha, British Medical Journal, (1997).

Deon Filmer and Lant H. Pritchett, Estimating Wealth Effects without Expenditure Data - Or Tears: An Application to Educational Enrollments in States of India, Demography, vol. 38(1) (2001), pages 115-132.

James J. Heckman, Robert J. LaLonde and Jeffrey A. Smith, The Economics and Econometrics of Active Labor Market Programs, Handbook of Labor Economics, vol. 3, part A (1999), pages 1865-2097.

Keisuke Hirano and Guido W. Imbens, Estimation of Causal Effects using Propensity Score Weighting: An Application to Data on Right Heart Catheterization, Health Services \& Outcomes Research Methodology, vol. 2 (2001), pages 259-278.

Paul R. Rosenbaum and Donald B. Rubin, The Central Role of the Propensity Score in Observational Studies for Causal Effects, Biometrika, vol. 70(1) (1983), pages 41-55.

Donald B. Rubin, Using Propensity Scores to Help Design Observational Studies: Application to the Tobacco Litigation, Health Services \& Outcomes Research Methodology, vol. 2(3) (2001), pages 169-188. 
1 In the first two phases of the La Nina programme, the consortium included Vétérinaires Sans Frontières (VSF)-Suisse, Vétérinaires Sans Frontières (VSF)-Belgium, but they were not consortium members during the third and fourth phases on which this evaluation focuses. In the fifth phase of the programme, the planning for which began in April 2015, Transparency International also joined the consortium.

2 If no answer is given by a particular consortium partner within 24 hours, their feedback would not be taken into consideration. This maintains the incentive for speedy responses to the proposals.

3 For example, if 40 households are required from the community as a whole, and the community contains 100 households in total, 10 of which are in 'half' $A$ and 90 of which are in 'half' $B, 4$ households should be taken from 'half' $A$ and 36 households should be taken from 'half' $B(40 * 10 / 100=4 ; 60 * 90 / 100=$ 36).

4 The number of stones placed on the floor was equal to the sampling interval for that 'half' of the community.

5 This arises due to 'classical measurement error', which attenuates effect sizes - including for basic ttests - towards zero.

6 This approach is described in 'A Multidimensional Approach to Measuring Resilience', Oxfam GB working paper, August 2013: http://policy-practice.oxfam.org.uk/publications/a-multidimensionalapproach-to-measuring-resilience-302641.

7 'The Future is a Choice: The Oxfam Framework and Guidance for Resilient Development' can be downloaded here: http://policy-practice.oxfam.org.uk/publications/the-future-is-a-choice-the-oxfamframework-and-guidance-for-resilient-developme-604990.

8 Specifically, focus group discussions were carried out in Chok Chok village, approximately $20 \mathrm{~km}$ from Lodwar in Turkana Central.

9 Full details of the CoBRA project in Turkana can be found in 'Understanding Community Resilience: Findings from Community-Based Resilience Analysis (CoBRA) Assessments - Marsabit, Turkana and Kajiado counties, Kenya and Karamoja sub-region, Uganda':

http://www.undp.org/content/dam/undp/library/Environment\%20and\%20Energy/sustainable\%20land\%2 2management/CoBRA/CoBRA_Assessments_Report.pdf.

10 It should be noted that, if the capacities are first weighted equally, each additional indicator added to a capacity is effectively down-weighted in the resulting resilience index.

11 In fact, since we use some version of the arithmetic mean to create the overall resilience indices, all of the characteristics and, indeed, all of the capacities are effectively perfect substitutes (in the economic sense).

12 This follows the guidance in Filmer and Pritchett (2001). The first principal component captures sufficient variation in the data.

13 To do this, we subtract the mean of the wealth index, and then divide by its standard deviation.

14 These results present something similar to a Difference-in-Differences specification. However, the baseline data is recalled rather than measured at baseline.

15 We elected not to cluster our standard errors at the community level because this would result in a small number of clusters and would be likely to bias our standard errors downwards.

16 It should be noted that, for all these regression techniques, we report robust standard errors. However, the standard errors are not bootstrapped as in the main results in Section 6.

$17 \mathrm{We}$ are able to test whether the covariates are distributed sufficiently similarly for the intervention and comparison group using Rubin's (2001) tests. For the matching variables used in this report, with the kernel matching algorithm, Rubin's $B=24.0$, and Rubin's $R=1.41$. According to Rubin's recommendations, this suggests that the covariates are sufficiently balanced for OLS regression methods to be valid.

18 Choosing whether to match with and without replacement involves a trade-off between bias and variance. If we allow replacement, the average quality of matching will increase and the bias will decrease, especially when the distribution of the propensity score is very different in the intervention and comparison group. However, allowing for replacement increases the variance of the estimates because, in effect, the number of distinct comparison observations is reduced (Caliendo and Kopeinig, 2008).

19 Following the guidance of Abadie and Imbens (2008), we calculate robust standard errors analytically using the teffects module in Stata. These standard errors are not bootstrapped. 
For more information, or to comment on this report, email policyandpractice@oxfam.org.uk

(C) Oxfam GB May 2018

This publication is copyright but the text may be used free of charge for the purposes of advocacy, campaigning, education, and research, provided that the source is acknowledged in full. The copyright holder requests that all such use be registered with them for impact assessment purposes. For copying in any other circumstances, or for re-use in other publications, or for translation or adaptation, permission must be secured and a fee may be charged. Email policyandpractice@oxfam.org.uk.

The information in this publication is correct at the time of going to press.

ISBN: 978-1-78748-248-7

DOI: $10.21201 / 2018.2487$

Oxfam GB, Oxfam House, John Smith Drive, Cowley, Oxford, OX4 2JY, UK.

\section{OXFAM}

Oxfam is an international confederation of 20 organizations networked together in more than 90 countries, as part of a global movement for change, to build a future free from the injustice of poverty. Please write to any of the agencies for further information, or visit www.oxfam.org.

Oxfam America (www.oxfamamerica.org)

Oxfam Australia (www.oxfam.org.au)

Oxfam-in-Belgium (www.oxfamsol.be)

Oxfam Brasil (www.oxfam.org.br)

Oxfam Canada (www.oxfam.ca)

Oxfam France (www.oxfamfrance.org)

Oxfam Germany (www.oxfam.de)

Oxfam GB (www.oxfam.org.uk)

Oxfam Hong Kong (www.oxfam.org.hk)

Oxfam IBIS (Denmark) (http://oxfamibis.dk/)

Oxfam India (www.oxfamindia.org)

Oxfam Intermón (Spain) (www.oxfamintermon.org)

Oxfam Ireland (www.oxfamireland.org)

Oxfam Italy (www.oxfamitalia.org)

Oxfam Japan (www.oxfam.jp)

Oxfam Mexico (www.oxfammexico.org)

Oxfam New Zealand (www.oxfam.org.nz)

Oxfam Novib (Netherlands) (www.oxfamnovib.nl)

Oxfam Québec (www.oxfam.qc.ca)

Oxfam South Africa (http://www.oxfam.org.za/) 